\title{
The contribution of citizen rescuers to survival after out-of-hospital cardiac arrest
}

Citation for published version (APA):

Pijls, R. W. M. (2019). The contribution of citizen rescuers to survival after out-of-hospital cardiac arrest. [Doctoral Thesis, Maastricht University]. ProefschriftMaken. https://doi.org/10.26481/dis.20191129rp

Document status and date:

Published: 01/01/2019

DOI:

10.26481/dis.20191129rp

Document Version:

Publisher's PDF, also known as Version of record

\section{Please check the document version of this publication:}

- A submitted manuscript is the version of the article upon submission and before peer-review. There can be important differences between the submitted version and the official published version of record.

People interested in the research are advised to contact the author for the final version of the publication, or visit the DOI to the publisher's website.

- The final author version and the galley proof are versions of the publication after peer review.

- The final published version features the final layout of the paper including the volume, issue and page numbers.

Link to publication

\footnotetext{
General rights rights.

- You may freely distribute the URL identifying the publication in the public portal. please follow below link for the End User Agreement:

www.umlib.nl/taverne-license

Take down policy

If you believe that this document breaches copyright please contact us at:

repository@maastrichtuniversity.nl

providing details and we will investigate your claim.
}

Copyright and moral rights for the publications made accessible in the public portal are retained by the authors and/or other copyright owners and it is a condition of accessing publications that users recognise and abide by the legal requirements associated with these

- Users may download and print one copy of any publication from the public portal for the purpose of private study or research.

- You may not further distribute the material or use it for any profit-making activity or commercial gain

If the publication is distributed under the terms of Article $25 \mathrm{fa}$ of the Dutch Copyright Act, indicated by the "Taverne" license above, 


\section{Ruud Pijls}

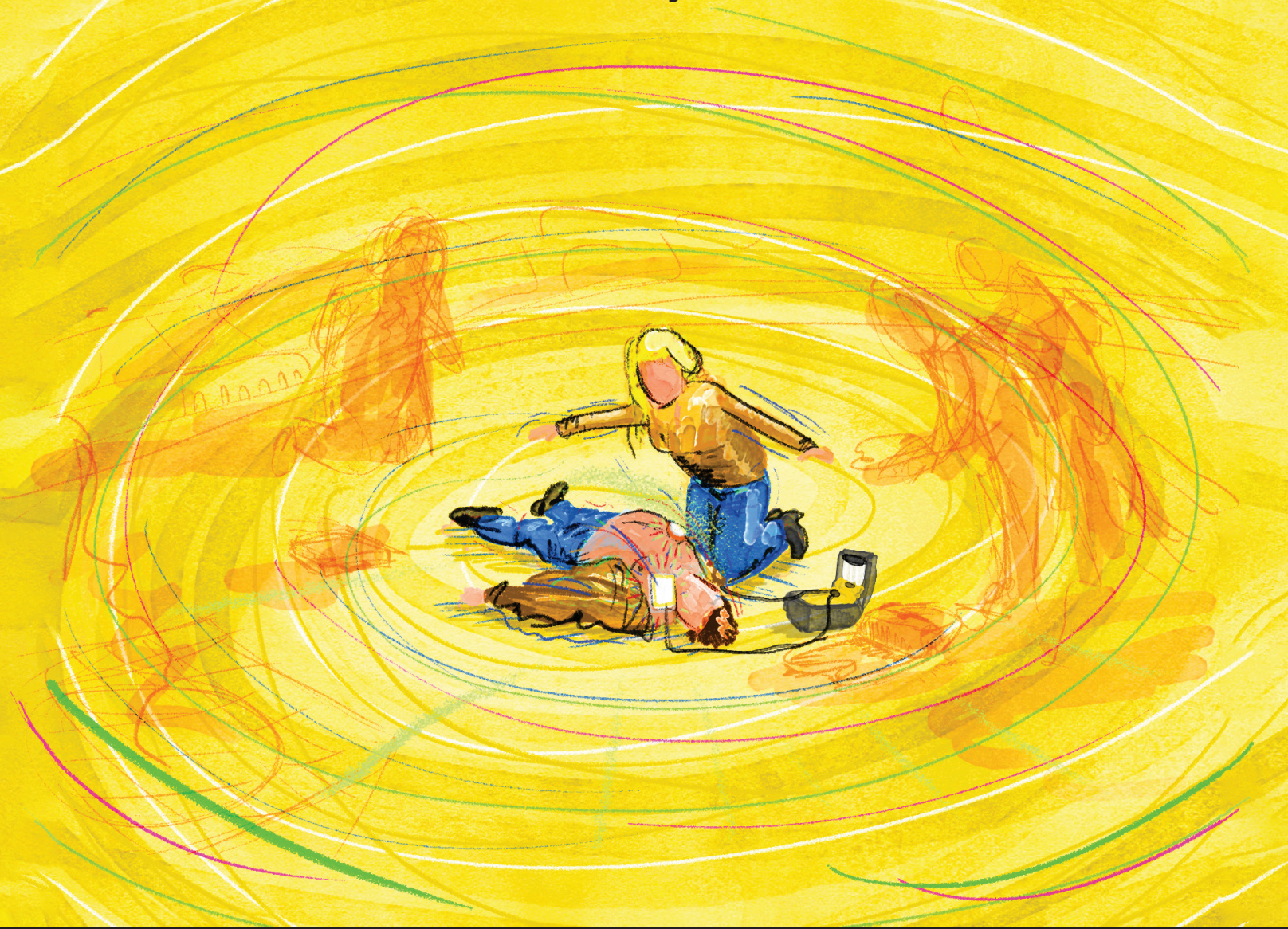

\section{THE CONTRIBUTION OF CITIZEN RESCUERS TO SURVIVAL AFTER OUT-OF-HOSPITAL CARDIAC ARREST}




\title{
The contribution of citizen rescuers to survival after out-of-hospital cardiac arrest
}

\author{
Ruud Pijls
}


The contribution of citizen rescuers to survival after out-of-hospital cardiac arrest

PhD thesis, Maastricht University, The Netherlands

Copyright (C) Ruud W.M. Pijls, Maastricht, The Netherlands

All rights are reserved. No parts of this book may be reproduced in any form without written permission of the author.

The research described in this thesis was supported by the Province Limburg [SAS-20201794] and the Mercurius Foundation [30957210N].

Financial support by the Dutch Heart Foundation for the publication of this thesis is gratefully acknowledged.

Financial support for the printing of this thesis was provided by RESCAR and is gratefully acknowledged.

Printed by www.proefschriftmaken.nl

Cover design Niek Gooren

Layout www.proefschriftmaken.nl

ISBN 978-94-6380-594-0 


\title{
The contribution of citizen rescuers to survival after out-of-hospital cardiac arrest
}

\author{
Proefschrift \\ ter verkrijging van de graad van doctor aan de Universiteit Maastricht, \\ op gezag van de Rector Magnificus, Prof.dr. Rianne M. Letschert \\ volgens het besluit van het College van Decanen, \\ in het openbaar te verdedigen \\ op vrijdag 29 november 2019 om 12:00 uur
}

door

Ruud Wilhelmus Maria Pijls

Geboren op 27 januari 1985, te Roermond, Nederland 


\section{Promotor}

Prof. dr. A.P.M. Gorgels

\section{Copromotor}

Dr. P.J. Nelemans

\section{Beoordelingscommissie}

Prof. dr. H.J.G.M. Crijns (voorzitter)

Dr. R.W. Koster (Universiteit van Amsterdam)

Prof. dr. K. Monsieurs (Universiteit Antwerpen, België)

Prof. dr. P.G.A. Volders

Prof. dr. N.K. de Vries 


\section{Table of contents}

Chapter 1 General introduction 9

Chapter 2 A text message alert system for trained volunteers improves out-of-hospital cardiac arrest survival

Chapter 3 Factors modifying performance of a novel citizen text message alert system in improving survival of out-of-hospital cardiac arrest

Chapter 4 Circumstances and causes of sudden circulatory arrests in the Dutch province of Limburg and the involvement of citizen rescuers

Chapter 5 Characteristics of a novel citizen rescue system for out-of-hospital cardiac arrest in the Dutch province of Limburg: relation to incidence and survival

Chapter 6 General discussion

Chapter 7 Samenvatting

Summary

Valorisation

Dankwoord

About the author 

The line between life or death is determined by what we are willing to do 〜Bear Grylls 

Chapter 1

General introduction 


\section{Introduction}

In industrialised countries sudden out-of-hospital circulatory arrest (OHCA) is an important public health problem ${ }^{1,2}$ largely caused by cardiac disease. ${ }^{3}$ Reported survival rates are low $(<10 \%)^{4,5}$ and have not improved significantly in many countries over the last 30 years. ${ }^{6}$ By the advent of several recent developments, realistic opportunities for lay people have become available to increase survival after OHCA: 1) the improvement of cardiopulmonary resuscitation techniques, such as chest compressions and mouth to mouth ventilation; 2) the availability of automated external defibrillators (AED) in the public domain and 3) the organisation of first responder systems such as the involvement of police officers and firefighters or community responders.

\section{Cardiopulmonary resuscitation}

Cardiopulmonary resuscitation (CPR) as it is, was established in the early 1960's, consisting of mouth to mouth ventilation ${ }^{7}$ and chest compressions. ${ }^{8-10}$ Over the years, due to scientific research and insight, the emphasis has changed from ventilation to chest compressions. ${ }^{11}$ The latter indeed is crucial to sustain blood flow to vital organs. Current European Resuscitation Council and other international guidelines recommend to start CPR with chest compressions ${ }^{12}$, to increase chest compressions/ventilation ratio from 15:2 to 30:2 and to increase the rate and depth of chest compressions compared to their 2005 and 2010 guidelines. ${ }^{13-15}$

\section{Automated external defibrillator}

Knowledge that cardiac arrest frequently was due to ventricular fibrillation and that this lethal arrhythmia could be reversed by an electrical counter shock led to the development of the defibrillator in $1957 .{ }^{10}$ Initial implementation of the defibrillator in hospitals stimulated the institution of coronary care units; later also ambulances were equipped with these devices and the paramedics were authorised to use them. However, it remained problematic that the time between onset of the arrival and the time of the lifesaving shock was too long due to the frequent long arrival times of the ambulance. Automating the defibrillators enabled lay persons to safely shock a fibrillating heart. The placement of AEDs in the public domain rapidly led to reports on successful resuscitation attempts in public places equipped with AEDs. ${ }^{16-18}$ 


\section{First responders systems}

Because it was found that the large majority of OHCAs occurred in residential areas ${ }^{1}$, soon programs were developed to implement AEDs in that setting. A widely used strategy is the involvement of first responders. First responders are defined as those responders that are active in a system or network that is set up to deliver semi-professional care in case of an OHCA. Frequently it regards police officers and firefighters or community responders (citizen rescuers), who are actively deployed to arrive as one of the first at the scene.

\section{Police officers and firefighters}

In the Netherlands both police officers and firefighters can be directed to an OHCA, some of their vehicles are equipped with AEDs and personnel is trained to apply basic life support (BLS), including the use of the AED. ${ }^{19}$ In case they are the first to arrive at the OHCA location they start resuscitation. In case the ambulance arrives first at the OHCA location the first responders assist the paramedics as needed. In a controlled clinical trial from the Netherlands where AEDs were used by police officers an increase in return of spontaneous circulation and admission to hospital of OHCA patients was reported but no significant increase in survival to hospital discharge. ${ }^{19}$ However, a recent meta-analysis showed implementation of police AED programs was associated with a decrease in the time to defibrillation and an increase of survival. ${ }^{20}$

\section{First community responder initiatives}

Around $50-70 \%$ of the OHCAs occur in the home situation. ${ }^{1}$ Therefore, improving survival of OHCA requires new innovative strategies. To compensate for delayed ambulance arrival times, first community responder systems were implemented in several countries. With the widespread availability of mobile phones, strategies were developed enabling notification of community responders close to the victim. In Sweden (Stockholm) a system, called Mobile Life Service (MLS), is used as a strategy to involve community responders to improve survival of OHCA. ${ }^{21}$ In case of an OHCA the position of all MLS users is determined and those users being within a radius of 500 meters of the OHCA are dispatched by a text message conveying information about the OHCA location. Although the system significantly increased the rate of bystander initiated CPR the effect on 30-day survival was small and not significant ${ }^{22}$; survival in the control group was $8.6 \%$ whereas survival in the intervention group was $11.2 \%$. A similar working app for dispatching community responders is Pulsepoint. ${ }^{23}$ There are currently no data about the effect of this system on the survival of OHCA.

In England, Australia, New Zealand, India, USA, Brazil, South Africa and parts of Europe the GoodSam app is used as a community responder strategy. ${ }^{24}$ Trained citizens nearby an OHCA can be alerted in this app-based system. The community responders are not only notified by the dispatch centre but can also be notified by bystanders of the OHCA if they have installed 
the GoodSAM app. It has not been studied yet whether the GoodSam program leads to increased survival.

In some counties in Sweden both police officers and firefighters are deployed in case of OHCA. The police is notified by a telephone call. The fire brigade automatically receives a notification and dispatches up to five firefighters. The deployment of these first responders was associated with a small but significantly increased 30 -day survival of OHCA from $7.7 \%$ to $9.5 \% .{ }^{25}$

\section{Community responder system in the Netherlands}

In a number of regions in the Netherlands, a novel system was introduced where citizen volunteers, who were trained in performing basic life support (BLS) and using an AED, are notified by the emergency medical services (EMS) dispatch centre. A network consisting of text message (TM) volunteers (community responders) and AEDs placed in residential areas was developed to reduce the delay in response time to start BLS. If EMS are called for (suspected) OHCA, the professional procedure throughout the Netherlands consists of dispatching two ambulances to the scene. Each vehicle has advanced life support equipment and is manned by one paramedic and a driver with CPR skills. First responders (mostly police officers) are notified only if they are already in close range of the circulatory arrest case. Community responders are notified by the dispatch centre, using the zip code derived location of the victim and the registered zip code of the community responders. In a suspected OHCA, the dispatcher activates the system simultaneously with the two ambulances. Zip code identified community responders within a radius of $1 \mathrm{~km}(0.62 \mathrm{mi})$ of the victim receive a TM, directing them to the scene to either start BLS (1:3 of notifications) or to get a nearest network AED first (2:3).

\section{Aim and outline of the thesis}

Although the community responder system was already implemented in a number of regions in the Netherlands, it was not known whether the system had any effect (positive or negative) on the survival of OHCA. Furthermore, because of the involvement of volunteers, the investment of installing AEDs in residential areas and the notification systems in the respective dispatch centres, there was a need for evaluating the benefit of this endeavour regarding outcomes of the victims, the burden to the rescuers and the efficiency and effectiveness of the system. These considerations prompted the execution of this thesis were I studied different aspects of the system.

Chapter 2 addresses the first and most important question, whether the system improves survival at hospital discharge in victims of an OHCA due to a cardiac cause. Chapter 3 evaluates whether the performance of the system is modified by factors which affect delay between onset of OHCA and start of resuscitation. Factors being evaluated are witnessed versus 
non-witnessed OHCA, whether the location of the OHCA is at home or outside the home, arrival time of the first ambulance at the OHCA location and whether the OHCA occurred during the day or evening/night. Chapter 4 describes circumstances and causes of OHCAs to verify whether the alert system is deployed in conditions for which it was initially developed, specifically where the community responders are involved. Chapter 5 gives an estimate of the incidence of OHCA and provides answers to questions such as: how frequent is the system activated in case of OHCA and if the system is not activated what are potential reasons for not doing so? How frequent is the system activated in non-OHCAs? How frequent are volunteers notified, and is volunteer density related to survival? 


\section{References}

1. de Vreede-Swagemakers JJ, Gorgels AP, Dubois-Arbouw WI, et al. Out-of-hospital cardiac arrest in the 1990's: a population-based study in the Maastricht area on incidence, characteristics and survival. J Am Coll Cardiol. 1997;30:1500-5.

2. Berdowski J, Berg RA, Tijssen JG and Koster RW. Global incidences of out-of-hospital cardiac arrest and survival rates: Systematic review of 67 prospective studies. Resuscitation. 2010;81:1479-87.

3. Zipes DP and Wellens HJ. Sudden cardiac death. Circulation. 1998;98:2334-51.

4. Waalewijn RA, de Vos R and Koster RW. Out-of-hospital cardiac arrests in Amsterdam and its surrounding areas: results from the Amsterdam resuscitation study (ARREST) in 'Utstein' style. Resuscitation. 1998;38:157-67.

5. Hasselqvist-Ax I, Riva G, Herlitz J, et al. Early cardiopulmonary resuscitation in out-of-hospital cardiac arrest. N Engl J Med. 2015;372:2307-15.

6. Sasson C, Rogers MA, Dahl J and Kellermann AL. Predictors of survival from out-of-hospital cardiac arrest: a systematic review and meta-analysis. Circ Cardiovasc Qual Outcomes. 2010;3:63-81.

7. Sands RP, Jr. and Bacon DR. An inventive mind: the career of James O. Elam, M.D. (1918-1995). Anesthesiology. 1998;88:1107-12.

8. Trubuhovich RV. History of Mouth-to-Mouth Rescue Breathing. Part 1. Crit Care Resusc. 2005;7:257.

9. Trubuhovich RV. History of mouth-to-mouth rescue breathing. Part 2: the 18th century. Crit Care Resusc. 2006;8:157-71.

10. Acosta P, Varon J, Sternbach GL and Baskett P. Resuscitation great. Kouwenhoven, Jude and Knickerbocker: The introduction of defibrillation and external chest compressions into modern resuscitation. Resuscitation. 2005;64:139-43.

11. Hazinski MF, Nadkarni VM, Hickey RW, O'Connor R, Becker LB and Zaritsky A. Major changes in the 2005 AHA Guidelines for CPR and ECC: reaching the tipping point for change. Circulation. 2005;112:IV206-11.

12. Perkins GD, Handley AJ, Koster RW, et al. European Resuscitation Council Guidelines for Resuscitation 2015: Section 2. Adult basic life support and automated external defibrillation. Resuscitation. 2015;95:81-99.

13. Handley AJ, Koster R, Monsieurs K, et al. European Resuscitation Council guidelines for resuscitation 2005. Section 2. Adult basic life support and use of automated external defibrillators. Resuscitation. 2005;67 Suppl 1:S7-23.

14. Deakin CD, Nolan JP, Soar J, et al. European Resuscitation Council Guidelines for Resuscitation 2010 Section 4. Adult advanced life support. Resuscitation. 2010;81:1305-52.

15. Nolan JP, Soar J, Zideman DA, et al. European Resuscitation Council Guidelines for Resuscitation 2010 Section 1. Executive summary. Resuscitation. 2010;81:1219-76.

16. Valenzuela TD, Roe DJ, Nichol G, Clark LL, Spaite DW and Hardman RG. Outcomes of rapid defibrillation by security officers after cardiac arrest in casinos. N Engl J Med. 2000;343:1206-9.

17. Caffrey SL, Willoughby PJ, Pepe PE and Becker LB. Public use of automated external defibrillators. N Engl J Med. 2002;347:1242-7. 
18. Ornato JP, McBurnie MA, Nichol G, et al. The Public Access Defibrillation (PAD) trial: study design and rationale. Resuscitation. 2003;56:135-47.

19. van Alem AP, Vrenken RH, de Vos R, Tijssen JG and Koster RW. Use of automated external defibrillator by first responders in out of hospital cardiac arrest: prospective controlled trial. BMJ. 2003;327:1312.

20. Husain S and Eisenberg M. Police AED programs: a systematic review and meta-analysis. Resuscitation. 2013;84:1184-91.

21. Ringh M, Fredman D, Nordberg P, Stark T and Hollenberg J. Mobile phone technology identifies and recruits trained citizens to perform CPR on out-of-hospital cardiac arrest victims prior to ambulance arrival. Resuscitation. 2011;82:1514-8.

22. Ringh $M$, Rosenqvist $M$, Hollenberg J, et al. Mobile-phone dispatch of laypersons for CPR in out-ofhospital cardiac arrest. N Engl J Med. 2015;372:2316-25.

23. Brooks SC, Simmons G, Worthington H, Bobrow BJ and Morrison LJ. The PulsePoint Respond mobile device application to crowdsource basic life support for patients with out-of-hospital cardiac arrest: Challenges for optimal implementation. Resuscitation. 2016;98:20-6.

24. Smith $\mathrm{CM}$, Wilson $\mathrm{MH}$, Ghorbangholi $\mathrm{A}$, et al. The use of trained volunteers in the response to outof-hospital cardiac arrest - the GoodSAM experience. Resuscitation. 2017;121:123-126.

25. Hasselqvist-Ax I, Nordberg P, Herlitz J, et al. Dispatch of Firefighters and Police Officers in Out-ofHospital Cardiac Arrest: A Nationwide Prospective Cohort Trial Using Propensity Score Analysis. J Am Heart Assoc. 2017;6. 


\section{Chapter 2}

\section{A text message alert system for trained volunteers improves out-of-hospital cardiac arrest survival}

Ruud W.M. Pijls, Patty J. Nelemans, Braim M. Rahel, Anton P.M. Gorgels 


\section{Abstract}

\section{Aims}

The survival rate of sudden out-of-hospital cardiac arrests (OHCAs) increases by early notification of Emergency Medical Systems (EMS) and early application of basic life support (BLS) techniques and defibrillation. A Text Message (TM) alert system for trained volunteers in the community was implemented in the Netherlands to reduce response times. The aim of this study was to assess if this system improves survival after OHCA.

\section{Methods and Results}

From April 2012 to April 2014 data on all 1546 emergency calls for OHCA in the Dutch province of Limburg were collected according to the Utstein template. On site resuscitation attempts for presumed cardiac arrest were made in 833 cases, of which the TM-alert system was activated in 422 cases. Two cardiopulmonary resuscitation (CPR) scenarios were compared: 1. TM-alert system was activated but no responders attended $(n=131)$, and 2. TM-alert system was activated with attendance of $\geq 1$ responder(s) ( $n=291)$. Survival to hospital discharge was $16.0 \%$ in scenario 1 and $27.1 \%$ in scenario 2 corresponding with $\mathrm{OR}=1.95$ (95\% Cl 1.15-3.33; $P=.014)$. After adjustment for potential confounders the odds ratio increased (OR=2.82; 95\% $\mathrm{Cl} 1.52-5.24 ; P=.001)$. Of the 100 survivors, $92 \%$ were discharged from the hospital to their home with no or limited neurological sequelae.

\section{Conclusion}

The TM-alert system is effective in increasing survival to hospital discharge in OHCA victims and the degree of disability or dependence after survival is low. 


\section{Introduction}

Sudden out-of-hospital circulatory arrest (OHCA) is an important public health problem ${ }^{1,2}$, largely caused by cardiac disease. ${ }^{3}$ Survival rates are $\operatorname{low}^{4-6}(<10 \%)$ and increase by early notification of Emergency Medical Systems (EMS) and early application of basic life support and defibrillation. ${ }^{6}$

In $50-70 \%$ of victims, their cardiac arrest occurs at home ${ }^{1}$ and improving outcomes after $\mathrm{OHCA}$ requires new strategies. To counteract delayed ambulance arrival times, first responder systems were implemented in several countries. ${ }^{7,8}$ In a number of regions in the Netherlands, a novel system was introduced where citizen volunteers trained in resuscitation and the use of an Automated External Defibrillator (AED) are notified by the EMS dispatch centre, using a text message (TM) notification, to go to an OHCA victim in their zip code based vicinity. The aim of this study, executed in the Dutch province of Limburg, has been to assess the ability of this TM-alert system to improve outcomes after OHCA.

\section{Methods}

\section{Setting}

A prospective registry included all OHCAs in the Dutch province of Limburg for which EMS were called between April 2012 and April 2014. Variables were gathered according to the Utstein recommendations and definitions ${ }^{9-11}$ for assessing the contribution to survival of the TM-alert system. The study region consists of 1.12 million inhabitants living in an area of approximately $2153 \mathrm{~km}^{2}\left(831 \mathrm{mi}^{2}\right)$. Approval for the study was obtained from the medical ethics committee of the Maastricht University Medical Centre (project number 114029).

\section{Resuscitation volunteer network in the study region}

If EMS are called for (suspected) OHCA, the professional procedure throughout the Netherlands consists of dispatching two ambulances to the scene. Each vehicle is manned by one paramedic and a driver with CPR skills and equipped for providing advanced life support. First responders (policemen) are notified only if they are already in close range of the circulatory arrest case. To reduce the delay in response time to start BLS, a network of BLS/AED trained volunteers was developed. This network consists of TM-volunteers and AEDS placed in residential areas. TM-volunteers are notified by the dispatch centre, using the zip code derived location of the victim and the TM-volunteers. In a suspected OHCA, the dispatch centralist activates the system simultaneously with the two ambulances. Zip code identified TM-volunteers within a radius of $1 \mathrm{~km}(0.62 \mathrm{mi})$ of the victim receive a $\mathrm{TM}$, directing them to the scene to either start BLS (1/3 of notifications) or to get a nearest network AED first $(2 / 3)$. During the study period the network comprised 17 of the 24 Dutch dispatch centres 
and 61,000 TM-volunteers, including two dispatch centres and $>9000$ volunteers $(8.3 / 1000$ inhabitants) in Limburg.

Notification of TM-volunteers does not result in a predictable response, because this depends on the number of TM-volunteers in the specific zip code area and their availability. The dispatcher is not aware of actual attendance of volunteers.

To analyse the effect of attending TM-volunteers, two different resuscitation scenarios were compared. In scenario 1 the TM-alert system was activated but no TM-volunteers responded to the notification. This unwanted situation will improve with further implementation of the system, but for the purpose of our study these cases were considered as the reference group because survival of the OHCA victims depended on standard care. In scenario 2 the TM-alert system was activated and at least one TM-volunteer responded to the notification.

The primary outcome measure was the proportion of OHCA victims who survived to hospital discharge. Secondary outcome measures were proportion with return of spontaneous circulation (ROSC) at departure from site of the OHCA and at hospital arrival, proportion with discharge to rehabilitation centre and nursing/caring home and Modified Rankin score ${ }^{12}$ (mRS) at discharge.

\section{Data collection}

Data were retrieved from the following sources: 1 . the dispatch centres from Limburg North and South, 2. their respective emergency medical services, 3. notified volunteers, 4. TM-alert database $\left(\right.$ HartslagNu $\left.^{\circledR}\right)$, 5. the six hospitals in Limburg, and 6. AED providers.

On a daily basis, all emergency calls in the dispatch centre system were screened for suspected OHCAs. Data collected consisted of notification time, ambulance departure time and arrival time at the location, departure time to and arrival time at the hospital, patient's condition and treatment. Information was also obtained from the paramedics notes on the resuscitation scenario. The TM-alert system organisation provided information about the activation of the TM-alert system, such as the time the TM was sent, the number of notified TM-volunteers and AEDs, and type of notification (start BLS or first get an AED).

All notified TM-volunteers received a questionnaire gathering information about their attendance and if applicable about details of the CPR scenario. Information included the presence of a witness and the start of CPR by the witness or by a bystander. Importantly, a witness was defined as the one who saw, heard or monitored the arrest whereas the term bystander was reserved for those who did not witness the event but arrived the scene as well (e.g. a neighbour alarmed by the witness). Also recorded was if and how many TM-volunteers reached the scene. From the six hospitals receiving the victims, information was gathered about the post resuscitation treatment, outcome and discharge date, and if applicable, the medical history before OHCA. To acquire information about the quality of survival, discharge to the patients home, to a rehabilitation centre or to a nursing/caring facility was used as an indicator for cerebral outcome. Additionally, in one hospital (Maastricht) the Modified Rankin Scale ${ }^{12}$ was used to determine the degree of disability at hospital discharge. The 
scores were derived from chart review. AED recordings were retrieved from the TM-alert system organisation or from private AED providers.

\section{Statistical analysis}

Patients with OHCA were categorised into two groups according to the corresponding CPR scenario. The distribution of age, gender, witnessed OHCA and other potential determinants of survival at hospital discharge were compared between the two CPR scenarios. Categorical variables were described as absolute numbers and percentages, and continuous variables as means with standard deviation or medians with interquartile range. The Chi square test was used to test for statistically significant differences between proportions. The $t$-test for independent samples or the Mann Whitney U-test was used for continuous variables.

To assess whether mobilisation of TM-volunteers improved probability of survival, odds ratios as a measure of relative risk with $95 \%$ confidence interval $(95 \% \mathrm{Cl})$ were calculated using scenario 1 as reference category. Multivariable logistic regression analyses were performed to assess the contribution to survival of scenario 2 with adjustment for between group differences in potential determinants of probability of survival. A $P$-value of $\leq 0.05$ was considered as statistically significant. The statistical software package of SPSS (SPSS for Windows, version 22.0, SPSS Inc, Chicago, IL) was used to analyse the data.

\section{Results}

Fig. 1 depicts the flowchart of the study population. Out of a total of 1546 OHCA EMS notifications during the 24 months study period, 1040 resuscitation attempts were recorded. The group of 506 cases without a resuscitation attempt consisted of 461 cases being pronounced dead on arrival of the EMS and 45 with a "do not resuscitate" statement. Arrests within the ambulance were excluded and occurred in 31 instances. Another five cases were excluded, because they were, after sufficient recovery, discharged to a hospital outside the Netherlands and no information on outcome could be acquired. Because the purpose of this study was to evaluate the effect of the TM-system on arrests with a cardiac origin, 171 arrests with a non-cardiac origin were excluded. In 411 (49.3\%) cases the dispatch centre decided not to activate the system mostly because the ambulance was already nearby or present at the scene, or the OHCA occurred in a (closed) public place with an on-site AED (such as shopping malls, sport venues etc.). These cases were excluded from the analysis. Hence, the total study population consisted of 422 (presumed) cardiac arrests in which the TM-alert system was activated. In 291 cases (69\%) $\geq 1$ TM-volunteers attended (scenario 2), and in 131 cases (31\%) no responder attended (scenario 1, reference group). 


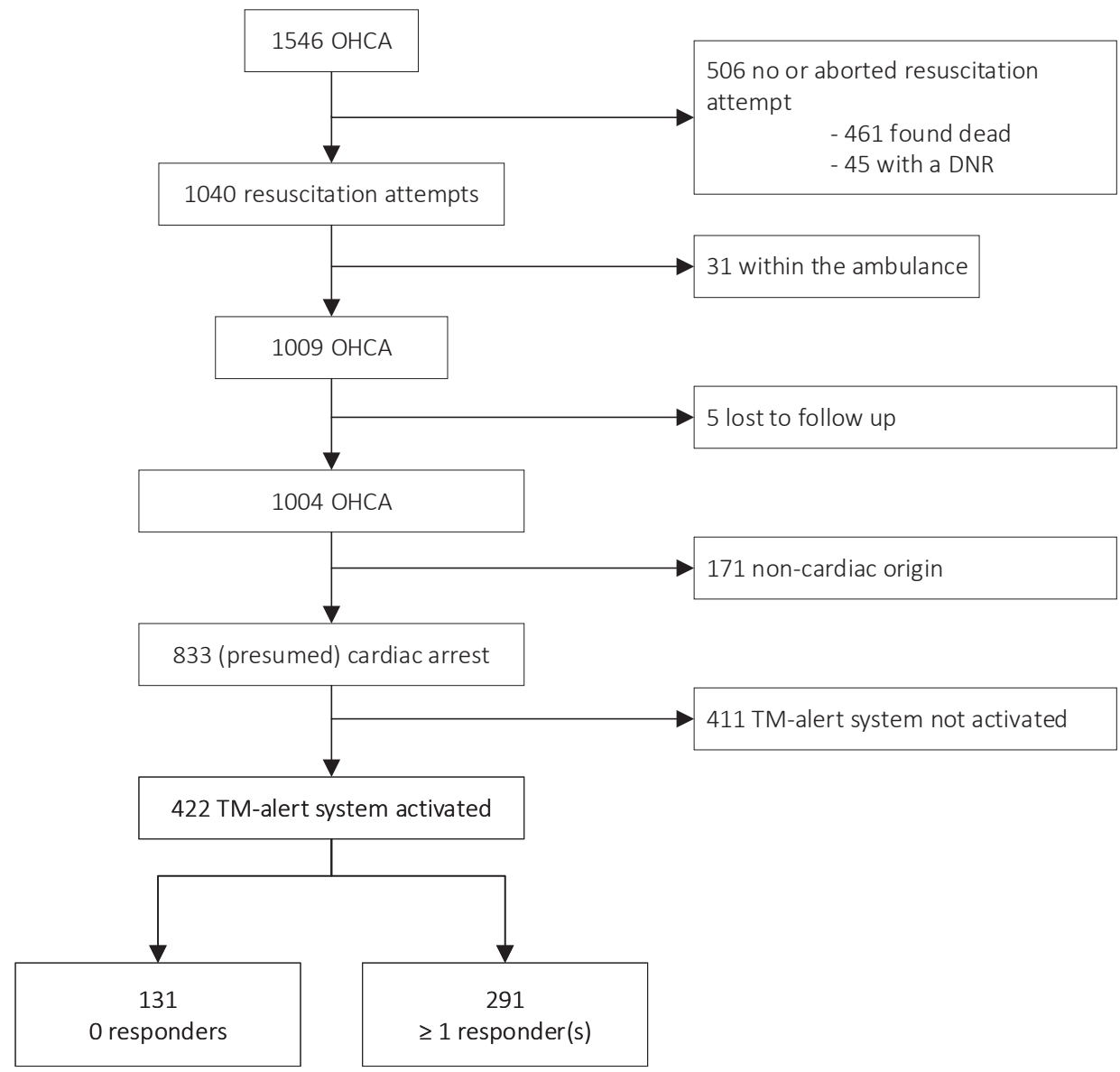

Fig. 1. Flowchart of patient inclusion. OHCA indicates out-of-hospital circulatory arrest; DNR, do not resuscitate policy; system activated 0 TM-responders, scenario 1 ; system activated $\geq 1$ TM-responder, scenario 2.

\section{Baseline characteristics}

The mean age of these 422 OHCA victims was 68.1 years and $71.6 \%$ were male. Table 1 shows the distribution of the baseline variables among the two scenarios. Study groups were comparable regarding most variables, but significant differences were observed with respect to initial rhythm and the person who started BLS. In scenario 2, BLS was less often started by a witness (35.8\% vs $41.5 \%$ ) and more often by other parties. In scenario 2, a TM-volunteer started BLS in $24.7 \%$. Patients in scenario 2 were more likely to have a shockable initial rhythm compared to the patients in scenario 1 (59.9\% vs. 46.5\%; $P=.011$ ). Although differences were not statistically significant, patients in scenario 2 were slightly older than patients in scenario 1 and the ambulance arrived more often after $8 \mathrm{~min}$ (50.9\% vs 43.3\%). The lack of difference in departure times between the first and second ambulance suggests equal accurateness in both scenarios in identifying OHCAs by the dispatch centralist. 
Table 1 Distribution of baseline variables among the two CPR scenarios.

\begin{tabular}{|c|c|c|c|c|c|}
\hline Demographic and clinical variable & \multicolumn{2}{|c|}{$\begin{array}{l}\text { Scenario } 1 \\
N=131\end{array}$} & \multicolumn{2}{|c|}{$\begin{array}{l}\text { Scenario } 2 \\
N=291\end{array}$} & $P$-value \\
\hline Age, mean (SD), years, $n=422$ & 67.0 & $( \pm 11.9)$ & 68.7 & $( \pm 14.3)$ & .241 \\
\hline $\begin{array}{l}\text { Gender, No. (\%), } n=422 \\
\quad \text { Male } \\
\text { Female }\end{array}$ & $\begin{array}{l}97 \\
34\end{array}$ & $\begin{array}{l}(74.0) \\
(26.0)\end{array}$ & $\begin{array}{l}205 \\
86\end{array}$ & $\begin{array}{l}(70.4) \\
(29.6)\end{array}$ & .448 \\
\hline $\begin{array}{l}\text { Cardiac history, No. (\%), } n=403 \\
\text { Yes } \\
\text { No }\end{array}$ & $\begin{array}{l}51 \\
72\end{array}$ & $\begin{array}{l}(41.5) \\
(58.5)\end{array}$ & $\begin{array}{l}128 \\
152\end{array}$ & $\begin{array}{l}(45.7) \\
(54.3)\end{array}$ & .429 \\
\hline
\end{tabular}

\section{Resuscitation variables}

Location of the arrest, No. (\%), $n=422$

Home

Public location

105

$(80.2) \quad 243$

$\begin{array}{lll}26 & (19.8) \quad 48\end{array}$

(83.5)

Witnessed, No. (\%), $n=422$

Yes

$99 \quad(75.6) \quad 218$

(16.5)

No

(24.4) $\quad 73$

(74.9)

(25.1)

BLS started by, No. (\%), $n=418$

Witness

$54 \quad(41.5) \quad 103$

(35.8)

Bystanders

(23.8) $\quad 74$

EMS

(23.8) 27

TM-responders

(0.0) 71

First responders

(10.8) $\quad 13$

.402

.885

$<.001$

14

(4.5)

Initial rhythm recorded, No. (\%), $n=416$

Asystole/ PEA/ EMD

VT/ VF

Other $^{a}$

$\begin{array}{lll}68 & (52.7) & 111 \\ 60 & (46.5) & 172 \\ 1 & (0.8) & 4\end{array}$

.027

Shock delivered, No. (\%), $n=422$

Yes

$\begin{array}{lll}76 & (58.0) \quad 189\end{array}$

No

55

(42.0) $\quad 102$

.173

\section{Ambulance times}

Time until arrival of first ambulance, No. (\%), $n=412$

$\begin{array}{lllll}\leq 6 \text { minutes } & 36 & (28.3) & 76 & (26.7) \\ 7-8 \text { minutes } & 36 & (28.3) & 64 & (22.5) \\ 9-10 \text { minutes } & 24 & (18.9) & 64 & (22.5) \\ \geq 11 \text { minutes } & 31 & (24.4) & 81 & (28.4)\end{array}$

Difference between departure time of the first and second ambulance, $n=372$

Median (minutes)

$\begin{array}{lll}1 & (0.5-3) & 1\end{array}$

$(0-3)$

.624

Scenario 1 indicates system activated 0 TM-responders; scenario 2, system activated $\geq 1$ TM-responder; BLS, basic life support; EMS, emergency medical system; TM, text message; PEA, pulseless electrical activity; EMD, electromechanical dissociation; VT, ventricular tachycardia; VF, ventricular fibrillation.

a Other: Total AV-block, bradycardia in inferior wall acute coronary syndrome, sinus rhythm in collapse due to severe aortic stenosis, strong vagal reaction in atrial fibrillation, sinus rhythm after unidentified non-perfusing rhythm. 


\section{Contribution of TM-responders to survival}

Survival to hospital discharge of $27.1 \%$ (79/291) in scenario 2 was significantly higher compared to $16.0 \%(21 / 131 ; P=.013)$ in scenario 1 . In total, 100 of the 422 victims $(23.7 \%)$ were discharged alive from the hospital. Percentages with specific clinical outcomes among the scenarios are depicted in Table 2. The percentages of victims with ROSC at departure from the site of the event and at hospital arrival was higher in scenario 2 (41.4\% respectively $41.7 \%)$ than in scenario 1 (30.5\% respectively 32.3\%), although not reaching statistical significance ( $P=.063$ and $P=.098$, respectively). Moreover, 79 (47.9\%) in scenario 2 compared to $20(30.8 \%)$ in scenario 1 arrived at the hospital with ROSC or "CPR continued"

Table 2 Percentage of patients with specific clinical outcome among the two CPR scenarios.

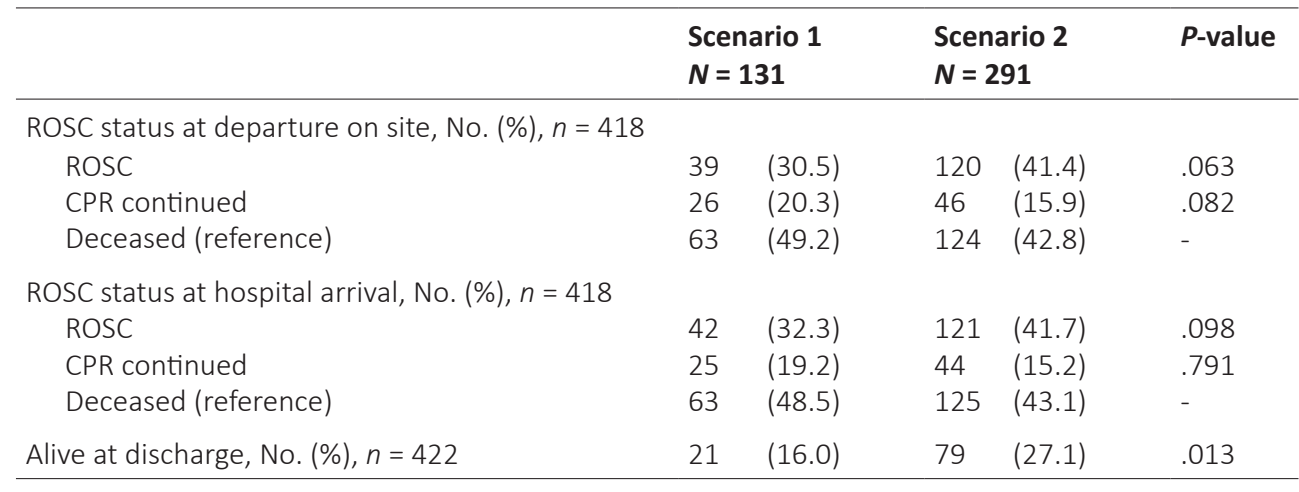

Scenario 1 indicates system activated 0 TM-responders; scenario 2, system activated $\geq 1$ TM-responder; ROSC, return of spontaneous circulation; CPR, cardiopulmonary resuscitation.

Table 3 shows the results from univariable and multivariable logistic regression analyses with survival at discharge as dependent variable and comparing scenarios 1 and 2 in terms of odds ratios. The probability of survival decreases with increasing age, but male sex, presence of a witness, start of BLS by a witness and arrival of the first ambulance within 6 min are associated with significant increase of survival probability. Patients in scenario 2 had a higher probability of survival at hospital discharge than patients in scenario 1 with an odds ratio 1.95 (95\% Cl 1.15-3.33; $P=.014$ ). After correction for potential confounders (age, sex, location of the arrest, witnessed arrest, BLS started by witness or other parties, time until arrival of the first ambulance), the odds ratio increased to 2.82 (95\% Cl 1.52-5.24; $P=.001$ ) compared to scenario 1. 
Table 3 Unadjusted and adjusted odds ratios for survival at discharge from hospital derived from univariable and multivariable logistic regression analysis.

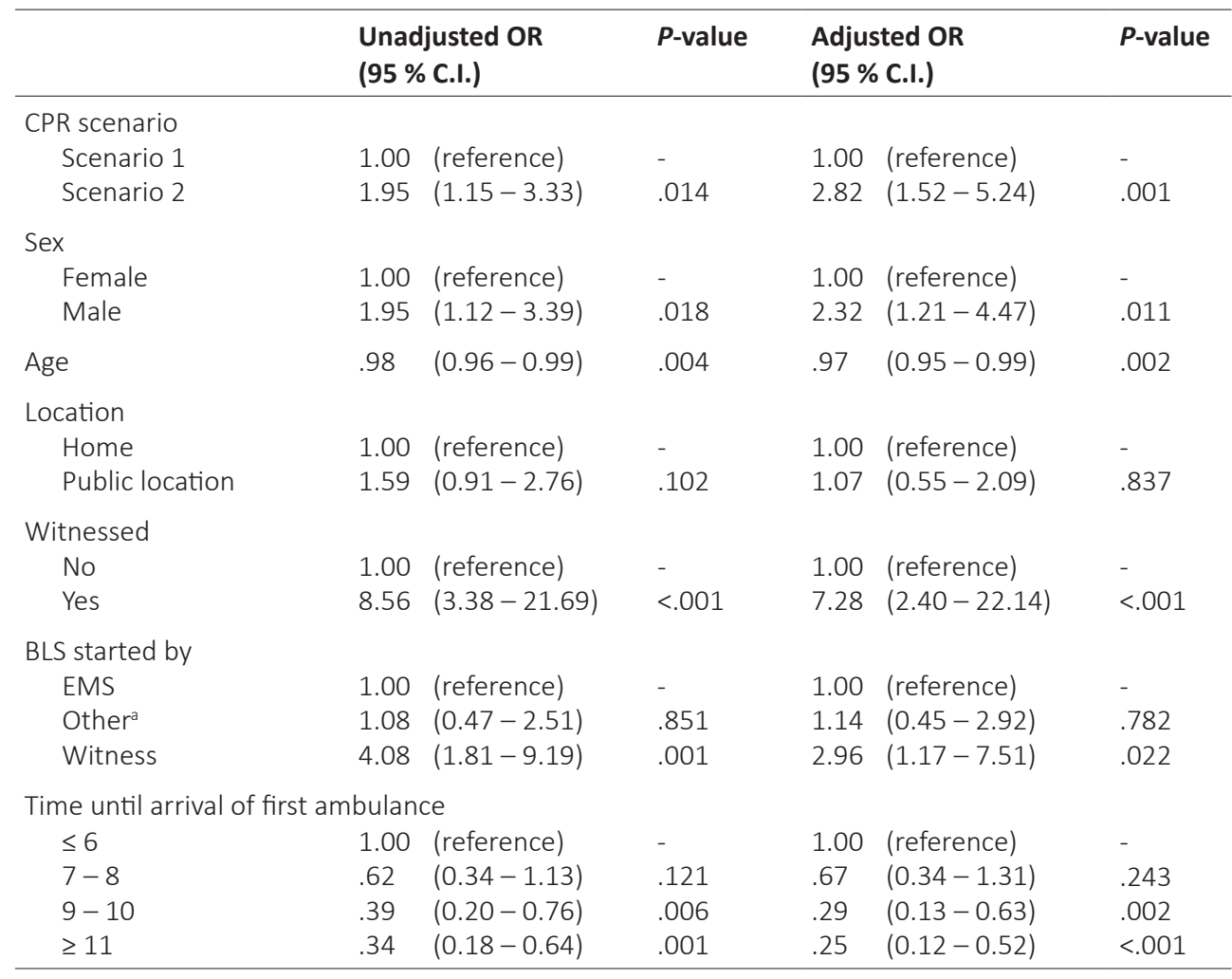

Scenario 1 indicates system activated 0 TM-responders; scenario 2, system activated $\geq 1$ TM-responder; OR, odds ratio; $\mathrm{Cl}$, 95\% confidence interval; CPR, cardiopulmonary resuscitation; BLS, basic life support; EMS, emergency medical services; VT, ventricular tachycardia; VF, ventricular fibrillation.

a Other: bystander, first responder.

\section{Quality of life of survivors}

Of the 100 patients who were discharged alive from the hospitals, 92 (92.0\%) were discharged home, five $(5.0 \%)$ were referred to a rehabilitation centre, and three $(3.0 \%)$ to a nursing home. Scores on the Modified Rankin Scale were available for a subgroup of 34 survivors, who were discharged from the Maastricht University Medical Centre. Within this group, 28 patients $(82.4 \%)$ had no significant to slight disability with a score of 0 to 2 , whereas scores $3-5$ were observed in six patients $(17.6 \%)$. 


\section{Discussion}

\section{Main findings}

This is a population based survey, performed in a well-defined area in the Netherlands, including all consecutive resuscitations of OHCA cases during a 2 year period, studying the contribution of a novel citizen responder system (Table 1 ). Results showed improved outcomes in survival to hospital discharge when 1 or more TM-volunteers responded with $27.1 \%$ survival $(79 / 291)$ compared to $16.0 \%(21 / 131)$ in case no volunteer responded $(P=.001)$.

After correction for differences in the distribution of other determinants of survival, the adjusted relative risk estimate of survival at hospital discharge in scenario 2 was $2.82(95 \% \mathrm{Cl}$ 1.52-5.24; $P=.001$ ) compared to scenario 1 (Table 3). Survivors had a low degree of disability or dependence, as suggested by the low referral rate to rehabilitation or nursing centres (8\%) and accordingly low scores in the majority of survivors with an available Modified Rankin score.

\section{Study population and the TM-alert system}

Our study group consists of consecutive cases from the general population. The TM-alert system was activated in $50.7 \%$ of resuscitations for OHCA with a (presumed) cardiac cause. In about one third of these cases, no volunteer responded, either due to the absence or nonavailability of volunteers in the zip code area of the victim. With further implementation of the system the number of citizen volunteers will increase, with expectedly higher attendance rates. Where we studied the system comprising 61,000 volunteers, at the moment of this writing the TM-alert system studied contains already more than 91,000 rescuers. The fact that during the study period no volunteer attended in a substantial number of cases provided us with the opportunity to handle these cases (scenario 1) as a reference group, because they were derived from the same population as the group where volunteers attended (scenario 2) but had to depend on standard care.

Our findings suggest that the lay rescuer system substantially contributed to different links in the chain of survival: 1 . In $24.7 \%$ of the 291 cases where TM-responders did arrive on the scene, they were the first to start BLS and in $26.8 \%$ they were the first to connect an AED. The higher survival rate in scenario 2 compared to scenario 1 suggests that the TM-alert system is successful in decreasing response time. 2 . The observation that the initially recorded rhythm was more often shockable in scenario 2 compared to scenario 1 ( $59.9 \%$ vs $46.5 \%, P=.015$ ), is probably also related to the shorter arrival times and adequate BLS. 3 . The probability to arrive at the hospital alive was higher in the study arm with $\geq 1$ responders $(47.9 \%$ vs $30.8 \%)$. Moreover this difference not only persisted but further increased as reflected by higher survival at hospital discharge, suggesting a better medical condition at hospital arrival. 


\section{Other factors contributing to survival}

Like in comparable studies regarding survival of OHCA, multivariable logistic regression analysis suggested that higher age was associated with worse survival whereas male sex, particularly witnessed OHCA, BLS started by a witness and a short arrival time of the first ambulance were associated with better survival (Table 3).

\section{Quality of survival}

The low degree of disability of survivors in our study population is in agreement with recent studies by Moulaert et al. in the same geographical area. Here it was found that almost $80 \%$ of the patients experience high quality of life $^{13}$ and that $70 \%$ of employed patients returned to work within 12 months after discharge. ${ }^{14}$

\section{Comparison with other community responder systems}

In different countries different strategies exist to involve citizen volunteers for improving survival of OHCA. ${ }^{15,16}$ To our knowledge, however, no data on their contribution to survival have been published thus far.

The Dutch TM-alert system was recently evaluated in two other regions, but this research was focused on the use of AEDs and no survival data were reported. ${ }^{17}$

\section{Limitations}

The design of the study was observational. More formal proof of the effect of the TMalert system would require a (randomised) controlled study design. Such an approach is impossible, given the already widespread implementation of the system. Exact information on neurological outcome was not available due to practical limitations. However $92 \%$ of the surviving patients were discharged home and assessment of scores on the Modified Rankin Scale in one hospital provided good functional outcomes, in agreement with results from previous research in the same region ${ }^{13,14}$ and elsewhere in the Netherlands. ${ }^{18,19}$

Five foreign patients were excluded, because they were, after sufficient recovery within the local hospital in Limburg, transferred to a hospital outside the Netherlands. They therefore likely survived, but their survival status could not be confirmed.

Although we tried to obtain accurate information from the notified TM-volunteers by use of a questionnaire, it was practically impossible, due to the rapidly changing nature of a resuscitation setting, to retrieve exact numbers of TM-responders and their arrival times at the location. Therefore, the reduction in response times could not be quantified. 


\section{Conclusion}

The TM-alert system has shown to be effective in increasing survival to hospital discharge in OHCA victims. About $90 \%$ of survivors went home after hospital discharge. Further improvement in survival will likely be achieved by a higher density and availability of citizen rescuers.

\section{Conflict of interest statement}

None declared.

\section{Funding}

This work was supported by the Province Limburg [SAS-202-01794] and the Mercurius Foundation [30957210N].

\section{Acknowledgments}

We are greatly indebted to the Province Limburg and the Mercurius Foundation for the financial support of this study; F.W. Lindemans, PhD and Prof. H.J.J. Wellens for their support and suggestions; the staff of the participating hospitals, other institutions and medical students for helping in collecting the data: Zuyderland hospital Sittard/Heerlen; dr. D. van Kraaij, dr. H. Kragten and the R\&D Cardiology; Laurentius hospital Roermond, dr. C. Werter and mrs. M. Janssen; Sint Jans Gasthuis Weert, dr. H. Klomps, and Viecuri Venlo; the emergency medical services of the GGD South-Limburg (mr. N. Otten) and AmbulanceZorg Limburg-North (mr. L. Triepels), Hartslagnu and Ocean (mr. Theo Schrijnemaekers); police department district Limburg South, AED solutions (mr. R. Henderikx), BHV-competent (mr. J. Hoofs), Vivon (mr. M. van Gorp ${ }^{\dagger}$ ). 


\section{References}

1. de Vreede-Swagemakers JJ, Gorgels AP, Dubois-Arbouw WI, et al. Out-of-hospital cardiac arrest in the 1990's: a population-based study in the Maastricht area on incidence, characteristics and survival. J Am Coll Cardiol. 1997;30:1500-5.

2. Berdowski J, Berg RA, Tijssen JG and Koster RW. Global incidences of out-of-hospital cardiac arrest and survival rates: Systematic review of 67 prospective studies. Resuscitation. 2010;81:1479-87.

3. Zipes DP and Wellens HJ. Sudden cardiac death. Circulation. 1998;98:2334-51.

4. Waalewijn RA, de Vos R and Koster RW. Out-of-hospital cardiac arrests in Amsterdam and its surrounding areas: results from the Amsterdam resuscitation study (ARREST) in 'Utstein' style. Resuscitation. 1998;38:157-67.

5. Sasson C, Rogers MA, Dahl J and Kellermann AL. Predictors of survival from out-of-hospital cardiac arrest: a systematic review and meta-analysis. Circ Cardiovasc Qual Outcomes. 2010;3:63-81.

6. Hasselqvist-Ax I, Riva G, Herlitz J, et al. Early cardiopulmonary resuscitation in out-of-hospital cardiac arrest. N Engl J Med. 2015;372:2307-15.

7. de Vries W, van Alem AP, de Vos R, van Oostrom J and Koster RW. Trained first-responders with an automated external defibrillator: how do they perform in real resuscitation attempts? Resuscitation. 2005;64:157-61.

8. Husain S and Eisenberg M. Police AED programs: a systematic review and meta-analysis. Resuscitation. 2013;84:1184-91.

9. Jacobs I, Nadkarni V, Bahr J, et al. Cardiac arrest and cardiopulmonary resuscitation outcome reports: update and simplification of the Utstein templates for resuscitation registries: a statement for healthcare professionals from a task force of the International Liaison Committee on Resuscitation (American Heart Association, European Resuscitation Council, Australian Resuscitation Council, New Zealand Resuscitation Council, Heart and Stroke Foundation of Canada, InterAmerican Heart Foundation, Resuscitation Councils of Southern Africa). Circulation. 2004;110:3385-97.

10. Peberdy MA, Cretikos M, Abella BS, et al. Recommended guidelines for monitoring, reporting, and conducting research on medical emergency team, outreach, and rapid response systems: an Utstein-style scientific statement: a scientific statement from the International Liaison Committee on Resuscitation (American Heart Association, Australian Resuscitation Council, European Resuscitation Council, Heart and Stroke Foundation of Canada, InterAmerican Heart Foundation, Resuscitation Council of Southern Africa, and the New Zealand Resuscitation Council); the American Heart Association Emergency Cardiovascular Care Committee; the Council on Cardiopulmonary, Perioperative, and Critical Care; and the Interdisciplinary Working Group on Quality of Care and Outcomes Research. Circulation. 2007;116:2481-500. 
11. Perkins GD, Jacobs IG, Nadkarni VM, et al. Cardiac arrest and cardiopulmonary resuscitation outcome reports: update of the Utstein Resuscitation Registry Templates for Out-of-Hospital Cardiac Arrest: a statement for healthcare professionals from a task force of the International Liaison Committee on Resuscitation (American Heart Association, European Resuscitation Council, Australian and New Zealand Council on Resuscitation, Heart and Stroke Foundation of Canada, InterAmerican Heart Foundation, Resuscitation Council of Southern Africa, Resuscitation Council of Asia); and the American Heart Association Emergency Cardiovascular Care Committee and the Council on Cardiopulmonary, Critical Care, Perioperative and Resuscitation. Circulation. 2015;132:1286-300.

12. van Swieten JC, Koudstaal PJ, Visser MC, Schouten HJ and van Gijn J. Interobserver agreement for the assessment of handicap in stroke patients. Stroke. 1988;19:604-7.

13. Wachelder EM, Moulaert VR, van Heugten C, Verbunt JA, Bekkers SC and Wade DT. Life after survival: long-term daily functioning and quality of life after an out-of-hospital cardiac arrest. Resuscitation. 2009;80:517-22.

14. Moulaert VR, van Heugten CM, Winkens B, et al. Early neurologically-focused follow-up after cardiac arrest improves quality of life at one year: A randomised controlled trial. Int J Cardiol. 2015;193:8-16.

15. Ringh M, Fredman D, Nordberg P, Stark T and Hollenberg J. Mobile phone technology identifies and recruits trained citizens to perform CPR on out-of-hospital cardiac arrest victims prior to ambulance arrival. Resuscitation. 2011;82:1514-8.

16. Hansen CM, Lippert FK, Wissenberg M, et al. Temporal trends in coverage of historical cardiac arrests using a volunteer-based network of automated external defibrillators accessible to laypersons and emergency dispatch centers. Circulation. 2014;130:1859-67.

17. Zijlstra JA, Stieglis R, Riedijk F, Smeekes M, van der Worp WE and Koster RW. Local lay rescuers with AEDs, alerted by text messages, contribute to early defibrillation in a Dutch out-of-hospital cardiac arrest dispatch system. Resuscitation. 2014;85:1444-9.

18. Blom MT, Beesems SG, Homma PC, et al. Improved survival after out-of-hospital cardiac arrest and use of automated external defibrillators. Circulation. 2014;130:1868-75.

19. van Alem AP, Waalewijn RA, Koster RW and de Vos R. Assessment of quality of life and cognitive function after out-of-hospital cardiac arrest with successful resuscitation. Am J Cardiol. 2004;93:131-5. 


\section{Chapter 3}

Factors modifying performance of a novel citizen text message alert system in improving survival of out-of-hospital cardiac arrest

Ruud W.M. Pijls, Patty J. Nelemans, Braim M. Rahel, Anton P.M. Gorgels 


\section{Abstract}

\section{Aims}

Recently we found that the text message alert system increases survival of sudden out-ofhospital cardiac arrest. The aim of the present study is to explore the contribution of the system to survival specifically in resuscitation settings with prolonged delay of start of resuscitation.

\section{Methods and results}

Data were used from consecutive patients resuscitated for out-of-hospital cardiac arrest during a two-year period in the Dutch province Limburg. Survival of 291 cases with out-ofhospital cardiac arrest where one or more volunteers attended (Scenario 2) was compared with survival of 131 cases with out-of-hospital cardiac arrest where no volunteers attended and only standard care was given (Scenario 1). Multivariable logistic regression models including terms for interaction between scenario and the covariate coding for resuscitation setting were used to test for effect modification. The highest impact on survival of the alert system was observed in cases of (a) witnessed arrests (odds ratio=2.25; 95\% confidence interval: $1.27-4.00 ; P=.005$ ); (b) arrests that occurred in the home (odds ratio $=2.28 ; 95 \%$ confidence interval: $1.21-4.28 ; P=.011$ ); (c) arrival of the ambulance with a delay of $7-10 \mathrm{~min}$ (odds ratio=2.63; 95\% confidence interval: 1.09-6.35; $P=.032$ ); and (d) arrests at evening/ night (odds ratio=3.07; 95\% confidence interval: $1.34-7.03 ; P=.008$ ). Due to the low sample size, $P$-values from tests for interaction were non-significant.

\section{Conclusion}

The contribution of the alert system to survival is most substantial in cases of witnessed arrest, in the home situation, at slightly delayed arrival of the first ambulance and during the evening/night. 


\section{Introduction}

To improve outcomes of sudden out-of-hospital cardiac arrest (OHCA), a novel citizen alert system was implemented in several regions in the Netherlands. Besides activating two ambulances, the dispatch centre also notifies citizen volunteers by text message (TM). Within their zip code vicinity, those volunteers are requested to go to the presumed arrest and either start basic life support (BLS) or first get an automated external defibrillator (AED).

Recently, we performed a study in the Dutch province Limburg to assess the value of this system. ${ }^{1}$ If the system was activated but no volunteer responded (Scenario 1 ) then only standard care was given and therefore this scenario was used as the reference group. It was found that survival to hospital discharge substantially increased from $16.0 \%$ to $27.1 \%$, when at least one volunteer responded (Scenario 2 ) to the notification. ${ }^{1}$

In the study at hand we aimed to explore the contribution of the alert system to survival specifically in situations with prolonged delay of start of resuscitation. The rationale behind the system is that responders can contribute to survival because they help to reduce the period between onset of the arrest and start of cardiopulmonary resuscitation (CPR) sufficiently soon after the collapse. Therefore, it was hypothesised that the system is most effective in situations where there may be a delay in response time, such as in the home or at night, and longer ambulance arrival times. Furthermore, a reduction of response time was expected to be especially effective in witnessed victims, because in unwitnessed victims help and support may often come too late anyway.

\section{Methods}

\section{Setting}

The details of the study design and system have been published previously. ${ }^{1}$ From April 2012April 2014, a prospective registry included all OHCAs in the Dutch province of Limburg. The study region Limburg has an area of approximately $2153 \mathrm{~km}^{2}\left(831 \mathrm{mi}^{2}\right)$ and consists of 1.12 million inhabitants. Approval for the study was obtained from the medical ethics committee of the Maastricht University Medical Centre (project number 114029).

\section{Resuscitation volunteer network in the study region}

Throughout the Netherlands, two ambulances are dispatched in the case of an (suspected) OHCA, each ambulance including one paramedic and a driver with CPR skills. A network of BLS/AED certified volunteers was implemented throughout Limburg and other regions in the Netherlands in order to reduce the delay in response time to start CPR. Furthermore, registered network AEDs were placed specifically in residential areas. Using the zip code derived location of the arrest location and volunteers, the dispatch centre notifies volunteers, close to the OHCA, simultaneously with two ambulances. In a 1:2 fashion, zip code identified 
volunteers within a radius of $1 \mathrm{~km}(0.62 \mathrm{mi})$ of the OHCA are notified to either start BLS or to get an AED first by the nearest network. During the study period, the alert system was active in 17 of the 24 Dutch dispatch centres and included 61,000 registered volunteers. The system was implemented in both dispatch centres in Limburg with more than 9000 volunteers (8.3/1000). The response rate of volunteers is not predictable and depends on the number of volunteers in the specific zip code area and their actual availability. A maximum of 30 volunteers are notified to make sure a sufficient but not excessive number of volunteers responds to the notification.

\section{Data collection}

Data were used from a registry of all consecutive OHCAs which occurred during a twoyear period (April 2012-April 2014) in the Dutch province of Limburg. Data were collected according to the Utstein template. ${ }^{2-4}$ On a daily basis, all emergency calls were screened for suspected OHCAs. The data consisted of notification time, ambulance departure time and arrival time at the location, departure time to and arrival time at the hospital, patient's condition and treatment. Information was also obtained from the paramedic notes about the resuscitation scenario (e.g. whether the OHCA was witnessed or not, who started CPR and the sequence of laymen and professionals that attended the OHCA). The alert system organisation (Hartslagnu) provided information about the activation of the system, such as the time the TM was sent, the number of notified volunteers and AEDs, and type of notification (start BLS or first get an AED). All notified volunteers received a questionnaire to obtain information about their attendance and, if applicable, about details of the scenario. Information included the presence of a witness and the start of CPR by the witness or by a bystander. Importantly, a witness was defined as the one who saw, heard or monitored the OHCA. A bystander was defined as the one who did not witness the event but was at the scene as well (e.g. a neighbour called by the witness). From the six hospitals in the province of Limburg information was gathered about post-resuscitation treatment, clinical outcome and discharge date and, if available, the medical history before OHCA.

In this study, survival was compared between two resuscitation scenarios. In Scenario 1, the system was activated but no volunteer attended at the scene. In this situation, survival depended on standard care available from the two ambulances directed to the OHCA. In Scenario 2 , the system was activated and volunteers indeed responded. The primary outcome measure was the proportion of patients surviving until discharge from hospital.

\section{Statistical analysis}

OHCA cases were categorised into subgroups according to whether the OHCA was witnessed, the location of the arrest, the time until arrival of the first ambulance and the time of day. Proportions of patients surviving until hospital discharge and relative risk estimates of survival with 95\% confidence intervals (Cls), using Scenario 1 as the reference category, were calculated within subgroups (strata) which are referred to as stratum-specific odds ratios 
(ORs). Multivariable logistic regression analyses including scenario, the covariate coding for resuscitation setting and an interaction term for both variables were used to test for effect modification. Exponentiation of the regression coefficient corresponding with the interaction term gives the interaction OR. The interaction OR indicates whether the gain in survival due to the volunteer system differs between resuscitation settings (witnessed or not, location, arrival time of ambulance and time of day). An interaction $O R=1$ indicates equal survival benefit across strata. An interaction $\mathrm{OR}=2$ indicates doubling of survival benefit compared to the reference category and for example an interaction $\mathrm{OR}=0.50$ indicates halving of survival benefit compared to the reference category. Values of $P \leqslant 0.05$ were considered statistically significant. For the analyses the software package of SPSS (SPSS for Windows, version 22.0, SPSS Inc., Chicago, Illinois, USA) was used.

\section{Results}

The study population has been described previously. ${ }^{1}$ During the 24 -month study period a total of 833 victims had (presumed) cardiac arrest. The system was activated in 422 (50.7\%) cases and not activated in 411 (49.3\%) cases. If the system was not activated, this was mostly because an ambulance was nearby or present at the scene, or because the OHCA occurred in a (closed) public place with an on-site AED (such as shopping malls). For this study, only data from system-activated cases were used where one or more volunteers responded in 291 cases (Scenario 2) and no volunteers responded in 131 cases (Scenario 1) (see Figure 1). Scenario 1 was used as the reference group. 


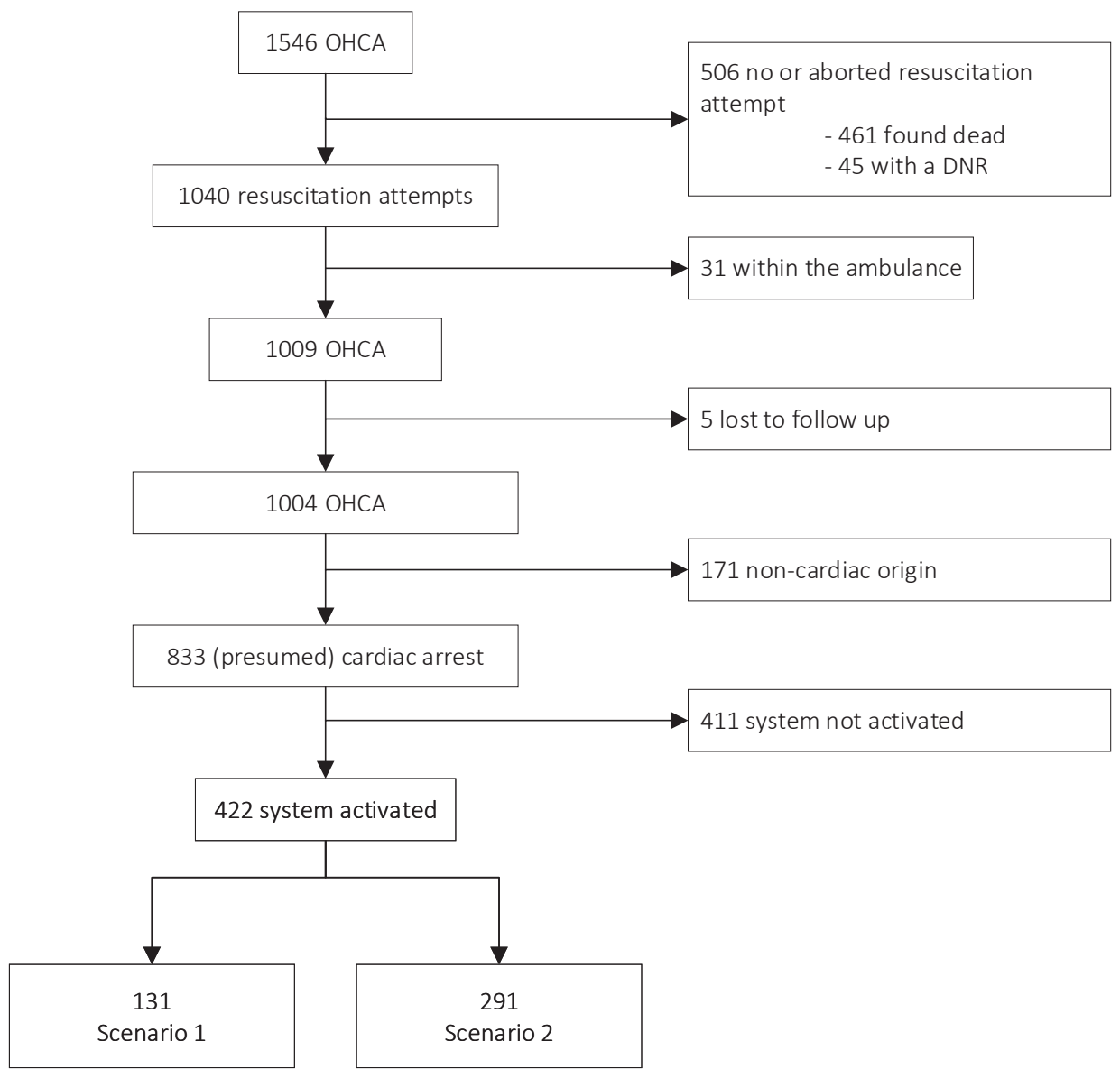

Fig. 1. Flowchart of patient inclusion. Scenario 1, system activated 0 responders; Scenario 2, system activated $\geq 1$ responder. DNR indicates do not resuscitate policy; OHCA, out-of-hospital cardiac arrest.

\section{Distribution of resuscitation settings}

Mean age was 68.1 years (standard deviation (SD) \pm 13.6 ) and $71.6 \%$ of OHCA victims were male. OHCA was witnessed in $75.1 \%$ of cases, and took place in the home situation in $82.5 \%$ of the cases. About $53.1 \%$ of the OHCAs occurred during the day vs $46.9 \%$ at evening or night (Table 1). In about $75 \%$ of cases the ambulance arrived after six minutes. The mean number of responding volunteers was 2.8 at daytime vs 2.9 at evening/night.

Scenario 1 indicates that the system was activated but no volunteers responded. Scenario 2 indicates that the system was activated and at least 1 volunteer responded. In case OHCA was witnessed, the majority of the OHCAs (92.7\%) occurred in at least one of the following settings: (a) in the home or (b) the arrival time of the first ambulance was between 6-11 min or (c) during the evening/night. 
Table 1. Percentages of survivors per scenario and total numbers (\%) within strata according to witness status, location, time until arrival of first ambulance and time of day.

\begin{tabular}{|c|c|c|c|}
\hline & Scenario 1 & Scenario 2 & Number (\%) \\
\hline \multicolumn{4}{|l|}{ Witnessed, No. (\%), $n=422$} \\
\hline No & $2 / 32 \quad(6.3)$ & $3 / 73 \quad(4.1)$ & 105 (24.9) \\
\hline Yes & 19/99 (19.2) & $76 / 218(34.9)$ & $317(75.1)$ \\
\hline \multicolumn{4}{|c|}{ Location of the arrest, No. (\%), $n=422$} \\
\hline Outside the home & $7 / 26 \quad(26.9)$ & $16 / 48(33.3)$ & 74 (17.5) \\
\hline Inside the home & $14 / 105(13.3)$ & $63 / 243(25.9)$ & $348(82.5)$ \\
\hline \multicolumn{4}{|c|}{ Time until arrival of first ambulance, No. (\%), $n=412$} \\
\hline$\leq 6$ minutes & $(25.0)$ & $30 / 76$ (39.5) & $112(27.2)$ \\
\hline $7-10$ minutes & $(11.7)$ & $33 / 128(25.8)$ & $188(45.6)$ \\
\hline$\geq 11$ minutes & $(12.9)$ & $13 / 81(16.0)$ & $112(27.2)$ \\
\hline \multicolumn{4}{|l|}{ Time of day, No. (\%), $n=422$} \\
\hline Day & $13 / 62(21.0)$ & $42 / 162(25.9)$ & 224 (53.1) \\
\hline Evening/night & $8 / 69 \quad(11.6)$ & $37 / 129(28.7)$ & 198 (46.9) \\
\hline
\end{tabular}

Scenario 1 indicates system activated 0 responders; scenario 2, system activated with $\geq 1$ responder.

\section{Contribution of the responder to survival in different situations}

Figures 2(a)-(d), and Table 1 display the percentages of survival until discharge within strata of victims according to whether the OHCA was witnessed (yes or no), the location (inside vs outside the home), arrival time of the first ambulance $(\leq 6,7-10$ or $\geqslant 11 \mathrm{~min})$ and time of day (08:00-18:00 vs 18:00-08:00). Table 2 shows stratum-specific and interaction odds ratios. The data show that the system leads to survival benefit within all strata except for the subgroup of non-witnessed arrests. 


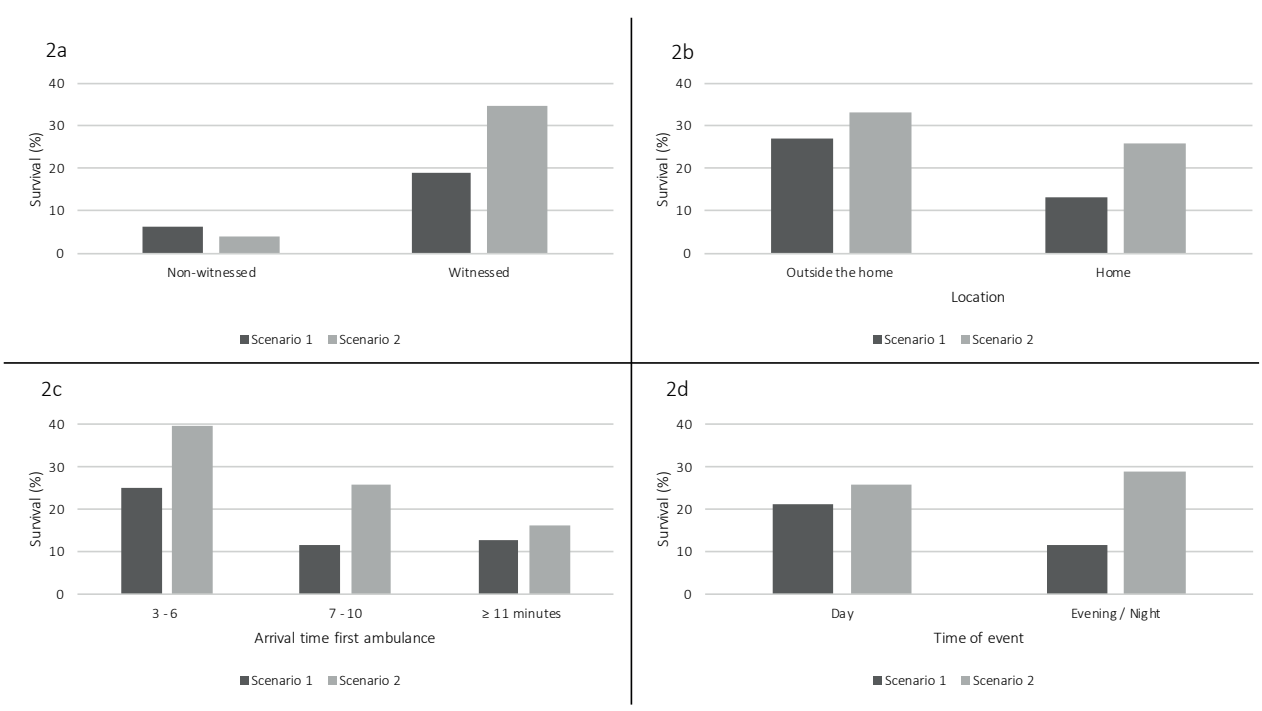

Fig. 2. Percentages of survivors in the cardiopulmonary resuscitation (CPR) groups among the subgroups. Scenario 1 indicates the system activated no responders; Scenario 2 indicates the system activated with $\geq 1$ responder.

Table 2. Relative risk estimates and interaction odds ratios (ORs) of survival at hospital discharge in scenario 2 according to witnessed arrest (yes or no), location, time until arrival of first ambulance and period of the day.

\begin{tabular}{|c|c|c|c|c|}
\hline Setting & $\begin{array}{l}\text { Stratum specific OR } \\
\text { (95\% C.I.) }\end{array}$ & $P$-value & $\begin{array}{l}\text { Interaction OR } \\
\text { (95\% C.I.) }\end{array}$ & $P$-value \\
\hline \multicolumn{5}{|l|}{ Witnessed } \\
\hline No & $0.64 \quad(0.10-4.05)$ & .638 & 1.00 (reference) & - \\
\hline Yes & $2.25 \quad(1.27-4.00)$ & .005 & $3.51 \quad(0.51-24.07)$ & .202 \\
\hline \multicolumn{5}{|l|}{ Location } \\
\hline Outside the home & $1.36(0.47-3.89)$ & .570 & 1.00 (reference) & - \\
\hline Home & $2.28 \quad(1.21-4.28)$ & .011 & $1.68(0.49-5.73)$ & .410 \\
\hline \multicolumn{5}{|l|}{ Arrival times } \\
\hline$\leq 6 \min$ & $1.96(0.81-4.73)$ & .137 & 1.00 (reference) & - \\
\hline $7-10 \min$ & $2.63(1.09-6.35)$ & .032 & $1.34(0.39-4.69)$ & .642 \\
\hline$\geq 11 \mathrm{~min}$ & $1.29(0.39-4.31)$ & .679 & $0.66(0.15-2.94)$ & .585 \\
\hline \multicolumn{5}{|l|}{ Period of the day } \\
\hline Day & $1.32(0.65-2.67)$ & .441 & 1.00 (reference) & - \\
\hline Evening/Night & $3.07 \quad(1.34-7.03)$ & .008 & $2.33(0.78-6.91)$ & .129 \\
\hline
\end{tabular}

C.I., confidence interval. 


\section{Witnessed and non-witnessed arrests}

In both scenarios, witnessed arrests were associated with a better survival probability compared to non-witnessed OHCA (Table 1). In the presence of volunteers the survival rate of witnessed OHCA increased from 19.2\% (Scenario 1) to 34.9\% (Scenario 2) corresponding with an $\mathrm{OR}=2.25(95 \% \mathrm{Cl}: 1.27-4.00 ; P=.005)$. During a non-witnessed arrest the attendance of volunteers was not associated with gain in survival (Table 1) corresponding with an OR=0.64 (95\% Cl: $0.10-4.05 ; P=.638)$. The OR for interaction is 3.51 (95\% Cl: $0.51-24.07)$ meaning that the survival benefit due to the volunteer system is 3.5 times higher for witnessed arrests than for non-witnessed arrests. The $P$-value for interaction is .202.

\section{Location of the arrest}

As expected, the system was mainly activated in cases occurring in the home (348/422) but activation also occurred in 74 cases outside the home. For both Scenario 1 and Scenario 2 survival was higher outside the home than in the home (Table 1, Figure 2(b)). However, within the home, survival in Scenario 2 almost doubles compared to Scenario 1 (25.9\% vs $13.3 \%)$ whereas outside the home survival in Scenario 2 is not much increased $(33.3 \%$ vs 26.9\%). As depicted in Table 2, stratum-specific relative risk estimates (favouring Scenario 2) were 2.28 (95\% Cl: 1.21-4.28; $P=.011$ ) and 1.36 (95\% Cl: 0.47-3.89; $P=.570)$, respectively. The OR for interaction is $1.68(95 \% \mathrm{Cl}$ : 0.49-5.73) meaning that survival benefit due to the volunteer system is more than 1.5 times higher for arrests occurring in the home than for arrests outside the home. The $P$-value for interaction is .410.

\section{Ambulance arrival times}

With respect to time of arrival of the first ambulance, a trend was found towards lower survival probability with increasing delay. However, survival in Scenario 2 was higher compared to Scenario 1 within each stratum of ambulance arrival time since notification (Table 1). Importantly, in Scenario 2 the decrease in survival with increasing delay was less substantial than in Scenario 1 (Figure 2(c)).

Strong effects of the system on survival were observed for cases where the first ambulance arrived with slight delay. The relative risk estimate associated with a 7-10 min interval between notification and arrival of the ambulance was $2.63(95 \% \mathrm{Cl}: 1.09-6.35 ; P=.032)$. The volunteer system is especially effective when the ambulance arrives with a slight delay (7-10 $\mathrm{min}$ ) as indicated by the OR for interaction of 1.34 . When the delay increases to $11 \mathrm{~min}$ or more there is still survival advantage in Scenario 2 compared to Scenario 1, 16\% vs $12.9 \%$ respectively, but the stratum-specific OR of 1.29 (Table 2 ) is no longer statistically significant $(P=.679)$.

\section{Time of the day}

When no volunteers attended (Scenario 1) survival was higher during daytime $(21.0 \%)$ than at evening/night (11.6\%). In the presence of volunteers (Scenario 2) survival percentages 
were higher than in Scenario 1 and at evening/night survival was even slightly higher than during the day (28.7\% and $25.9 \%$ respectively), as depicted in Table 1.

The decrease in survival of arrests during evening/night in Scenario 1 combined with the slight increase in survival in Scenario 2 is consistent with a stratum specific OR=3.07 (95\% $\mathrm{Cl}$ : 1.34-7.03; $P=.008)$, favouring Scenario 2. During daytime the contribution to survival was lower with $\mathrm{OR}=1.32(95 \% \mathrm{Cl}$ : 0.65-2.67; $P=.441)$. The interaction $\mathrm{OR}$ was 2.33 with $P=.129$ which indicated that the benefit of the system during the evening/night is 2.33 times higher compared to the benefit during daytime.

\section{Adjustment for potential confounders}

During the evening or night the distribution of ambulance arrival times differs from that during the day with a higher frequency of longer delays. Distribution of the other effect modifiers (presence of witness and location) may also be different. For this reason, multivariable logistic regression analyses were performed including scenario, all effect modifiers and their terms for interaction with scenario. Age and sex as potential confounders were also added to the model. These analyses gave similar results (not shown).

\section{Discussion}

Recently we reported that survival to hospital discharge in resuscitated out-of-hospital (presumed) cardiac arrest substantially increases by the involvement of citizen responders notified by the ambulance dispatch centre by a text message. In the current study, the hypotheses were tested that the system was especially effective in (a) witnessed OHCA, (b) in the home situation, (c) at longer ambulance delay times and (d) during the evening/nighttime.

\section{Main findings}

It was found that the contribution of the system was most pronounced if the OHCA was witnessed $(O R=2.25)$, occurred in the home situation ( $O R=2.28)$, when the ambulance arrived with a slight delay i.e. 7-10 $\mathrm{min}(\mathrm{OR}=2.63)$ and when the OHCA occurred at evening/night $(\mathrm{OR}=3.07)$. After adjustment for other effect modifiers, age and gender, results were similar.

\section{Witnessed and non-witnessed arrests}

One of the most pronounced predictors of survival is OHCA being witnessed. ${ }^{5}$ Also, in this study witnessed arrests had a higher survival probability in both scenarios. The attendance of volunteers in case of a witnessed arrest had an additional positive effect on survival. Volunteers apparently effectively shorten the delay time to start CPR before emergency medical services (EMS) arrival. Unwitnessed arrest carries a poor prognosis anyway and volunteers cannot contribute much to improve this. 


\section{Location of the arrest}

Higher survival in OHCA outside the home is related to the higher probability that the collapse is witnessed and that witnesses and/or bystanders will start CPR before the arrival of an ambulance. In this study we found that OHCAs outside the home were witnessed in $81.1 \%$ of cases and that CPR was started by a witness or bystander in $84.7 \%$. In OHCAs inside the home, these percentages were $73.9 \%$ and $50.0 \%$, respectively. Due to lower survival probability of OHCA inside the home there is considerable potential for an alert system to contribute to survival. Rapid arrival of volunteers can compensate for the longer delay times until the start of resuscitation. The higher survival gain in the home situation is reflected by the results in this study, where the OR of 2.28 in the home situation is higher than the OR of 1.36 for OHCAs occurring outside the home. These results are promising because the large majority of OHCAs occur in the home, supporting the value of this citizen volunteer system.

\section{Ambulance arrival times}

Survival is known to be negatively related to longer arrival times of the ambulance. ${ }^{6,7}$ Optimal gain in survival by the system can therefore be achieved specifically in settings with more delay until the arrival of healthcare professionals; at short first ambulance arrival times, the ambulance could even arrive before the responders. Importantly, as shown in Figure 2(c), the contribution of the system was typically seen at ambulance arrival times between 6-11 min, which occurred in $44.5 \%$ of the cases. Apparently this is the window of opportunity where volunteers contribute mostly to survival. At later arrival times (11 min or later) this benefit and survival decreased, likely due to the overly long time between onset of the arrest and onset of professional care. ${ }^{8}$ Although volunteers can provide good quality CPR, early stabilisation of the patient by the EMS is crucial for survival of an OHCA.

\section{Time of the day}

During daytime, patients in Scenario 2 had a higher probability of survival compared to Scenario 1 (25.9\% vs 21.0\%). This difference was even greater in the evening/night and amounts to $17.1 \%$ ( $28.7 \%$ vs $11.6 \%$, Table 1$)$. These results suggest that gain in survival due to the system is more evident during the evening/night than during the day. There was no difference between the mean number of responders during daytime and evening/night and therefore the gain in survival during night cannot be attributed to better availability and/or preparedness of volunteers during night-time. Instead a lower activation state of the dispatch/ ambulance system and/or less availability of ambulances in the evening/night have to be considered, given the decrease in survival rate in Scenario 1, comparing OHCA at evening/ night with daytime. This possibility is supported by our data showing that during evening/ night the ambulance arrival time $>11$ min was $34.5 \%$ in contrast to $20.6 \%$ during the day $(P<.001)$. During the evening/night the system could therefore more effectively compensate for the longer delay time of the ambulance, and contributed to a higher survival rate. 


\section{Comparison with other community responder systems}

In different countries several strategies exist to involve citizen volunteers to improve survival of out-of-hospital circulatory arrest. Comparable to the Dutch alert system is the Mobile Life Service (MLS) in Stockholm, Sweden. ${ }^{9}$ In Denmark a volunteer-based network of AEDs (accessible to lay persons) is active where the dispatcher guides bystanders to a close by AED. ${ }^{10}$ Also mobile phone applications are used such as the GoodSAM app in the UK, enabling a call to the dispatch centre and alert to nearby registered first aiders. All these systems have in common that they all rely on trained citizen rescuers who are already nearby the $\mathrm{OHCA}$. These trained citizen rescuers can potentially decrease the time between onset of the arrest and time of starting CPR. Every citizen can be a potential rescuer. However, because of the voluntary nature of these systems, it is hard to predict whether volunteers actually will respond to a notification.

Legal issues with regard to the implementation and use of citizen rescuers in case of emergencies differ between countries and should always be explored. To our knowledge up till now no data on their contribution to survival have been published. A previous study in another region in the Netherlands reported that this alert system contributes to earlier defibrillation in sudden cardiac arrest $(\mathrm{SCA})^{11}$ but did not report on survival. Although no outcome data were reported, the benefit of the alert system was suggested by a reduced time to defibrillation by citizen responders with AEDs, compared to time to defibrillation by the EMS.

\section{Limitations}

A limitation of the study is the small sample size within specific subgroups that likely resulted in limited power to detect significant interaction. Nevertheless, lack of significance does not indicate absence of interaction and the higher contribution to survival of the alert system in the case of witnessed arrests, in the home, in situations with some delay in arrival of the first ambulance and during the evening/night, is consistent with the a priori hypotheses.

\section{Conclusion}

The contribution of the system to survival of OHCA is most pronounced when OHCAs are witnessed, occur in the home, the ambulance arrives with a delay between 6-11 minutes and the OHCA occurs in the evening or night. Taking only the witnessed arrests into account, the majority of the OHCAs $(92.7 \%)$ occurred in at least one of the three other conditions (in the home, a delay between 6-11 min or in the evening), indicating that many OHCA victims can benefit from the system. 


\section{Acknowledgements}

The authors are greatly indebted to the Province Limburg and the Mercurius Foundation for the financial support of this study; FW Lindemans and HJJ Wellens for their support and suggestions; the staff of the participating hospitals, other institutions and medical students for helping in collecting the data: Zuyderland Hospital Sittard/Heerlen; D van Kraaij, H Kragten and the R\&D Cardiology; Laurentius Hospital Roermond, C Werter and M Janssen; Sint Jans Gasthuis Weert, H Klomps and Viecuri Venlo; the emergency medical services of GGD South-Limburg (N Otten) and AmbulanceZorg Limburg-North (L Triepels), Hartslagnu and Ocean (Theo Schrijnemaekers); police department district Limburg South, AED solutions (R Henderikx), BHV-competent (J Hoofs), Vivon (M van Gorp †). Last, but not least, all volunteers helping to increase survival of their fellow citizens with OHCA are gratefully acknowledged.

\section{Conflict of interest}

The authors declare that there is no conflict of interest.

\section{Funding}

This work was supported by the Province Limburg (SAS-202-01794) and the Mercurius Foundation (30957210N). 


\section{References}

1. Pijls RW, Nelemans PJ, Rahel BM and Gorgels AP. A text message alert system for trained volunteers improves out-of-hospital cardiac arrest survival. Resuscitation. 2016;105:182-7.

2. Jacobs I, Nadkarni V, Bahr J, et al. Cardiac arrest and cardiopulmonary resuscitation outcome reports: update and simplification of the Utstein templates for resuscitation registries: a statement for healthcare professionals from a task force of the International Liaison Committee on Resuscitation (American Heart Association, European Resuscitation Council, Australian Resuscitation Council, New Zealand Resuscitation Council, Heart and Stroke Foundation of Canada, InterAmerican Heart Foundation, Resuscitation Councils of Southern Africa). Circulation. 2004;110:3385-97.

3. Peberdy MA, Cretikos M, Abella BS, et al. Recommended guidelines for monitoring, reporting, and conducting research on medical emergency team, outreach, and rapid response systems: an Utstein-style scientific statement: a scientific statement from the International Liaison Committee on Resuscitation (American Heart Association, Australian Resuscitation Council, European Resuscitation Council, Heart and Stroke Foundation of Canada, InterAmerican Heart Foundation, Resuscitation Council of Southern Africa, and the New Zealand Resuscitation Council); the American Heart Association Emergency Cardiovascular Care Committee; the Council on Cardiopulmonary, Perioperative, and Critical Care; and the Interdisciplinary Working Group on Quality of Care and Outcomes Research. Circulation. 2007;116:2481-500.

4. Perkins GD, Jacobs IG, Nadkarni VM, et al. Cardiac arrest and cardiopulmonary resuscitation outcome reports: update of the Utstein Resuscitation Registry Templates for Out-of-Hospital Cardiac Arrest: a statement for healthcare professionals from a task force of the International Liaison Committee on Resuscitation (American Heart Association, European Resuscitation Council, Australian and New Zealand Council on Resuscitation, Heart and Stroke Foundation of Canada, InterAmerican Heart Foundation, Resuscitation Council of Southern Africa, Resuscitation Council of Asia); and the American Heart Association Emergency Cardiovascular Care Committee and the Council on Cardiopulmonary, Critical Care, Perioperative and Resuscitation. Circulation. 2015;132:1286-300.

5. Cummins RO, Eisenberg MS, Hallstrom AP and Litwin PE. Survival of out-of-hospital cardiac arrest with early initiation of cardiopulmonary resuscitation. Am J Emerg Med. 1985;3:114-9.

6. Lyon RM, Cobbe SM, Bradley JM and Grubb NR. Surviving out of hospital cardiac arrest at home: a postcode lottery? Emerg Med J. 2004;21:619-24.

7. Yasunaga $\mathrm{H}$, Miyata $\mathrm{H}$, Horiguchi $\mathrm{H}$, et al. Population density, call-response interval, and survival of out-of-hospital cardiac arrest. Int J Health Geogr. 2011;10:26.

8. Wibrandt I, Norsted K, Schmidt $\mathrm{H}$ and Schierbeck J. Predictors for outcome among cardiac arrest patients: the importance of initial cardiac arrest rhythm versus time to return of spontaneous circulation, a retrospective cohort study. BMC Emerg Med. 2015;15:3.

9. Ringh M, Fredman D, Nordberg P, Stark T and Hollenberg J. Mobile phone technology identifies and recruits trained citizens to perform CPR on out-of-hospital cardiac arrest victims prior to ambulance arrival. Resuscitation. 2011;82:1514-8. 
10. Hansen CM, Lippert FK, Wissenberg M, et al. Temporal trends in coverage of historical cardiac arrests using a volunteer-based network of automated external defibrillators accessible to laypersons and emergency dispatch centers. Circulation. 2014;130:1859-67.

11. Zijlstra JA, Stieglis R, Riedijk F, Smeekes M, van der Worp WE and Koster RW. Local lay rescuers with AEDs, alerted by text messages, contribute to early defibrillation in a Dutch out-of-hospital cardiac arrest dispatch system. Resuscitation. 2014;85:1444-9. 


\section{Chapter 4}

\section{Circumstances and causes of}

sudden circulatory arrests in

the Dutch province of Limburg and the involvement of citizen rescuers

Ruud W.M. Pijls, Patty J. Nelemans, Braim M. Rahel, Anton P.M. Gorgels 


\section{Abstract}

\section{Background}

Recently we showed that a citizen volunteer system using text message alerts improves survival of out-of-hospital sudden circulatory arrest (OHCA) of cardiac origin. It is important to characterise the OHCA population encountered by the volunteers regarding circumstances and causes of the arrests.

\section{Methods and Results}

Eligible for this study were 968 OHCAs that occurred between April 2012 and April 2014 in the Dutch province of Limburg. The distribution of causes of OHCA, patient characteristics and resuscitation settings were compared between 492 arrests wherein volunteers were notified and 476 arrests where the dispatcher decided not to do so.

In case of notification, the cause of OHCA was known in 345 cases and of cardiac origin (treatable) in $83.2 \%(287 / 345)$. About $41 \%$ of the cardiac arrests were caused by acute or chronic coronary artery disease. OHCA occurred within the home environment in about $84 \%$. The OHCA was witnessed in $75 \%$ of the cases. In $60.9 \%$ of the cases a witness or bystander had already started basic life support. However, in approximately $18 \%$ of the OHCAs the volunteer was the first to start basic life support before arrival of the ambulance. In about $75 \%$ of the OHCAs the ambulance arrived at 6 minutes or later after time of notification by the dispatch centre.

\section{Conclusion}

The volunteer system is predominantly activated in situations for which it was developed; cases with cardiac aetiology (58\%) and cases in the home environment (84\%). The majority of patients encountered by the volunteers had 'hearts too good to die', underscoring the benefit of deploying citizen rescuers in programs to improve survival of OHCA. 


\section{Introduction}

Recently we described that a novel citizen volunteers alert system significantly contributes to survival of out-of-hospital circulatory arrest (OHCA) of cardiac origin. ${ }^{1}$ The contribution of the alert system to survival is most substantial in witnessed arrest, within the home environment, at slightly delayed arrival of the first ambulance and during the evening/night. ${ }^{2}$ The zip-code based system was developed especially for OHCA within the home environment, enabling the dispatch centre to alert trained citizen rescuers simultaneously with the ambulances. Involving citizens as first responders in resuscitation of cardiac arrest, imposes them with a large responsibility. It is therefore crucial to study whether they indeed encounter emergency cases with a reasonable chance to actually provide substantial support. This depends mainly on the details of the resuscitation scenario and the causes of the OHCA. It is therefore important to explore if the volunteers are notified especially for resuscitation settings within the home situation and for help for OHCAs with a cardiac cause. This study aims to verify that the alert system is deployed in conditions for which it was initially developed by providing a description of the circumstances and causes of OHCAs, specifically where the citizen volunteers are involved.

\section{Methods}

\section{Setting}

We used data from a prospective registry consisting of all OHCAs in the Dutch province of Limburg (an area of approximately $2153 \mathrm{~km}^{2}\left(831 \mathrm{mi}^{2}\right)$ with 1.12 million inhabitants) during the period April 2012 to April 2014. Utstein recommendations and definitions were used. ${ }^{3-5}$ The medical ethics committee of the Maastricht University Medical Centre approved the study (project number 114029).

\section{Resuscitation volunteer network in the study region}

As outlined elsewhere ${ }^{1}$, the basic professional procedure for an OHCA in the Netherlands consists of dispatching two ambulances to the scene, both manned by a paramedic and a basic life support (BLS)/automated external defibrillator (AED) trained driver, equipped with a defibrillator and requirements to provide advanced life support. Furthermore, the dispatch centralist can choose to activate the citizen volunteer system, a system where certified BLS/ AED volunteers are notified by a text message. The dispatch centralist does not activate the system if the ambulance is already nearby or present at the scene, if the OHCA occurs in a (closed) public place with an on-site AED (such as shopping malls, sport venues etc.), if the OHCA is evidently of a non-cardiac aetiology or if the need for resuscitation is not recognised. The system uses the zip codes of the location of the victim and citizen rescuers to determine which volunteers are possibly closest to the victim, at least within a radius of $1 \mathrm{~km}(0.62$ mile). In a 1:2 fashion, selected volunteers are notified to either go to the victim immediately 
or collect a system-registered AED first. To ensure a sufficient, but not excessive, number of volunteers, a maximum of 30 citizen rescuers are notified.

At the time of the study, 17 of the 24 dispatch centres in the Netherlands were using the system. In Limburg, both dispatch centres were active with a total of $>9000$ volunteers (8.3/1000 inhabitants).

\section{Data collection}

We retrieved data from the following sources: 1. the dispatch centres from Limburg North and South, 2. their respective emergency medical services, 3. notified volunteers, 4. alert system organisation (Hartslagnu), 5. the six hospitals in Limburg, and 6. AED providers.

All notified volunteers received a questionnaire to obtain information about their attendance and, if applicable, about details of the resuscitation scenario. Medical history and postresuscitation treatment were provided by the six hospitals in Limburg.

We assessed causes of OHCAs using information mostly from hospital records and discharge reports, autopsy reports, as well as from written information from the dispatch centre and ambulance personnel. All diagnoses were confirmed by one of the authors, a senior cardiologist (A.G.).

\section{Definitions}

Acute coronary syndromes were cases with documented ST-elevation myocardial infarction or non-ST-elevation myocardial infarction. Cases with previous coronary revascularisation or old myocardial infarction were diagnosed as chronic coronary artery disease. Electrical heart diseases included tachycardia, mostly of ventricular origin; bradycardia, either unspecified or due to sinus bradycardia or atrioventricular block, or genetic forms such as Wolff-ParkinsonWhite, Brugada or long QT-syndrome. Structural heart disease consisted mostly of cases with hypertrophic or dilated cardiomyopathy. The diagnosis exsanguination included cases such as ruptured dissection/aneurysm or gastrointestinal bleed, and asphyxia was diagnosed in cases with respiratory insufficiency, pulmonary embolism or suffocation, mostly by choking.

\section{Statistical analysis}

The distribution of causes of OHCA, patient characteristics and resuscitation settings were evaluated in the group of OHCAs in which the system was activated and compared with distribution in the group of OHCAs in which the system was not activated. Categorical variables were described as absolute numbers and percentages, and continuous variables as means with standard deviation or medians with interquartile range. The chi-square test was used to test for statistically significant differences in proportions between groups. For comparison of differences in continuous variables the $t$-test for independent samples or the Mann-Whitney $U$ test were used.

We used the statistical software package of SPSS (SPSS for Windows, version 22.0, SPSS Inc., Chicago, IL) to analyse the data. 


\section{Results}

During the 24 months study period, 1546 OHCAs were recorded. There were 461 victims with prolonged death and a resuscitation setting was present in 1085 victims (including noncardiac arrests and cases with a do-not-resuscitate policy). Arrests within the ambulance occurred in 32 instances. A total of 85 OHCAs occurred in closed public places with an onsite AED and local trained rescuers. Therefore, 968 cases were included for evaluation of causes of OHCA, patient characteristics and resuscitation settings in the OHCA population as encountered by the citizen rescuers. The system was activated in 492 arrests $(50.8 \%)$ and not activated in 476 arrests (49.2\%), as depicted in Fig. 1.

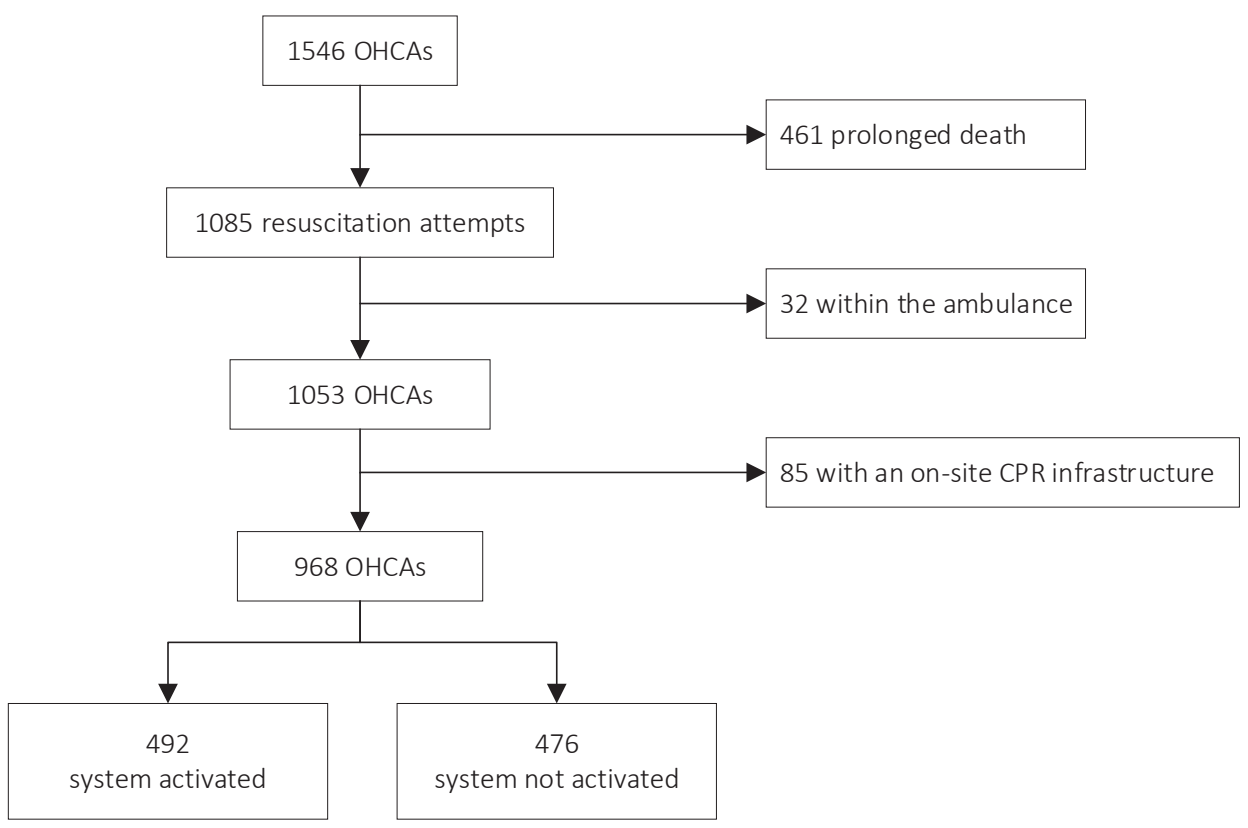

Fig. 1. Flowchart of patient inclusion. OHCA indicates out-of-hospital circulatory arrest; CPR, cardiopulmonary resuscitation.

\section{Involvement of text message responders}

Table 1 shows the baseline characteristics per scenario (activated versus not activated). The mean age of patients with OHCAs in which the system was activated was $67.9( \pm 14.1)$ and around $70 \%$ was male, similar to the distribution of age and sex in OHCAs in which the system was not activated.

Regarding circumstances of OHCAs, citizen rescuers were more frequently involved in OHCAs within the home environment compared with resuscitations outside the home $(83.9 \%$ vs 
66.1\%). A witness and/or bystander had already started resuscitation in $60.9 \%$ of cases (versus $41 \%$ in arrests where no volunteers were involved) and in approximately $18 \%$ the volunteers were the first to start BLS. The initial rhythm was shockable in $50 \%$ (versus $40.3 \%$ in arrests without involvement of volunteers) and in the former group also more frequently a shock was delivered.

Table 1 Population and resuscitation characteristics among the two different CPR scenarios.

\begin{tabular}{llll}
\hline Total & Activated & Not activated $P$-value \\
$N=968$ & $N=492$ & $N=476$
\end{tabular}

\section{Demographic variables}

$\begin{array}{lllllllll}\text { Age, mean (SD), years, } n=966 & 67.1 & ( \pm 15.4) & 67.9 & ( \pm 14.1) & 66.2 & ( \pm 16.6) & .088 \\ \text { Gender, male, No. }(\%), n=968 & 666 & (68.8) & 347 & (70.5) & 319 & (67.0) & .238\end{array}$

\section{Resuscitation variables}

$\begin{array}{llllllll}\begin{array}{l}\text { Location of the arrest, No. (\%), } n=967 \\ \quad \text { At home }\end{array} & 727 & (75.2) & 413 & (83.9) & 314 & (66.1) & \\ \quad \text { Outside home } & 240 & (24.8) & 79 & (16.1) & 161 & (33.9) & \\ \text { Witness, yes, No. (\%), } n=968 & 748 & (77.3) & 369 & (75.0) & 379 & (79.6) & .086 \\ \text { BLS started by, No. (\%), } n=959 & & & & & & & <.001 \\ \quad \text { Witness } & 297 & (31.0) & 178 & (36.5) & 119 & (25.3) & \\ \quad \text { Bystander } & 193 & (20.1) & 119 & (24.4) & 74 & (15.7) & \\ \text { EMS } & 319 & (33.3) & 75 & (15.4) & 244 & (51.8) \\ \quad \text { TM responder } & 86 & (9.0) & 86 & (17.6) & 0 & (0.0) & \\ \text { First responder }^{\text {a }} & 60 & (6.3) & 30 & (6.1) & 30 & (6.4) & \\ \text { None }^{\text {b }} & 4 & (0.4) & 0 & (0.0) & 4 & (0.8) & \end{array}$

\section{Ambulance times}

Time until arrival of first ambulance, $n=953$

$\begin{array}{lllllllll}\leq 6 \text { minutes } & 217 & (22.8) & 128 & (26.6) & 89 & (18.9) & \\ 7-8 \text { minutes } & 234 & (24.6) & 116 & (24.1) & 118 & (25.1) & \\ 9-10 \text { minutes } & 227 & (23.8) & 105 & (21.8) & 122 & (25.9) & \\ \geq 11 \text { minutes } & 275 & (28.9) & 133 & (27.6) & 142 & (30.1) & \\ \text { Shock delivered, No. (\%), } n=968 & 512 & (52.9) & 278 & (56.5) & 234 & (49.2) & .022\end{array}$

CPR cardiopulmonary resuscitation, SD standard deviation, BLS basic life support, EMS emergency medical system, $T M$ text message

First respondera: On-duty police or firefighter notified to go to the resuscitation scene.

None ${ }^{b}$ : Patients not being resuscitated because of a do-not-resuscitate policy.

Regarding the clinical setting of the OHCAs: in both study groups the majority of cases were found to have no cardiovascular history, thus the arrest being the first manifestation of cardiovascular disease.

In cases where the system was activated, the first ambulance arrived within 6 minutes in a mere $25 \%$ of cases. Delay between 6-11 minutes was recorded in approximately $50 \%$ and 
delay exceeding 11 minutes in approximately 25\%. In the non-activated group the arrival times are unreliable because frequently the ambulance was already heading to the case before upscaling to the highest level of emergency due to the OHCA occurring during the ride.

Because the system was developed particularly for the treatment of arrests with a cardiac cause, we studied the distribution of causes among the two different scenarios. As expected, we found that citizen rescuers were more frequently involved in OHCAs with a cardiac cause and less frequently in cases with a non-cardiac cause. Cases were classified as unknown (251 cases in total), mostly when patients died before hospital arrival and no sufficient diagnostic information could be obtained.

Information on cardiac and non-cardiac causes is listed in table 2. Basically, there were no differences in the distribution of causes between the activated and the non-activated group. The cause of the arrest was known in 345 and 372 cases in the activated and non-activated group, respectively. In $83.2 \%$ (287/345) of cases, volunteers were confronted with OHCAs with a cardiac cause, many being treatable. In a mere $16.8 \%$ (58/345), the OHCA was noncardiac. These proportions were $67.5 \%$ (251/372) and 32.5\% (121/372) without activation of the system.

Acute $(33.4 \%)$ and chronic (7.7\%) coronary artery disease were the most common cardiac causes. Heart failure was noted in $12.9 \%$. In $35.5 \%$, the initial rhythm was ventricular tachycardia (VT)/ventricular fibrillation (VF) unspecified, mostly patients who died at the scene and no further diagnostic information being available. Electrical and structural heart diseases were encountered by volunteers in 10.5\% (30/287) of the cardiac cases versus $14 \%$ in the non-activated group.

In the 58 cases with a non-cardiac cause in which volunteers were involved, asphyxia (44.8\%) was the most frequent cause and exsanguination was diagnosed in 13.8\%. Trauma, drug overdoses and suicide were less likely to occur in the activated group and there was no resuscitation caused by submersion. Around 30\% of the non-cardiac cases in the activated group had other underlying causes such as cerebral accidents or sepsis. In three cases in both groups the initial rhythm was pulseless electrical activity (PEA)/asystole, but the underlying causes could not be determined. 
Table 2. Distribution of specific causes ${ }^{\mathrm{a}}$ among the two different CPR scenarios.

\begin{tabular}{|c|c|c|c|c|c|c|c|}
\hline \multirow[b]{2}{*}{ Cardiac cause, No. (\%) } & \multicolumn{2}{|c|}{$\begin{array}{l}\text { Total } \\
N=717\end{array}$} & \multicolumn{2}{|c|}{$\begin{array}{l}\text { Activated } \\
N=345\end{array}$} & \multicolumn{2}{|c|}{$\begin{array}{l}\text { Not activated } \\
N=372\end{array}$} & \multirow{2}{*}{$\begin{array}{l}\boldsymbol{P} \text {-value } \\
.526\end{array}$} \\
\hline & 538 & $(100)$ & 287 & $(100)$ & 251 & $(100)$ & \\
\hline Acute coronary syndrome & 187 & $(34.8)$ & 96 & $(33.4)$ & 91 & $(36.3)$ & \\
\hline Chronic coronary artery disease & 44 & $(8.2)$ & 22 & $(7.7)$ & 22 & $(8.8)$ & \\
\hline Heart failure & 62 & (11.5) & 37 & (12.9) & 25 & $(10.0)$ & \\
\hline Electrical heart disease & 42 & $(7.8)$ & 18 & (6.3) & 24 & $(9.6)$ & \\
\hline Structural heart disease & 23 & $(4.3)$ & 12 & $(4.2)$ & 11 & $(4.4)$ & \\
\hline VT/VF unspecified & 180 & (33.5) & 102 & $(35.5)$ & 78 & (31.1) & \\
\hline Non-cardiac cause, No. (\%) & 179 & $(100)$ & 58 & $(100)$ & 121 & $(100)$ & .405 \\
\hline Trauma & 16 & $(8.9)$ & 1 & $(1.7)$ & 15 & $(12.4)$ & \\
\hline Submersion & 1 & $(0.6)$ & 0 & (0.0) & 1 & $(0.8)$ & \\
\hline Drug overdoses & 4 & $(2.2)$ & 1 & $(1.7)$ & 3 & $(2.5)$ & \\
\hline Asphyxia & 78 & $(43.6)$ & 26 & (44.8) & 52 & (43.0) & \\
\hline Exsanguination & 21 & (11.7) & 8 & (13.8) & 13 & (10.7) & \\
\hline Suicide & 7 & (3.9) & 3 & $(5.2)$ & 4 & (3.3) & \\
\hline Other $^{b}$ & 46 & (25.7) & 16 & $(27.6)$ & 30 & (24.8) & \\
\hline PEA/asystole unspecified & 6 & $(3.4)$ & 3 & $(5.2)$ & 3 & $(2.5)$ & \\
\hline
\end{tabular}

CPR cardiopulmonary resuscitation, PEA pulseless electrical activity, VT ventricular tachycardia, VF ventricular fibrillation

a In 251 cases the cause was unknown and therefore these cases are not included in this table.

${ }^{b}$ Other includes cases such as cerebral causes or sepsis.

\section{Discussion}

\section{Main findings}

A population-based survey including all consecutive OHCAs showed that the majority of cases involving volunteers had a cardiac cause. In about $17 \%$ of cases with known aetiology, cardiopulmonary resuscitation (CPR) was needed after a collapse due to a non-cardiac cause. Treatable causes such as acute coronary syndrome was the most common cardiac cause. Around $60 \%$ of cases did not have a cardiovascular history, the arrest being the first manifestation of cardiac disease. This implies a good prognosis after successful resuscitation in the majority of patients, a feature already characterised in the early nineteen sixties as patients with 'hearts too good to die'. ${ }^{6}$

\section{Study population and involvement of the text message volunteer}

The system has been shown to increase survival in cardiac arrests if at least one volunteer responded. ${ }^{1}$ In a minority of cases volunteers are notified for non-cardiac arrests, mostly due to asphyxia. In this situation, the involvement of volunteers could also be lifesaving by applying the Heimlich manoeuvre. Expectedly, volunteers are rarely confronted with traumarelated OHCA because centralists are instructed not to activate the system if the OHCA is obviously caused by trauma. 
Zip code information about the resuscitation location is needed to activate the system, therefore OHCA occurring within the home environment was predominant (occurring in about 8 of 10 cases). Especially here support is needed not only because of the frequent occurrence of OHCA at home but also because of the more frequent absence of adequate CPR capabilities in that situation. Given its substantial contribution to survival, this system can be viewed as a new link in the chain of survival.

In about $60 \%$ of the cases a witness or bystander had already started BLS. Therefore, the system is helpful in supporting lay providers faced with an OHCA situation. In 18\% of cases the volunteers were the first to start BLS. Although volunteers are BLS/AED certified, quick arrival of the emergency medical services is mandatory. In over $75 \%$ of cases, the ambulance arrival time exceeded 6 minutes, underscoring the importance of this system as a bridge to professional help. This is also supported by the higher percentage of shockable rhythms with involvement of the citizen rescuers, likely due to high quality BLS, helping to sustain VT/VF, rather than this to deteriorate in asystole. ${ }^{7}$

In $42 \%$ of the OHCAs a volunteer alert would have been appropriate, but the alert system was not activated. The reasons why are currently being studied and are likely due to circumstances such as: the ambulance was already nearby or present at the scene, the OHCA occurred in an enclosed public place with an on-site AED, the OHCA was of a non-cardiac aetiology or the need for resuscitation was not recognised.

\section{Strengths and limitations}

The strength of our study is that it concerns a population-based survey, performed in a well-defined geographical area, including all consecutive OHCA cases during a 2-year period. Although we tried to obtain accurate information from the notified volunteers by use of a questionnaire, it was practically impossible, due to the rapidly changing nature of a resuscitation setting, to retrieve exact numbers of responders and their arrival times at the location.

From the hospital records we could assess the medical history and the cause of the cardiac arrests of those being admitted to the hospital. This was not possible in 251 cases because these patients died at the scene. This limitation is of course inherent to a medical emergency occurring outside the hospital and with a low survival rate.

\section{Conclusion}

The majority of OHCAs encountered by volunteers occur in the home environment, have a cardiac cause and involve 'hearts too good to die', underscoring the benefit of deploying citizen rescuers in programs to improve survival of OHCA. 


\section{Acknowledgements}

We are greatly indebted to the Province Limburg and the Mercurius Foundation for the financial support of this study; F.W. Lindemans and H.J.J. Wellens for their support and suggestions; the staff of the participating hospitals, other institutions and medical students for helping in collecting the data: Zuyderland hospital Sittard/Heerlen; D. van Kraaij, H. Kragten and the R\&D Cardiology; Laurentius hospital Roermond, C. Werter and M. Janssen; Sint Jans Gasthuis Weert, H. Klomps, and Viecuri Venlo; the emergency medical services of the GGD SouthLimburg (N. Otten) and AmbulanceZorg Limburg-North (L. Triepels), Hartslagnu and Ocean (T. Schrijnemaekers); police department district Limburg South, AED solutions (R. Henderikx), BHV-competent (J. Hoofs), Vivon (M. van Gorp ${ }^{+}$) and last but not least, all volunteers helping to increase survival of their fellow citizens with OHCA are gratefully acknowledged.

\section{Funding}

This work was supported by the Province Limburg [SAS-202-01794] and the Mercurius Foundation, Heerlen [30957210N].

\section{Conflict of interest}

R.W.M. Pijls, P.J. Nelemans, A.P.M. Gorgels and B.M. Rahel declare that they have no competing interests. 


\section{References}

1. Pijls RW, Nelemans PJ, Rahel BM and Gorgels AP. A text message alert system for trained volunteers improves out-of-hospital cardiac arrest survival. Resuscitation. 2016;105:182-7.

2. Pijls RW, Nelemans PJ, Rahel BM and Gorgels AP. Factors modifying performance of a novel citizen text message alert system in improving survival of out-of-hospital cardiac arrest. Eur Heart J Acute Cardiovasc Care. 2017:2048872617694675.

3. Jacobs I, Nadkarni V, Bahr J, et al. Cardiac arrest and cardiopulmonary resuscitation outcome reports: update and simplification of the Utstein templates for resuscitation registries: a statement for healthcare professionals from a task force of the International Liaison Committee on Resuscitation (American Heart Association, European Resuscitation Council, Australian Resuscitation Council, New Zealand Resuscitation Council, Heart and Stroke Foundation of Canada, InterAmerican Heart Foundation, Resuscitation Councils of Southern Africa). Circulation. 2004;110:3385-97.

4. Peberdy MA, Cretikos M, Abella BS, et al. Recommended guidelines for monitoring, reporting, and conducting research on medical emergency team, outreach, and rapid response systems: an Utstein-style scientific statement: a scientific statement from the International Liaison Committee on Resuscitation (American Heart Association, Australian Resuscitation Council, European Resuscitation Council, Heart and Stroke Foundation of Canada, InterAmerican Heart Foundation, Resuscitation Council of Southern Africa, and the New Zealand Resuscitation Council); the American Heart Association Emergency Cardiovascular Care Committee; the Council on Cardiopulmonary, Perioperative, and Critical Care; and the Interdisciplinary Working Group on Quality of Care and Outcomes Research. Circulation. 2007;116:2481-500.

5. Perkins GD, Jacobs IG, Nadkarni VM, et al. Cardiac arrest and cardiopulmonary resuscitation outcome reports: update of the Utstein Resuscitation Registry Templates for Out-of-Hospital Cardiac Arrest: a statement for healthcare professionals from a task force of the International Liaison Committee on Resuscitation (American Heart Association, European Resuscitation Council, Australian and New Zealand Council on Resuscitation, Heart and Stroke Foundation of Canada, InterAmerican Heart Foundation, Resuscitation Council of Southern Africa, Resuscitation Council of Asia); and the American Heart Association Emergency Cardiovascular Care Committee and the Council on Cardiopulmonary, Critical Care, Perioperative and Resuscitation. Circulation. 2015;132:1286-300.

6. Beck CS and Leighninger DS. Hearts too good to die--our problem. Ohio State Med J. 1960;56:1221-3.

7. Waalewijn RA, Nijpels MA, Tijssen JG and Koster RW. Prevention of deterioration of ventricular fibrillation by basic life support during out-of-hospital cardiac arrest. Resuscitation. 2002;54:31-6. 


\section{Chapter 5}

Characteristics of a novel citizen rescue system for out-of-hospital cardiac arrest in the Dutch province of Limburg: relation to incidence and survival

Ruud W.M. Pijls, Patty J. Nelemans, Braim M. Rahel, Anton P.M. Gorgels 


\section{Abstract}

\section{Background}

We evaluated the characteristics of a novel text message system notifying citizen rescuers in cases of out-of-hospital circulatory arrest (OHCA) in the Dutch province of Limburg, including their relation to incidence and survival.

\section{Methods and results}

The study area comprised $2153 \mathrm{~km}^{2}\left(831 \mathrm{mi}^{2}\right)$ with 1.12 million inhabitants. During the 2-year study period approximately 9000 volunteers were registered, about 60\% male, 59\% with no experience in actual resuscitation, and $27.4 \%$ healthcare professionals. The system was not activated in 557 of 1085 (51.3\%) OHCAs, frequently because there was no resuscitation setting present yet at the time of the emergency call. Rescuers were notified on 1076 occasions, with no resuscitation setting being present in 548 of 1076 (50.9\%) notifications. OHCA incidence rates were 67 per 100,000 inhabitants per year, 95 per 100,000 men and 39 per 100,000 women standardised for age with the European Standard Population. The mean number of notifications per volunteer was 1.3 times per year. Higher volunteer density was related to increased survival if at least one volunteer attended the cardiac arrest. If the density exceeded $0.75 \%$, survival increased to $34.8 \%$ compared to $20.6 \%$ at a density below $0.25 \%$.

\section{Conclusion}

In about half of OHCAs needing resuscitation the system was activated and in approximately half of the notifications resuscitation proved to be justified. Volunteers are notified 1.3 times per year on average. Survival was related to volunteer density, suggesting that further improvement can be achieved by increasing the number of citizen rescuers. 


\section{Introduction}

In the Netherlands a citizen volunteer alert system was launched to be activated in cases of out-of-hospital circulatory arrest (OHCA). This zip-code-based system substantially contributes to survival following OHCA with a cardiac cause ${ }^{1}$, specifically in the home ${ }^{2}$, where most OHCAs occur.

The activation process has not been described to date. The present study was designed to investigate how frequently the system is activated in cases of OHCA and to identify reasons why the notification system was not activated. We also investigated the mean notification rate per volunteer and if volunteer density has an influence on survival.

\section{Methods}

Included in the study were witnessed and unwitnessed OHCAs in patients of all ages with sudden loss of vital signs, where the ambulance service was notified. Cases occurring in the terminal phase of a disease were excluded.

\section{Setting}

Data were used from an Utstein-based ${ }^{3}$ registry comprising all cases of OHCA in the Dutch province of Limburg during the period April 2012 to April 2014, covering an area of $2153 \mathrm{~km}^{2}$ (831 $\mathrm{mi}^{2}$ ) with 1.12 million inhabitants (MUMC+ approved project number 114029).

\section{Resuscitation volunteer network}

The basic professional procedure during an OHCA in the Netherlands consists of dispatching two ambulances to the resuscitation location. Additionally, a text message (TM) alert system can be activated which in turn will notify certified volunteers trained in providing basic life support (BLS) and the use of an automated external defibrillator (AED). To determine which volunteers and AEDs are possibly closest to the victim within a 1-km (0.62-mi) radius, the system uses the zip codes of the victim, registered volunteers and AEDs. The system aims to select and send a TM to volunteers directing them in a 1:2 fashion either immediately to the victim or to collect a system-registered AED first. To establish an adequate but not excessive number of citizen rescuers, a maximum of 30 volunteers are notified.

During the study, 17 (including both dispatch centres in Limburg) of the 24 dispatch centres in the Netherlands were using the system consisting of approximately 66,500 registered volunteers (about 9000 volunteers in the Dutch province of Limburg).

\section{Data collection}

The following sources were used to retrieve data: (1) the dispatch centres at Limburg North and South; (2) their corresponding emergency medical services (EMS); (3) TM-alert system 
organisation (Hartslagnu); (4) notified volunteers; (5) the six hospitals in Limburg; and (6) AED providers.

Data retrieved from the dispatch centres and corresponding EMS consisted of notification time, ambulance departure time and time of arrival at the location, survival at hospital discharge, and information about the resuscitation scenario (e.g. whether the OHCA was witnessed or not, whether BLS was started and by whom, and whether citizen rescuers attended the OHCA). Alert system information such as the time the TM was sent, the number of volunteers notified and AEDs, and type of notification (immediately start BLS or first obtain an AED) was acquired from the TM-alert system organisation. A questionnaire was sent to all notified volunteers in order to obtain information about their attendance and, if applicable, about details of the cardiopulmonary resuscitation (CPR) scenario. The patient's medical history and post-resuscitation treatment were obtained from the six hospitals in Limburg.

\section{Statistical analysis}

Data of all resuscitated and non-resuscitated OHCA victims in the 2-year study period were used to calculate crude, age-standardised and age- and sex-specific incidence rate per 100,000 inhabitants per year. Information on the number of men and women per 5-year age category in the province of Limburg in 2013 were obtained from Statistics Netherlands (CBS). The European Standard Population was used to calculate age-standardised incidence rates. Categorical variables were described as absolute numbers and percentages, and continuous variables as means with standard deviation or medians with interquartile range.

The statistical software package of SPSS (SPSS for Windows, version 22.0, SPSS Inc, Chicago, IL) was used to analyse the dat

\section{Results}

During the study period, 1546 OHCAs including 461 victims with prolonged death were recorded. Resuscitation was indicated in 1085 cases who were still alive at arrival of one or more volunteers or the ambulance.

\section{Characteristics of citizen rescuers}

During the study period more than 9000 volunteers were registered in Limburg. About 60\% were male, around $59 \%$ had no previous experience in performing resuscitation, $27.4 \%$ were healthcare professionals of whom 51.5\% had a nursing background, 32\% a paramedical profession, $6.4 \%$ being physicians and around $10 \%$ medical students.

\section{Incidence of OHCA}

Based on a total of 1546 OHCAs and prolonged deaths, crude incidence was 69 per 100,000 inhabitants per year, 94 per 100,000 men and 44 per 100,000 women. 
Fig. 1 depicts the age-specific incidence rates of OHCAs per 100,000 for both sexes. Incidence increased up to age group 70-79 and was consistently higher in men. After standardisation for age with the European Standard Population, incidence was 67 per 100,000 inhabitants per year, 95 per 100,000 men and 39 per 100,000 women.

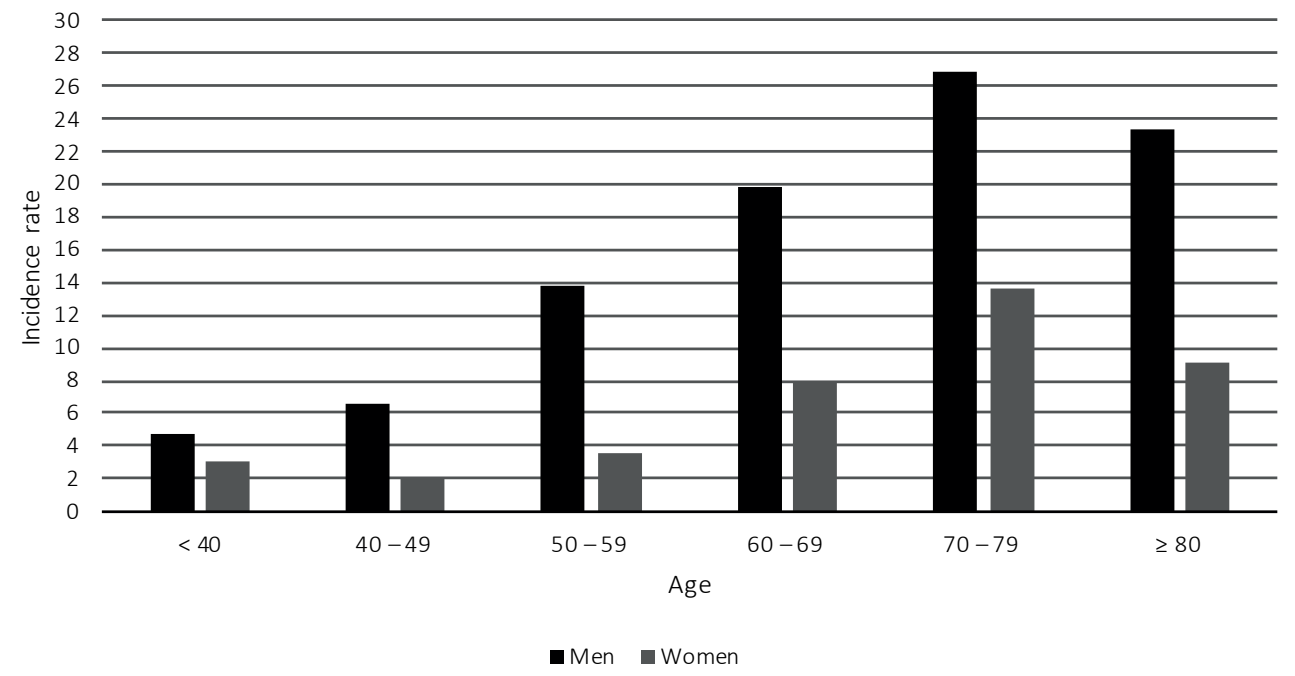

Fig. 1. Sex- and age-specific incidence of OHCAs per 100,000 inhabitants. OHCA indicates out-ofhospital circulatory arrest.

\section{Coverage of the system of patients needing resuscitation}

A total of 1085 OHCAs requiring resuscitation were recorded (Fig. 2). Volunteers were notified in 528 of 1085 OHCAs (48.7\%), 467 (88.4\%) with a cardiac and 61 (11.6\%) with a non-cardiac origin. The reasons for not activating the system were evaluated in a sample of 351 of these 557/1085 cases (Tab. 1 ).

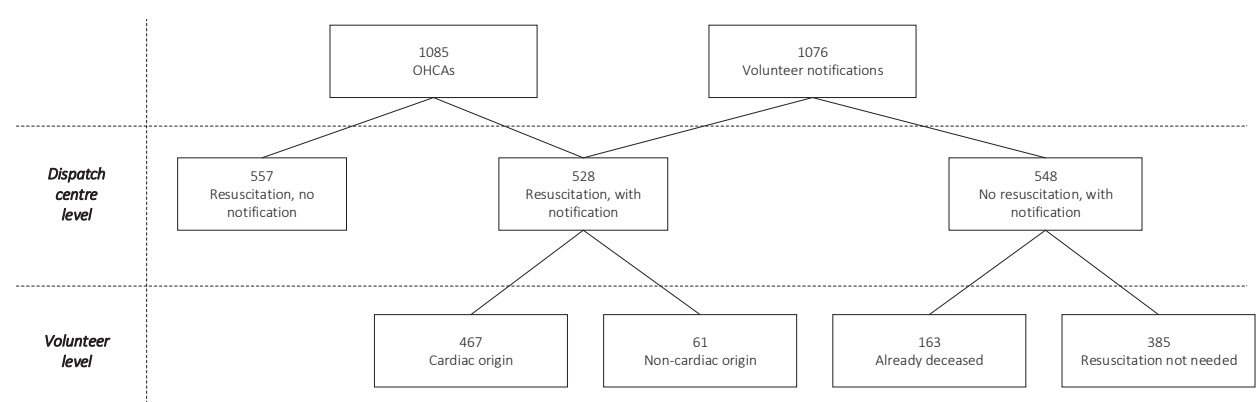

Fig. 2. Flowchart of the 1085 attempted resuscitations and 1076 notifications in relation to the dispatch centre level and volunteer level. OHCA indicates out-of-hospital circulatory arrest. 
Table 1. Reasons for not activating the rescue system.

\begin{tabular}{lll}
\hline Reason & N & (\%) \\
\hline Not yet OHCA setting & 168 & $(47.9)$ \\
Zip code not known & 54 & $(15.4)$ \\
(Semi) medical help already at location & 31 & $(8.8)$ \\
Onsite AED and rescuers at location & 30 & $(8.5)$ \\
Bad prognosis evident & 14 & $(4.0$ \\
OHCA not recognized by dispatcher & 3 & $(0.9)$ \\
Patient with known DNR policy & 3 & $(0.9)$ \\
Other reasons & 14 & $(4.0)$ \\
Reason unknown & 34 & $(9.7)$ \\
\hline
\end{tabular}

$O H C A$ out-of-hospital circulatory arrest, $A E D$ automated external defibrillator, DNR do not resuscitate

a Shooting incidence, inaccessible area etc.

In $47.9 \%$ a condition preceding OHCA, such as chest pain or dyspnoea, evoked the emergency call. So at the moment of the OHCA the ambulance was already heading towards or present at the location. Other reasons were lack of zip-code information of the OHCA location (15.4\%), medical help such as medical staff during a sports event (8.8\%) or local rescuers and AED on site $(8.5 \%)$ already present, evidently poor prognosis $(4.0 \%)$, OHCA not recognised by the dispatcher (0.9\%), known do-not-resuscitate (DNR) policy (0.9\%), other reasons (unspecified) $(4.0 \%)$, no reason identified $(9.7 \%)$.

\section{Frequency of justified volunteer notifications}

Volunteers were notified in 1076 cases (Fig. 2). Of all notifications 528 (49.1\%) concerned actual resuscitations (including DNR and in-ambulance OHCAs). The 548 non-resuscitation settings (Fig. 2) concerned reversible collapses $(n=385)$ due to insults, alcohol intoxication, vagal episodes, pulmonary insufficiency, cerebral accidents or terminal disease, or prolonged deaths ( $n=163$ ).

Based on 1076 notifications (in the 2-year study period) and a mean of 21.9 volunteers notified per case, annual notifications amounted to 11,782 [(1076 ×21.9) / 2]. Given 9000 available volunteers the mean number of annual notifications per volunteer is 1.30 , half $(0.65$ per year) concerning actual resuscitations.

\section{Volunteer density and survival}

The 32 municipalities of the study region were categorised according to number of volunteers/ number of inhabitants as: $<0.25 \%, 0.25-0.49 \%, 0.50-0.74 \%$ and $\geq 0.75$. To evaluate the effectiveness of the system in relation to volunteer density we performed an analysis using 422 cases with OHCA due to a cardiac cause where the system was activated. Patients with a DNR policy and/or cardiac arrest in the ambulance were not included in this analysis, hence 
the difference compared with the 467 cardiac cases in Fig. 2. Within each density category, we compared the percentage survival to hospital discharge when at least one responder attended versus no responder attending. In the latter group, at higher densities no increase in survival was found. When volunteers attended, percentage survival increased with higher volunteer density (Tab. 2; Fig. 3).

Table 2. Percentage survival, gain in survival and proportion OHCA with at least one responder according to volunteer density.

\begin{tabular}{|c|c|c|c|c|}
\hline $\begin{array}{l}\text { Volunteer } \\
\text { percentage of } \\
\text { inhabitants, (\%) }\end{array}$ & $\begin{array}{l}\text { Survival with } \\
\text { no responders } \\
(\%, N)\end{array}$ & $\begin{array}{l}\text { Survival with } \\
\text { at least one } \\
\text { responder }(\%, N)\end{array}$ & Gain in survival (\%) & $\begin{array}{l}\text { OHCA with } \\
\text { at least one } \\
\text { responder }(\%, N)\end{array}$ \\
\hline$<0.25$ & $18.2(6 / 33)$ & $20.6(7 / 34)$ & 2.4 & $51(34 / 67)$ \\
\hline $0.25-0.49$ & $11.8(4 / 34)$ & $15.9(11 / 69)$ & 4.1 & $67(69 / 103)$ \\
\hline $0.50-0.74$ & $17.9(7 / 39)$ & $30.2(29 / 96)$ & 12.3 & 71 (96/135) \\
\hline$\geq 0.75$ & $16.0(4 / 25)$ & $34.8(32 / 92)$ & 18.8 & 79 (92/117) \\
\hline
\end{tabular}

OHCA out-of-hospital circulatory arrest

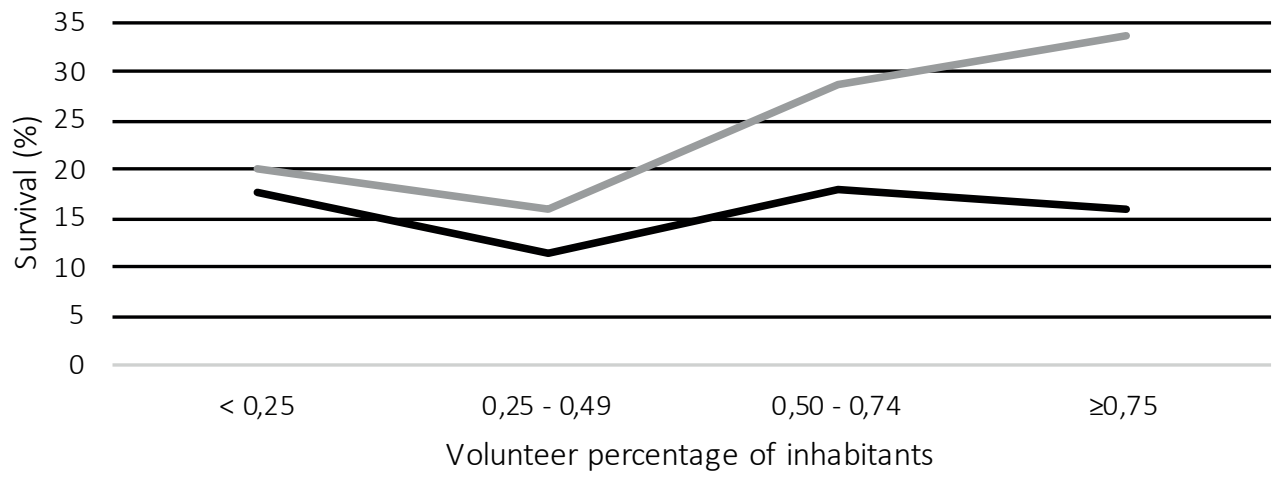

No responders At least one responder

Fig. 3. Gain in percentage survival at discharge from hospital according to volunteers per number of inhabitants. 


\section{Discussion}

\section{Main findings}

In the Dutch province of Limburg with an age-standardised OHCA incidence of 67 per 100,000 inhabitants per year, resuscitation was attempted in 1085 cases within a 2-year period. The system was not activated in 557 (51.3\%) cases, frequently due to the absence of an OHCA setting at the time of the emergency call. Volunteers were notified in 1076 cases, with 528 (49.1\%) victims actually needing resuscitation. Annual notifications per volunteer amounted to a mean of $1.30,0.65$ concerning actual resuscitations. The highest increase in survival due to the system (from 16.0 to $34.8 \%$ ) occurred if volunteer density exceeded $0.75 \%$, underscoring its current and future impact if the number of volunteers further increases. Citizen rescuers frequently had no real-life CPR experience nor a medical background, suggesting a sound opportunity to improve the system if more healthcare professionals would apply.

\section{Incidence rates}

We assessed the incidence rate of OHCA based on our prospective registry with a day-to-day assessment of cases as recorded by the ambulance personnel. This method is more accurate than a retrospective death-certificate-based methodology, which leads to an overestimation of OHCA rates. ${ }^{4}$ In agreement with Utstein recommendations ${ }^{3}$ and due to the difficulty in differentiating between OHCA of cardiac and non-cardiac origin in many registries ${ }^{5}$, we included both (presumed) cardiac and non-cardiac causes. As a result of meticulous evaluation of the records from the paramedics and the hospitals, we were able to identify the cause of OHCA in many instances. ${ }^{6}$ To assess incidence more accurately we included, in contrast to many studies ${ }^{7}$, OHCA victims who were found dead unexpectedly and in whom resuscitation had not been attempted. Similar incidence rates were reported from another region in the Netherlands. ${ }^{8}$ A study from the Amsterdam region ${ }^{9}$ showed an incidence rate of 60 per 100,000 inhabitants compared to the crude incidence rate of 69 per 100,000 inhabitants found in our study. The larger number of younger inhabitants in the Amsterdam population might be an explanation for this difference. A previous study performed in the Maastricht area in the 1990 s reported ${ }^{10}$ a crude incidence rate of 100 per 100,000 inhabitants. This higher estimate is due to the inclusion of prolonged deaths reported by the general practitioners. In all age groups, the incidence rate in men was higher than that in women, in agreement with previous studies ${ }^{4,-13}$ where OHCA rates in men were 2-3 times higher. Incidence peaked in the age group 70-79 years.

\section{Resuscitations}

The system was developed to improve survival following cardiac arrest. The majority (88.4\%) of the OHCAs for which the system was activated had a cardiac cause. The dispatch centre did not activate the system in $51.3 \%$ of OHCAs. The most frequent reason was the absence of a resuscitation setting at the time of the emergency call, or the fact that (semi) medical help 
was already at the location or close by. Being a zip-code-based system, no notification could be performed if the zip code was unavailable (15.4\%). Currently, in addition to the zip-code system a GPS-based system is being introduced, making it possible to notify possible rescuers independent of their zip code. Because no zip code is required this novel development will likely lead to an increase of correct notifications, as it will be possible for the dispatcher to notify volunteers for whom no zip-code information is available when a cardiac arrest is clearly recognised.

\section{Notifications}

Volunteers are notified once per year on average, indicating a low burden for the volunteer. In $50.9 \%$ volunteers were notified when no OHCA was present. This may imply that there is room for improvement as regards communication between the witness and the dispatcher as well as in the assessment of potential OHCAs by dispatchers.

\section{Volunteer density and survival}

We observed a positive correlation between the density of citizen rescuers and percentage of survival to hospital discharge. These findings suggest that survival may even further increase with higher numbers of volunteers. This is in line with the recently formulated criteria by the Dutch Heart Foundation (Hartstichting) for so-called 6-minute zones. In order to provide adequate help within 6 minutes an active notification system should be maintained with a high density of volunteers and AEDs. During the study period the number of volunteers in the study region increased from 9000 to 11,000 .

\section{Limitations}

This study was performed in just one area in the Netherlands, questioning the generalisability of our findings. Recent data ${ }^{14}$ from the Dutch Heart Foundation suggest comparable incidence rates in other parts of the country but survival rates differing between 13 and $27 \%$ with a mean of $23 \%$. Although ambulance services act according to similar legislation and treatment protocols and volunteers are trained according to national guidelines, suggesting equal BLS/ AED skills all over the country, these regional differences in survival rates could be due to differences in volunteer densities and/or a variety of other factors. It is very difficult, however, to assess retrospectively which variables might be responsible.

In addition to the TM notification system a GPS-based notification system was introduced and at the time of writing the number of citizen rescuers nationwide has increased substantially. These considerations stress the need for a continuing registration of the number of volunteers and system activations in relation to effectiveness, allowing rational adjustments of the further implementation of the zip-code and GPS-based systems. 


\section{Conclusions}

The system covers about half of the OHCAs needing resuscitation; approximately half of the notifications was an actual resuscitation. The average number of notifications is 1.30 per year per volunteer. The burden for citizen rescuers can be reduced because notification still carries a $50 \%$ chance of resuscitation not being required. The higher increase in survival to hospital discharge in areas with a higher volunteer density suggests that the effectiveness of the system could be further improved if more volunteers per 1000 habitants were to become involved. These findings are important for further implementation of this citizen rescuer system within the community.

\section{Acknowledgements}

We are greatly indebted to the Province of Limburg and the Mercurius Foundation for their financial support of this study; the staff at all the participating hospitals, other institutions and medical students for helping in collecting the data: Zuyderland Hospital Sittard/Heerlen (D. van Kraaij, H. Kragten and the R\&D Cardiology), Laurentius Hospital Roermond (C. Werter and M. Janssen), Sint Jans Gasthuis Weert (H. Klomps), Viecuri Venlo, the emergency medical services of the Municipal Health Service (GGD) South Limburg (N. Otten), AmbulanceZorg Limburg North (L. Triepels), Hartslagnu and Ocean (T. Schrijnemaekers), police department district Limburg South, AED solutions (R. Henderikx), BHV-competent (J. Hoofs), Vivon (M. van Gorp ${ }^{\dagger}$ ) and, last but not least, all volunteers helping to increase the survival rate of their fellow citizens with OHCA are gratefully acknowledged.

\section{Funding}

This work was supported by the Province of Limburg [SAS-202-01794] and the Mercurius Foundation, Heerlen [30957210N].

\section{Conflict of interest}

R.W.M. Pijls, P.J. Nelemans, B.M. Rahel and A.P.M. Gorgels declare that they have no competing interests. 


\section{References}

1. Pijls RW, Nelemans PJ, Rahel BM and Gorgels AP. A text message alert system for trained volunteers improves out-of-hospital cardiac arrest survival. Resuscitation. 2016;105:182-7.

2. Pijls RW, Nelemans PJ, Rahel BM and Gorgels AP. Factors modifying performance of a novel citizen text message alert system in improving survival of out-of-hospital cardiac arrest. Eur Heart J Acute Cardiovasc Care. 2017:2048872617694675.

3. Perkins GD, Jacobs IG, Nadkarni VM, et al. Cardiac arrest and cardiopulmonary resuscitation outcome reports: update of the Utstein Resuscitation Registry Templates for Out-of-Hospital Cardiac Arrest: a statement for healthcare professionals from a task force of the International Liaison Committee on Resuscitation (American Heart Association, European Resuscitation Council, Australian and New Zealand Council on Resuscitation, Heart and Stroke Foundation of Canada, InterAmerican Heart Foundation, Resuscitation Council of Southern Africa, Resuscitation Council of Asia); and the American Heart Association Emergency Cardiovascular Care Committee and the Council on Cardiopulmonary, Critical Care, Perioperative and Resuscitation. Circulation. 2015;132:1286-300.

4. Chugh SS, Reinier K, Teodorescu C, et al. Epidemiology of sudden cardiac death: clinical and research implications. Prog Cardiovasc Dis. 2008;51:213-28.

5. Kong MH, Fonarow GC, Peterson ED, et al. Systematic review of the incidence of sudden cardiac death in the United States. J Am Coll Cardiol. 2011;57:794-801.

6. Pijls RWM, Nelemans PJ, Rahel BM and Gorgels APM. Circumstances and causes of sudden circulatory arrests in the Dutch province of Limburg and the involvement of citizen rescuers. Neth Heart J. 2018;26:41-48.

7. Berdowski J, Berg RA, Tijssen JG and Koster RW. Global incidences of out-of-hospital cardiac arrest and survival rates: Systematic review of 67 prospective studies. Resuscitation. 2010;81:1479-87.

8. Straus SM, Bleumink GS, Dieleman JP, van der Lei J, Stricker BH and Sturkenboom MC. The incidence of sudden cardiac death in the general population. J Clin Epidemiol. 2004;57:98-102.

9. Waalewijn RA, de Vos R and Koster RW. Out-of-hospital cardiac arrests in Amsterdam and its surrounding areas: results from the Amsterdam resuscitation study (ARREST) in 'Utstein' style. Resuscitation. 1998;38:157-67.

10. de Vreede-Swagemakers JJ, Gorgels AP, Dubois-Arbouw WI, et al. Out-of-hospital cardiac arrest in the 1990's: a population-based study in the Maastricht area on incidence, characteristics and survival. J Am Coll Cardiol. 1997;30:1500-5.

11. Kannel WB and Schatzkin A. Sudden death: lessons from subsets in population studies. J Am Coll Cardiol. 1985;5:141B-149B.

12. Kim C, Fahrenbruch CE, Cobb LA and Eisenberg MS. Out-of-hospital cardiac arrest in men and women. Circulation. 2001;104:2699-703.

13. Deo $R$ and Albert CM. Epidemiology and genetics of sudden cardiac death. Circulation. 2012;125:620-37.

14. Zijlstra JA, Radstok A, Pijls R, et al. Overleving na een reanimatie buiten het ziekenhuis: vergelijking van de resultaten van 6 verschillende Nederlandse regios Reanimatie in Nederland, 2016 Den Haag Nederlandse Hartstichting 2016. 
Chapter 6

General discussion 


\section{Magnitude of the problem}

\section{Incidence of out-of-hospital circulatory arrest, resuscitation incidence and survival}

To get an impression about the relevance of starting and maintaining a community responder system it is important to assess the overall incidence of sudden out-of-hospital circulatory arrest (OHCA) in the study region, the representativeness for other parts of the Netherlands and the incidence of resuscitations where the community responder system might be involved. According to our data the estimated incidence of OHCA in the study region (the province of Limburg) is 69 per 100,000 inhabitants per year. This figure is lower compared to a previous study ${ }^{1}$ in the Maastricht area in the 1990's, where a crude incidence rate of 100 per 100,000 inhabitants per year was reported, similar to incidence rates retrieved from the Integrated Primary Care Information (IPCI) project with data from computer-based patient records of a group of 150 general pratitioners (GPs) in the Netherlands. ${ }^{2}$ This higher incidence could be due to inclusion of prolonged deaths reported by the emergency medical service (EMS) or by GPs. An alternative explanation is that there has been a real decline due to a healthier life style over the last decades, better treatment of coronary disease and the widespread introduction of implantable cardioverter-defibrillators (ICD). ${ }^{3}$

Not all OHCA victims are resuscitated and according to the Dutch Heart Foundation the resuscitation incidence of OHCA with cardiac cause in the Netherlands is 31 to 40 per 100,000 inhabitants per year. ${ }^{4}$ When both cardiac and non-cardiac causes are taken into account the resuscitation incidence is around 48 per 100,000 inhabitants per year ${ }^{4}$ which is comparable with the estimate of the resuscitation incidence of 45 per 100.000 inhabitants per year in our study. This finding implies that 24 cases per 100,000 inhabitants per year (OHCA incidence of 69 minus resuscitation incidence of 45 ) or 269 cases per year are not resuscitated in the province of Limburg mainly because they were found dead or had a do not resuscitate policy. Survival after cardiac arrest where resuscitation efforts were attempted has been shown to vary considerably which is to a major extent caused by patient selection, various factors at the arrest, the resuscitative efforts performed and perhaps differences between the populations studied. ${ }^{5}$ The overall survival of the OHCA victims with cardiac etiology resuscitated in our study ( $n=833$ ) was $27.9 \%$ (unpublished data). In the subgroup of OHCAs where the volunteer system was activated the survival to hospital discharge was $16 \%$ if no volunteer attended, whereas survival increased up to $27 \%$ if at least one volunteer attended the resuscitation. More in detail, we found that in witnessed cases survival was only $9 \%$ if cardiopulmonary resuscitation (CPR) was not started by the witness(es) and no community responder attended but increased to $46 \%$ if both the witness started CPR and at least one volunteer attended (unpublished data). This underscores the importance of the community responder system as well as CPR skills within the community to improve survival after OHCA. 


\section{Contribution of the community responder system to survival}

\section{Window of opportunity}

This thesis shows that survival can almost double when an OHCA victim is attended by one or more volunteers. Largest gain of survival is obtained with ambulance arrival times between 6 and 11 minutes, which can be seen as the window of opportunity for the notified community responders. Within this window their efforts have maximal effect on survival, whereas this benefit decreases at later arrival times of the ambulance because professional support by ambulance personnel comes (too) late. The crucial time interval of maximum 7 minutes between collapse and start of professional BLS in which there is still favorable outcome of OHCA is referred to as the bystander's window. ${ }^{6}$ One could state that the community responders shortly fulfill the professional role during this window of opportunity.

\section{OHCA during the day versus evening/night}

The contribution of the community responder system to survival at hospital discharge is higher during evening and night than during day time. In case no volunteer attended and survival depends solely on the functioning of standard care, survival decreased substantially after OHCA occurring in the evening or night (from $21.0 \%$ at day time to $11.6 \%$ in the evening or night), whereas survival slightly increased when one or more responders did attend (from $25.9 \%$ at day to $28.7 \%$ during evening or night). The most likely explanation is that community responders compensated for longer delay times of the ambulance during evening and night. This possibility is supported by our data showing that during evening/night the ambulance arrival time $>11$ min was $34.5 \%$ in contrast to $20.6 \%$ during the day $(P<0.001)$. During the evening/night the system could therefore more effectively compensate for the longer delay time of the ambulance.

\section{Contribution to resuscitation setting and outcomes}

Our findings also suggest that the community responder system substantially attributed to early CPR and early defribillation which are two important links in the chain of survival. ${ }^{7}$ In $24.7 \%$ of the 291 cases where community responders did arrive on the scene, they were the first to start basic life support (BLS), in $26.8 \%$ they were the first to connect an automated external defibrillator (AED) and in 59.9\% the initial rhythm recorded was shockable. As a result, when notified community responders attend a resuscitation, OHCA victims have a higher probability to arrive at the hospital alive compared to OHCA victims where no responders attend, $56.7 \%$ (165/291) vs 51.1\% (67/131). Additionally, of the patients who arrive alive at the hospital relatively more patients survive at hospital discharge if at least one volunteer responded compared to no responders (47.9\% vs $31.3 \%)$, suggesting a better medical condition at hospital arrival. A substudy (unpublished and not yet reported in this thesis, performed by Eva Claassens and Renee Roose as part of their school research project guided by Jan Claassens, MScT) evaluated 67 patients with OHCA who were admitted to the 
emergency department (ED) of the Maastricht University Medical Centre . In 71\% of the 47 patients where community responders attended, a perfusing rhythm was found versus $55 \%$ in the 20 patients without responders. Spontaneous circulation returned in $65 \%$ vs $55 \%$ and the proportion of patients who died at the ED was $25 \%$ vs $40 \%$.

\section{Witness versus bystander}

In contrast to most studies, a prespecified distinction was made between settings where a witness or a bystander started CPR. We defined a witness as someone who saw, heard or monitored the arrest whereas a bystander was defined as a person who did not witness the event but arrived at the scene after the arrest. We found a marked contribution of a witness to survival. The odds of survival was about three times higher when BLS was started by the witness compared to settings where BLS was started by EMS (adjusted odds ratio $(O R)=2.96)$. Start of BLS by a bystander or first responder (police- and firemen) had no significant effect on survival compared to BLS started by EMS (adjusted OR=1.14). This finding emphasizes the need of wide spread CPR skills among the community. Other (unpublished) observations underscore the importance of witness initiated resuscitation and the support by the community responders: in case neither witness nor notified rescuer were active survival was only $8.9 \%$, in contrast to $45.6 \%$ if both indeed participated.

\section{Quality of survival}

Patients discharged alive from the hospitals were sent home in $92 \%$. Furthermore, in a subgroup of 34 of the 100 survivors that were discharged, 28 patients (82.4\%) had no significant to slight disability based on Modified Rankin Scale scores. This low degree of disability is in agreement with studies by Moulaert et al. in the same geographical area; high quality of life was experienced by $80 \%$ of the survivors and $70 \%$ of employed patients returned to work within 12 months after discharge..$^{89}$ Outcome could be further improved by focused rehabilitation; an intervention focused on detecting and managing the effects of the cardiac arrest on both emotional and cognitive level. ${ }^{9}$

\section{The system from the perspective of volunteers}

This thesis also explored the burden for community responders and it was estimated that community responders are notified at a mean rate of 1.3 times a year. Notification was justified in about half of the cases, whereas in the other half no actual OHCA was present. Patients were already deceased or resuscitation was not needed due to reasons such as spontaneous recovery after collapsing. This finding might indicate need for improvement of recognition of resuscitation settings by the dispatcher and improved communication of the witness to the dispatcher. The latter can be realised by creating more awareness within the population about indicators of OHCA and how to report this in the emergency call. 
The volunteer system was not developed for cases of non-cardiac cause of circulatory arrests and although compliance with standardised EMS protocol(s) increases recognition ${ }^{10}$ about $17 \%$ of the attended cases remained of non-cardiac cause. Citizens should be made aware that clearly describing the emergency situation will help the dispatcher to evaluate the situation correctly. Nevertheless, if volunteers are notified in non-cardiac causes they still can play an important role in the initial treatment of the event: a frequent cause is asphyxia due to suffocation, a situation where a maneuver putting sudden high abdominal pressure (the Heimlich maneuver) can be effectively applied.

\section{Coverage by the rescuer system}

During the study period the community responder system covered about half of the OHCAs, of which the majority (88\%) had a cardiac cause. Most common reasons for not activating the system were a resuscitation setting not being yet present at the time of notification at the dispatch centre or help already being on the way or on location. Such situations represent non-modifiable factors in contrast to modifiable factors such as the absence of the zip code of the resuscitation location, occurring in $15.4 \%$ of cases. Being dependent on the zip codes makes the system quite static. Therefore the currently concomitantly applied global positioning system (GPS)-based system allows to notify rescuers independently from their zip code.

\section{Opportunities for improvement}

\section{Volunteer density}

A relation was observed between volunteer density and survival gain due to the system. If the density exceeded $0.75 \%$, survival increased to $34.8 \%$ compared to $20.6 \%$ at a density below $0.25 \%$. This suggests that a further increase in number of volunteers might lead to even higher survival rates.

\section{Public awareness and CPR training}

An important aspect still being underdeveloped is the public awareness about OHCA and mass CPR training of citizens. There are numerous ways to increase both the public awareness and number of citizens that are able to perform CPR. Of help are global initiatives suchs as a the "restart a heart day" (https://www.erc.edu/about/restart) and the sudden cardiac awareness month in October (https://www.hrsonline.org/News/Sudden-Cardiac-Arrest-SCA-Awareness) and many countries have used media campaigns to create awareness. Involvement of the government can also help to increase public awareness and number of citizens that are able to perfom CPR. For example, some countries require that persons who apply for a driver's 
licence first follow a CPR training course. Also in many countries training CPR at elementary or secondary school is mandatory. ${ }^{11-19}$

\section{Future developments}

\section{Chain of survival}

The chain of survival, including four links, plays a crucial role to increase survival after OHCA. ${ }^{7}$ These four links are: 1) early recognition of (impending) cardiac arrest and notification, 2) early chest compressions and ventilation by the witness, 3) early defibrillation and 4) early post resuscitation care. Figure 1 depicts this concept.
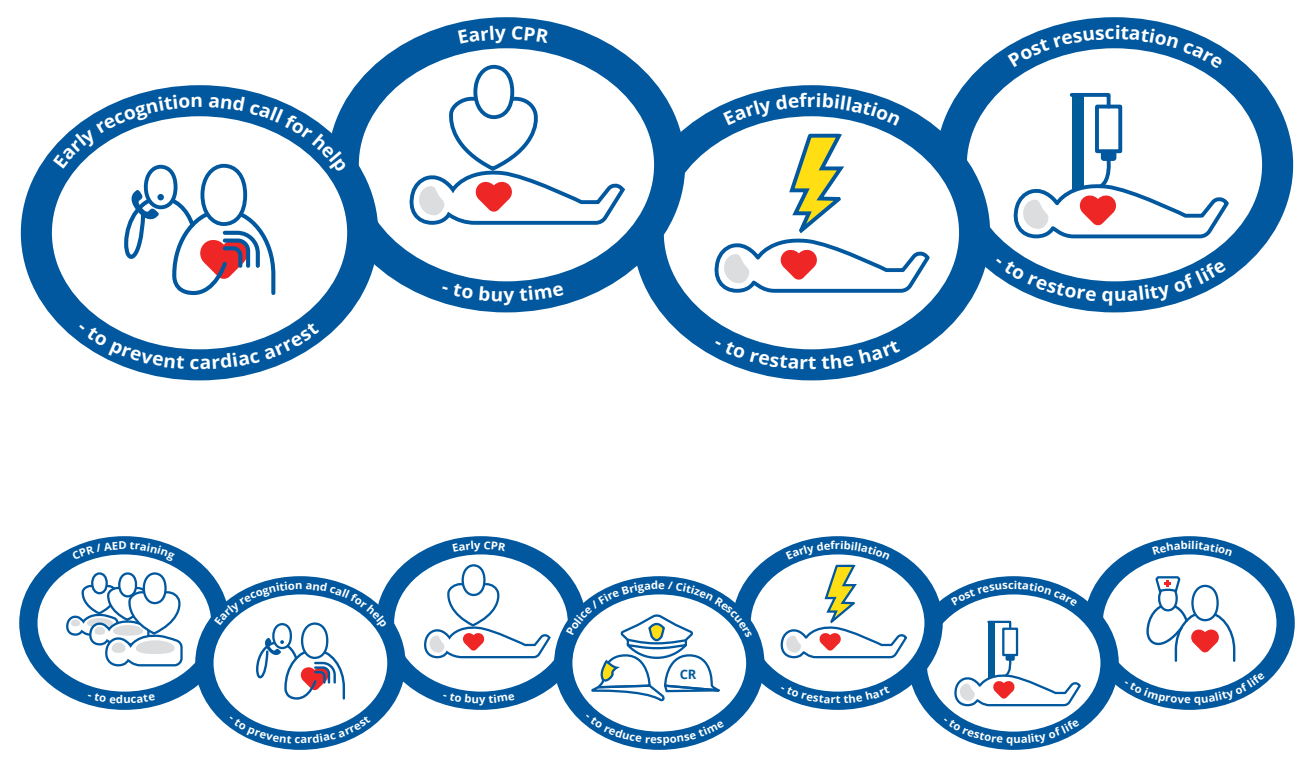

Fig. 1. Chain of survival and chain of survival with additive links.

The studies in this thesis indicate the crucial role of citizens (both witness and community responders) in the improvement of survival of OHCA with cardiac cause, next to police officers and firefighters as first responders and a well-organised and continuously available emergency medical system. Recruitment/enhancement of these first responders (police, fire brigade and community responders) could be considered as an extra link, as depicted in figure 1. 


\section{Resuscitation skills of the public}

The need for citizen rescuers was recognised by the Dutch Heart Foundation (Hartstichting) by encouraging citizens to establish zones in residential areas where within 6 minutes basic life support and the deployment of an AED will be provided, coined as "6-minute zones". However, according to our experience in about half of the resuscitation settings no witness started BLS and in one third no citizen rescuer responded to the notification. These findings reveal an urgent need for more resuscitation skills within the community and more willingness to apply as a community responder. As mentioned above the former can be achieved by introducing resuscitation training in school, preferably in secondary schools. In Belgium, Denmark, France, Italy and Portugal there is legislation for mandatory CPR training in school. ${ }^{19}$ In contrast ${ }^{17,20-23}$ in the Netherlands no legislating or regulating activities exist from the central government. Programs depend on local or individual initiatives, such as the Taskforce QRS (Qualitative Resuscitation by Students), consisting of medical students who as volunteers provide resuscitation training in secondary schools. Untill recently, in the Netherlands only physicians, nurses and resuscitation training officers were allowed to provide CPR training. Therefore it was studied by our group whether medical students can provide CPR training for secondary school students as well as registered nurses. ${ }^{24}$ This study confirmed that medical students are equally capable of teaching BLS/AED to secondary school pupils as registered nurses. These medical students can redeem the need for more CPR instructors and instructor trainers.

Next to school pupils adults should be more encouraged and facilitated to take a CPR training course and to apply to the community responder system.

The millions of health care professionals and other citizens with professionally acquired resuscitation skills, such as company emergency officers, are an important but insufficiently tapped source to be recruited as notifiable community responders, although an encouraging $25 \%$ of community responders was found in our study to be health care professionals.

\section{Number of AEDs}

Within the community responder system as it exists in the Netherlands there is a need for more registered AEDs. A large contingent of AEDs is potentially available, considering the many AEDs already being present in public buildings, restaurants, shops and offices of GPs for example. These AEDs could be exteriorised and made available for the network.

\section{Technical improvement of AEDs}

Technical improvement of AEDs is needed, such as incorporating feedback systems to guide rescuers, GPS systems for better localisation of the resuscitation site, accurate clock times for better monitoring the timeline of the resuscitation process and electronic transmission of the recording to the medical facility to where the patient is transferred. 


\section{The role of the GP}

GPs could also play an essential role in the further development of the community responder system. Most GPs are equipped with an AED which could be placed outside and made available for the system. GPs could actively promote resuscitation training and registration into the system. They could also register themselves as a community responder, along with other professionals from their practice. Furthermore, GPs can play an important role in the follow-up care for OHCA with cardiac cause survivors and their partners and other family members and for community responders that were involved in a resuscitation attempt with potentially heavy emotional impact.

\section{GPS based system}

In our study the availability of community responders was dependent on zip codes both of the community responder and the victim. Although this system already was found to be effective it is restricted by the need for knowing the zip code of the resuscitation setting and by the presence of the community responder and his indicated zip code. These restrictions will be solved by the newly introduced GPS-based system where community responders close to the victim can be identified independent from their zip code. Further studies are needed to evaluate this new approach (next to the still continuing zip code based system), which emphasizes the need for continuous and high quality registries to monitor details of the resuscitation scenarios and outcomes in OHCA.

\section{Rehabilitation}

More attention should be paid to rehabilitation after survived cardiac arrest, not only to the patients but als to their caregivers. ${ }^{25}$ Focused rehabilitation programs have shown to improve the quality of the recovery. Studies in our study region have confirmed the value of support by qualified nurses for this purpose. ${ }^{9}$

\section{Unwitnessed victims}

One of the major determinants of survival after OHCA is the event being witnessed. Unfortunately, in 30\% of all registered OHCAs the patient was found dead and $22 \%$ of the resuscitation attempts were unwitnessed. Hopefully within the next future a mode of automated ventricular fibrillation detection and notification, by for example smartwatches, will be developed which not only will allow identification of unwitnessed victims but will also shorten the notification and dispatching time. ${ }^{26}$

\section{Evolution to a Q-chain of survival}

In conclusion, to achieve high quality outcome of OHCA victims we suggest adding links to the chain of survival according to recent developments, such as 1) increase of CPR training preferably in school, 2) further implementation of the community responder system and 3) focused rehabilitation (see figure 1). 
Addition of CPR training as first link (preferably at an early age such as secondary school pupils), allows better performance in the next links. Recruitment/enhancement of first responders as an extra fourth link would help to decrease the time between onset of the OHCA and start of BLS with AED use. The last and seventh link puts focus on rehabilitation of the OHCA survivors and their caregivers.

All aspects of the survival chain should be continuously monitored in a registry to allow adequate adjustments for improvement.

\section{Automated data registry}

During the studies, several sources for data collection were used; 1) the dispatch centres from Limburg North and South, 2) their respective emergency medical services, 3) notified volunteers, 4) the database of community responder system organisation, 5) six hospitals in Limburg and 6) AED providers. The data of all these sources were combined to get insight in the OHCA setting and survival. Combining data from all sources is labour intensive and it is challenging to obtain accurate information about the actual resuscition scenario because of the rapidly changing nature of a resuscitation setting. Systems should be programmed in such a way that data are automatically collected and sent to a server/registry. A registry can be of great value for future research of the respective links and their interrelation. 


\section{References}

1. de Vreede-Swagemakers JJ, Gorgels AP, Dubois-Arbouw WI, et al. Out-of-hospital cardiac arrest in the 1990's: a population-based study in the Maastricht area on incidence, characteristics and survival. J Am Coll Cardiol. 1997;30:1500-5.

2. Straus SM, Bleumink GS, Dieleman JP, van der Lei J, Stricker BH and Sturkenboom MC. The incidence of sudden cardiac death in the general population. J Clin Epidemiol. 2004;57:98-102.

3. Hulleman M, Berdowski J, de Groot JR, et al. Implantable cardioverter-defibrillators have reduced the incidence of resuscitation for out-of-hospital cardiac arrest caused by lethal arrhythmias. Circulation. 2012;126:815-21.

4. Hulleman M, Nas J, Pijls R, et al. Afname van de proportie schokbare beginritmes bij reanimaties buiten het ziekenhuis in Nederland Reanimatie in Nederland, 2016 Den Haag: Nederlandse Hartstichting 2016.

5. Engdahl J, Holmberg M, Karlson BW, Luepker R and Herlitz J. The epidemiology of out-of-hospital 'sudden' cardiac arrest. Resuscitation. 2002;52:235-45.

6. Breckwoldt J, Schloesser S and Arntz HR. Perceptions of collapse and assessment of cardiac arrest by bystanders of out-of-hospital cardiac arrest (OOHCA). Resuscitation. 2009;80:1108-13.

7. Nolan J and European Resuscitation C. European Resuscitation Council guidelines for resuscitation 2005. Section 1. Introduction. Resuscitation. 2005;67 Suppl 1:S3-6.

8. Moulaert VR, Goossens M, Heijnders IL, Verbunt JA and Heugten CM. Early neurologically focused follow-up after cardiac arrest is cost-effective: A trial-based economic evaluation. Resuscitation. 2016;106:30-6.

9. Moulaert VR, van Heugten CM, Winkens B, et al. Early neurologically-focused follow-up after cardiac arrest improves quality of life at one year: A randomised controlled trial. Int J Cardiol. 2015;193:8-16.

10. Berdowski J, Beekhuis F, Zwinderman AH, Tijssen JG and Koster RW. Importance of the first link: description and recognition of an out-of-hospital cardiac arrest in an emergency call. Circulation. 2009;119:2096-102.

11. Malta Hansen C, Zinckernagel L, Ersboll AK, et al. Cardiopulmonary Resuscitation Training in Schools Following 8 Years of Mandating Legislation in Denmark: A Nationwide Survey. J Am Heart Assoc. 2017;6.

12. Reder $\mathbf{S}$ and Quan L. Cardiopulmonary resuscitation training in Washington state public high schools. Resuscitation. 2003;56:283-8.

13. Miro O, Jimenez-Fabrega X, Espigol G, et al. Teaching basic life support to 12-16 year olds in Barcelona schools: views of head teachers. Resuscitation. 2006;70:107-16.

14. Lafferty C, Larsen PD and Galletly D. Resuscitation teaching in New Zealand schools. N Z Med J. 2003;116:U582.

15. Perkins GD, Lockey AS, de Belder MA, et al. National initiatives to improve outcomes from out-ofhospital cardiac arrest in England. Emerg Med J. 2016;33:448-51. 
16. Bottiger BW, Semeraro F and Wingen S. "Kids Save Lives": Educating Schoolchildren in Cardiopulmonary Resuscitation Is a Civic Duty That Needs Support for Implementation. J Am Heart Assoc. 2017;6.

17. Cave DM, Aufderheide TP, Beeson J, et al. Importance and implementation of training in cardiopulmonary resuscitation and automated external defibrillation in schools: a science advisory from the American Heart Association. Circulation. 2011;123:691-706.

18. Bottiger BW, Semeraro F, Altemeyer KH, et al. KIDS SAVE LIVES: School children education in resuscitation for Europe and the world. Eur J Anaesthesiol. 2017;34:792-796.

19. Semeraro F, Wingen S, Schroeder DC, et al. KIDS SAVE LIVES-Three years of implementation in Europe. Resuscitation. 2018;131:e9-e11.

20. Wissenberg M, Lippert FK, Folke F, et al. Association of national initiatives to improve cardiac arrest management with rates of bystander intervention and patient survival after out-of-hospital cardiac arrest. JAMA. 2013;310:1377-84.

21. Plant N and Taylor K. How best to teach CPR to schoolchildren: a systematic review. Resuscitation. 2013;84:415-21.

22. Lukas RP, Van Aken H, Molhoff T, et al. Kids save lives: a six-year longitudinal study of schoolchildren learning cardiopulmonary resuscitation: Who should do the teaching and will the effects last? Resuscitation. 2016;101:35-40.

23. Bohn A, Van Aken HK, Mollhoff T, et al. Teaching resuscitation in schools: annual tuition by trained teachers is effective starting at age 10. A four-year prospective cohort study. Resuscitation. 2012;83:619-25.

24. Cuijpers PJ, Bookelman G, Kicken W, de Vries W and Gorgels AP. Medical students and physical education students as CPR instructors: an appropriate solution to the CPR-instructor shortage in secondary schools? Neth Heart J. 2016;24:456-61.

25. Beesems SG, Wittebrood KM, de Haan RJ and Koster RW. Cognitive function and quality of life after successful resuscitation from cardiac arrest. Resuscitation. 2014;85:1269-74.

26. Wellens HJ, Lindemans FW, Houben RP, et al. Improving survival after out-of-hospital cardiac arrest requires new tools. Eur Heart J. 2016;37:1499-503. 


\section{Chapter 7}

Samenvatting

Summary

Valorisation

Dankwoord

About the author

List of publications 


\section{Samenvatting}

Het doel van het proefschrift is om te bepalen of een burgerhulpsysteem bijdraagt aan een hogere overleving na een (cardiale) hartstilstand buiten het ziekenhuis. Het burgerhulpsysteem bestaat uit burgers die worden opgeroepen om een slachtoffer van een hartstilstand te reanimeren. We hebben ook onderzocht welke factoren bijdragen aan het prestatievermogen van het systeem, wat de onderliggende oorzaken (zowel cardiaal als niet cardiaal) van de hartstilstanden buiten het ziekenhuis zijn en wat de kenmerken van het burgerhulpsysteem zijn. Over een periode van 2 jaar werden alle gegevens met betrekking tot reanimaties buiten het ziekenhuis in de provincie Limburg verzameld.

In hoofdstuk 2 werd de effectiviteit van het burgerhulpsysteem bepaald door twee groepen met elkaar te vergelijken. In één groep werd het burgerhulpsysteem geactiveerd maar kwam geen enkele vrijwilliger bij de reanimatie opdagen $(n=131)$. In deze groep werd dus de standaard zorg voor een reanimatie buiten het ziekenhuis geleverd. In de andere groep werd het burgerhulpsysteem geactiveerd en kwam er minimaal één vrijwilliger bij de reanimatie opdagen ( $n=291$ ). In deze groep werd er dus naast de standaard zorg extra hulp geboden door de vrijwilliger(s). Het bleek dat de overleving (tot ontslag uit het ziekenhuis) in de eerste groep 16 procent was en in de tweede groep 27 procent $(P=.013)$. Dit komt overeen met een odds ratio (OR) van 1.95 (95\% Cl 1.15-3.33; $P=.014)$. Na correctie voor mogelijk verstorende factoren nam de odds ratio toe $(\mathrm{OR}=2.82 ; 95 \% \mathrm{Cl} 1.52-5.24 ; P=.001)$. Van de 100 overlevers werd $92 \%$ naar huis ontslagen zonder of met beperkte neurologische gevolgen.

De hogere overlevingskans in de aanwezigheid van vrijwilligers suggereert dat het systeem de tijd van het ontstaan van de hartstilstand tot start van de reanimatiepoging verkort. Dit wordt ondersteund door de bevinding dat een schokbaar ritme vaker aanwezig was als er vrijwilligers kwamen opdagen (59.9\% versus 46.5\%, $P=.015$ ). Deze bevinding kan samenhangen met de kortere tijdsduur tot start van de reanimatie maar ook aan de goede kwaliteit van de reanimatiehandelingen van de vrijwilligers. Het burgerhulpsysteem blijkt dus effectief te zijn in het verhogen van de overlevingskans na een plotselinge hartstilstand buiten het ziekenhuis op basis van een cardiale oorzaak en in de meeste gevallen met een goede neurologische uitkomst.

De kans op overleving wordt steeds kleiner als het tijdsinterval tussen het optreden van de hartstilstand en begin van de reanimatie groter wordt. De ambulancedienst arriveert vaak (72.8\%) na 6 minuten. Het doel van het burgerhulpsysteem is dan ook om ervoor te zorgen dat zo snel mogelijk adequate hulp (vrijwilligers) bij het slachtoffer ter plaatse is zodat de reanimatie al kan worden gestart voordat de ambulance arriveert. Het systeem is dus waarschijnlijk het meest effectief als het wordt ingezet in situaties waarbij er een vertraging aanwezig is tussen de aanvang van de harstilstand en het starten van het reanimeren. Factoren die vertragend zouden kunnen werken zijn de locatie van het slachtoffer (thuis versus publieke locatie), het 
dagdeel waarin de hartstilstand optreedt (overdag versus avond/nacht) en aanrijdtijden van de ambulance. Daarnaast zal het reduceren van de tijd tussen aanvang van de harstilstand en het starten met reanimeren door de inzet van vrijwilligers waarschijnlijk meer effect hebben bij hartstilstanden waarbij een getuige aanwezig was. Hartstilstanden waarbij geen getuige aanwezig is hebben al bij voorbaat een slechte prognose. In hoofdstuk $\mathbf{3}$ hebben we de invloed van deze vier factoren op het prestatievermogen van het systeem onderzocht. Uit het onderzoek kwam naar voren dat de effect van het systeem het hoogst is in situaties waarbij er een getuige aanwezig was bij de plotselinge hartstilstand $(\mathrm{OR}=2.25 ; 95 \% \mathrm{Cl} 1.27-4.00$; $P=.005)$ vergeleken met de situatie waarbij er geen getuige aanwezig was (OR=0.64; $95 \% \mathrm{Cl}$ $0.10-4.05 ; P=.638)$, waarbij de hartstilstand plaatsvond in de thuissituatie (OR=2.28; $95 \% \mathrm{Cl}$ $1.21-4.28 ; P=.011)$ vergeleken met hartstilstanden buiten de thuissituatie (OR=1.36; 95\% $\mathrm{Cl} 0.47$ - 3.89; $P=.570$ ), waarbij de aankomsttijd van de eerste ambulance 7 tot 10 minuten was $(\mathrm{OR}=2.63 ; 95 \% \mathrm{Cl} 1.09-6.35 ; P=.032)$ vergeleken met een aankomsttijd van $\leq 6$ minuten (OR=1.96; 95\% Cl $0.81-4.73 ; P=.137$ ) of een aankomsttijd van $\geq 11$ minuten (OR=1.29; 95\% $\mathrm{Cl} 0.39-4.31 ; P=.679)$, en in situaties waarbij de reanimatiesetting ontstond in de avond of nacht (OR=3.07; 95\% Cl 1.34-7.03; $P=.008)$ vergeleken met situaties waarbij de reanimatie setting overdag ontstond $(\mathrm{OR}=1.32 ; 95 \% \mathrm{Cl} 0.65-2.67 ; P=.441)$. De $P$-waarden voor de interactietests waren, waarschijnlijk door het beperkt aantal patiënten, niet significant.

Hoofdstuk 4 vormt een inventarisatie van de oorzaken van plotselinge hartstilstanden buiten het ziekenhuis en de omstandigheden waarin de hartstilstanden optraden. Tijdens de onderzoeksperiode zijn 1546 hartstilstanden in de provincie Limburg geregistreerd. Van deze 1546 bleken er 461 een lijkvinding te zijn. Reanimaties die in de ambulance ontstonden $(n=32)$ werden geëxcludeerd evenals reanimaties in besloten publieke locaties met een AED en bedrijfshulpverleners ( $n=85$ ). In totaal werden er 968 reanimaties geïncludeerd waarbij het burgerhulpsysteem bij 492 reanimaties werd geactiveerd en bij 476 reanimaties niet. Als het systeem geactiveerd was kon de oorzaak van de hartstilstand in 345 achterhaald worden en bleek deze in 83.2\% (287/345) cardiaal te zijn. De belangrijkste oorzaak van de cardiale hartstilstanden was acuut en chronisch coronarialijden en in bijna $84 \%$ vond de hartstilstand in de thuissituatie plaats. In $75 \%$ van de hartstilstanden was er een getuige waarbij in $60.9 \%$ van deze gevallen de getuige of omstanders begonnen met reanimeren. In $18 \%$ van de gevallen was de burgerhulpverlener de eerste die begon met reanimeren voordat de ambulance arriveerde. In ongeveer $75 \%$ arriveerde de ambulance na 6 minuten of later. Het bleek dat de meerderheid van de patiënten met een plotselinge hartstilstand geen cardiovasculaire voorgeschiedenis heeft, dat het vaak (83\%) gevallen betreft met een cardiale oorzaak en dat veel hartstilstanden in de thuissituatie plaatsvinden (84\%).

De incidentie van een plotselinge hartstilstand buiten het ziekenhuis met cardiale oorzaak werd onderzocht in hoofdstuk 5. Tevens werden vragen beantwoord als: hoe vaak is het systeem bij plotselinge hartstilstanden geactiveerd en wat waren de redenen om het 
systeem niet te activeren; hoe vaak kan een vrijwilliger per jaar worden opgeroepen; heeft de vrijwilligersdichtheid invloed op de overlevingskans?

De ruwe (ongecorrigeerde) incidentie van een plotselinge hartstilstand buiten het ziekenhuis met een cardiale oorzaak bedraagt 69 per 100,000 inwoners per jaar, 94 per 100,000 mannen per jaar en 44 per 100,000 vrouwen per jaar. De voor leeftijd en geslacht gestandaardiseerde incidentie met behulp van de European Standard Population (ESP) bleek 67 per 100,000 inwoners per jaar, 95 per 100,000 mannen per jaar en 39 per 100,000 vrouwen per jaar. In overeenstemming met andere studies ${ }^{1-6}$ bleek bij alle leeftijdsgroepen de incidentie hoger te zijn voor mannen dan voor vrouwen en piekte de incidentie in de leeftijdsgroep 70 tot en met 79 jaar.

Tijdens de onderzoeksperiode waren er ongeveer 9000 geregistreerde vrijwilligers. Van deze 9000 vrijwilligers was $60 \%$ man, had $59 \%$ geen ervaring met werkelijke reanimaties en was $27.4 \%$ zorgprofessional. In $51.3 \%$ bleek er wel een plotselinge hartstilstand te zijn maar werd het systeem niet geactiveerd. Vaak (47.9\%) was de reden hiervoor dat er tijdens de 112-melding nog geen sprake was van een hartstilstand. De reanimatiesetting ontstond pas op het moment dat de eerste ambulance al aan het rijden was. Het kwam ook voor dat de postcode van de reanimatielocatie niet bekend was (15.4\%) waardoor het systeem niet kon worden geactiveerd of dat er al medische hulp (zoals een arts tijdens een wielerronde) aanwezig was op de locatie (8.8\%). Tijdens de onderzoeksperiode is het systeem 1076 keer geactiveerd waarbij er 548 (51\%) keer geen daadwerkelijke reanimatiesetting aanwezig was. Ook bleek dat vrijwilligers gemiddeld 1 keer per jaar opgeroepen worden. De effectiviteit van het systeem lijkt een relatie te hebben met het procentuele aantal vrijwilligers in een gemeente. In gemeenten met een vrijwilligersdichtheid van $\geq 7.5$ vrijwilligers per 1000 inwoners werd een overlevingskans van $34.8 \%$ gezien indien er vrijwilligers gehoor gaven aan de oproep. De overlevingskans was met $20.6 \%$ lager in gemeenten met een dichtheid van minder dan 2.5 vrijwilligers per 1000 inwoners. 


\section{References}

1. de Vreede-Swagemakers JJ, Gorgels AP, Dubois-Arbouw WI, et al. Out-of-hospital cardiac arrest in the 1990's: a population-based study in the Maastricht area on incidence, characteristics and survival. J Am Coll Cardiol. 1997;30:1500-5.

2. Chugh SS, Reinier K, Teodorescu C, et al. Epidemiology of sudden cardiac death: clinical and research implications. Prog Cardiovasc Dis. 2008;51:213-28.

3. Straus SM, Bleumink GS, Dieleman JP, van der Lei J, Stricker BH and Sturkenboom MC. The incidence of sudden cardiac death in the general population. J Clin Epidemiol. 2004;57:98-102.

4. Waalewijn RA, de Vos R and Koster RW. Out-of-hospital cardiac arrests in Amsterdam and its surrounding areas: results from the Amsterdam resuscitation study (ARREST) in 'Utstein' style. Resuscitation. 1998;38:157-67.

5. Kannel WB and Schatzkin A. Sudden death: lessons from subsets in population studies. J Am Coll Cardiol. 1985;5:141B-149B.

6. Kim C, Fahrenbruch CE, Cobb LA and Eisenberg MS. Out-of-hospital cardiac arrest in men and women. Circulation. 2001;104:2699-703. 


\section{Summary}

Sudden out-of-hospital circulatory arrest (OHCA) is an important public health problem ${ }^{1,2}$ in industrialised countries and mainly caused by cardiac disease. ${ }^{3}$ In order to increase the low survival rates of OHCA a community responder system was developed in which trained volunteers can be notified and send to an OHCA. Although the system is widely implemented in the Netherlands it is not known whether this system has an effect on survival of OHCA. This thesis evaluates the benefit of the system regarding outcomes of the victims, the efficiency and effectiveness of the system, and the potentical burden to the citizen rescuers. The results of the different studies this thesis comprises are described and summarised below.

\section{Chapter 2 Does the text message alert system for trained volunteers improve out-of-hospital cardiac arrest survival?}

Whether the community responder system (alert system) improves survival at hospital discharge in victims of OHCA due to a cardiac cause is reported in this chapter. On site resuscitation attempts for presumed cardiac arrest were made in 833 cases who were still alive at the moment of arrival of one or more volunteers or the ambulance. The alert system was activated in 422 cases. The study population consisted of these 422 cases. Two cardiopulmonary resuscitation (CPR) scenarios were compared: 1 . alert system was activated but no responders attended $(n=131)$, and 2 . alert system was activated with attendance of 1 or more responder(s) ( $n=291$ ). Scenario 1 (with no responders attending) is an unwanted situation, but for the purpose of our study these cases were considered as the reference group because survival of the OHCA victims depended on standard care.

The primary outcome measure was the proportion of OHCA victims who survived to hospital discharge. Secondary outcome measures were proportion with return of spontaneous circulation (ROSC) at departure from site of the OHCA and at hospital arrival, proportion with discharge to rehabilitation centre and nursing / caring home and Modified Rankin ${ }^{4}$ score (mRS); a score which is used to determine the degree of disability at hospital discharge.

Survival to hospital discharge was $16.0 \%$ in scenario 1 (no responders) and $27.1 \%$ in scenario 2 (one or more responders) corresponding with odds ratio $(\mathrm{OR})=1.95$ (95\% Cl 1.15-3.33; $P=.014)$. After adjustment for potential confounders the $\mathrm{OR}$ increased $(\mathrm{OR}=2.82 ; 95 \% \mathrm{Cl}$ $1.52-5.24 ; P=.001$ ). Of the 100 survivors, $92 \%$ were discharged from the hospital to their home with no or limited neurological sequelae.

The higher survival rate in scenario 2 compared to scenario 1 suggests that the system successfully can decrease the time between onset of the OHCA and start of resuscitation. Importantly, a shockable initial rhythm was recorded more often in scenario 2 compared to scenario 1 (59.9\% vs $46.5 \%, P=.015)$. This finding could be related to a decrease in time to start resuscitation, but also to high quality basic life support (BLS) efforts of these certified volunteers. It is concluded that the alert system is effective in increasing survival to hospital 
discharge after a sudden cardiac arrest and that the degree of disability or dependence after survival is low.

\section{Chapter 3 Factors modifying performance of the citizen text message alert system in improving survival of out-of-hospital cardiac arrest}

The aim of this study was to explore whether the contribution of the system to survival depended on factors that prolong delay between onset of OHCA and start of resuscitation. Modifying factors that were studied were: a) witnessed versus non-witnessed arrests; b) arrests at home versus arrests out of home; c) arrival time at the OHCA location of the first ambulance and d) whether the OHCA occurred during the day or during the evening/ night. The study population was the same as in chapter 2. Survival of 291 cases with out-ofhospital cardiac arrest where one or more volunteers attended (scenario 2) was compared with survival of 131 cases with out-of-hospital cardiac arrest where no volunteers attended and only standard care was given (scenario 1 ). The impact of the alert system on survival was higher in a) witnessed arrests $(\mathrm{OR}=2.25 ; 95 \% \mathrm{Cl} 1.27-4.00 ; P=.005)$ when compared with unwitnessed arrests $(\mathrm{OR}=0.64 ; 95 \% \mathrm{Cl} 0.10-4.05$; $P=.638)$; (b) arrests that occurred in the home $(\mathrm{OR}=2.28 ; 95 \% \mathrm{Cl} 1.21-4.28 ; P=.011)$ when compared to arrests outside the home $(\mathrm{OR}=1.36 ; 95 \% \mathrm{Cl} 0.47-3.89 ; P=.570)$; (c) arrests where the ambulance arrived with a delay of $7-10 \mathrm{~min}(\mathrm{OR}=2.63 ; 95 \% \mathrm{Cl} 1.09-6.35 ; P=.032)$ compared to arrival with a delay of $\leq 6$ minutes $(\mathrm{OR}=1.96 ; 95 \% \mathrm{Cl} 0.81-4.73 ; P=.137)$ or a delay of $\geq 11$ minutes $(\mathrm{OR}=1.29 ; 95 \% \mathrm{Cl}$ $0.39-4.31 ; P=.679)$; and (d) arrests at evening/night ( $\mathrm{OR}=3.07 ; 95 \% \mathrm{Cl} 1.34-7.03 ; P=.008)$ when compared with arrests at during daytime $(\mathrm{OR}=1.32 ; 95 \% \mathrm{Cl} 0.65-2.67 ; P=.441)$. $P$-values from tests for interaction were non-significant, probably due to low sample size.

The results show that survival gain due to the volunteer system is higher in resuscitation settings wherein volunteers can substantially shorten the delay between onset of OHCA and start of resuscitation. Evidently, in case of unwitnessed OHCAs volunteers cannot contribute much to improve survival as the prognosis is already poor from the beginning. Whether an OHCA is witnessed or not is related to the location of the cardiac arrest. OHCAs occurring outside the home have a higher probability of being witnessed and therefore being resuscitated by witnesses/bystanders before arrival of the emergency medical services (EMS). We found that OHCAs inside the home were less likely being witnessed and that CPR was started by a witness or bystander in only 50\%, implying that in the other half of OHCA victims the delay time until the start of resuscitation depends strongly on the arrival time of the EMS. This also explains why the alert system was most effective when the arrival time of the ambulance was between 6 and 11 minutes (44.5\% of the cases). These 6 to 11 minutes can be considered as the window of opportunity for the notified community responders. In this window their efforts have maximum effect on survival whereas at later arrival times of the ambulance this benefit decreases because professional care by ambulance personnel comes (too) late. Our study also suggested that gain in survival due to the system was more evident during the evening/night than during daytime. A possible explanation is a lower activation state of 
the dispatch/ambulance system and/or less availability of the ambulances in the evening/ night. The ambulance arrival times during the evening/night were longer compared to the ambulance arrival times during the day. During the evening/night 34.5\% of the ambulances arrived after 11 minutes whereas during the day $20.6 \%$ arrived after 11 minutes $(P=<.001)$.

\section{Chapter 4 Circumstances and causes of sudden circulatory arrests in the Dutch province of Limburg and the involvement of citizen rescuers}

Aim of the study was to verify whether the system was deployed in conditions for which it initially was developed by providing a description of the circumstances and causes of OHCAs, specifically were community responders are involved. During the 2-year study period 1546 OHCAs in the Dutch province of Limburg were recorded of which 461 victims with prolonged death; a resuscitation setting was present in 1085 cases including both cardiac and noncardiac arrests and cases with a do not resuscitate (DNR) policy. Within ambulance arrests $(n=32)$ and OHCAs occurring in closed public places with an on-site automated external defibrillator (AED) and local rescuers $(n=85)$ were excluded resulting in 968 OHCAs eligible for this study. The distribution of causes of OHCA, patient characteristics and resuscitation settings were compared between 492 arrests wherein volunteers were notified and 476 arrests where the dispatcher decided not to do so. The latter situation occurred frequently because the ambulance was already heading or present at the scene at the time the clinical situation of the patient deteriorated in a resuscitation setting.

In case of notification the cause of OHCA was identifiable in 345 cases and of cardiac origin (treatable) in $83.2 \%$ (287/345). About $41 \%$ of the cardiac arrests were caused by acute or chronic coronary artery disease. OHCA occurred within the home environment in about $84 \%$. The OHCA was witnessed in $75 \%$ of the cases. In $60.9 \%$ of the cases a witness or bystander had already started BLS. However, in approximately $18 \%$ of the OHCAs the volunteer was the first to start BLS before arrival of the ambulance. In about $75 \%$ of the OHCAs the ambulance arrived at 6 minutes or later after time of notification by the dispatch centre.

It is concluded that the alert system is predominantly activated in situations for which it was developed. Furthermore it was found that the majority of patients have no cardiovascular history, that it frequently regards cases with a cardiac cause $(83 \%)$ and cases in the home environment (84\%). The majority of patients encountered by the volunteers had 'hearts too good to die ${ }^{\prime 5}$, underscoring the benefit of deploying citizen rescuers in programs to improve survival of OHCA victims.

\section{Chapter 5 Characteristics of a novel citizen rescue system for out of hospital cardiac arrest in the Dutch province of Limburg. The relation to incidence and survival}

This study used the data from the registry to estimate the incidence of OHCA and to address questions such as: how often is the system activated in case of OHCAs and what were reasons 
to not activate the system; what is the mean notification rate per volunteer; is volunteer density related to survival?

Based on a total of 1546 OHCAs and prolonged deaths, crude incidence was 69 per 100,000 inhabitants per year, 94 per 100,000 men per year and 44 per 100,000 women per year. After standardisation for age with the European Standard Population (ESP), incidence was 67 per 100,000 inhabitants per year, 95 per 100,000 men per year and 39 per 100,000 women per year. In all age groups, the incidence rate of men was higher compared to women in agreement with previous studies ${ }^{1,6-10}$ where OHCA rates in men were 2 to 3 times higher. Also as expected, incidence peaked at the age group 70-79 years. To more accurately assess incidence we also included, in contrast to many studies ${ }^{2}$, cases who were found dead unexpectedly and without resuscitation effort.

During the 2-year study period about 9000 volunteers were registered, $60 \%$ being male, $59 \%$ with no experience in actual resuscitation and $27.4 \%$ being health care professionals. The system was not activated in 557/1085 (51.3\%) OHCAs, mostly because there was no resuscitation setting present at the moment of the emergency call or medical help was already at the location or close by. Another reason for not activating the system was absence of the zip code of the location of resuscitation. Rescuer notifications occurred in 1076 occasions, with no resuscitation setting being present in 548/1076 (50.9\%) cases. Community responders were notified at a mean rate of 1.3 times per year.

A positive relation was found between community responder density and percentage of survival to hospital discharge. If the density exceeded $0.75 \%$, survival increased to $34.8 \%$ compared to $20.6 \%$ at a density below $0.25 \%$. 


\section{References}

1. de Vreede-Swagemakers JJ, Gorgels AP, Dubois-Arbouw WI, et al. Out-of-hospital cardiac arrest in the 1990's: a population-based study in the Maastricht area on incidence, characteristics and survival. J Am Coll Cardiol. 1997;30:1500-5.

2. Berdowski J, Berg RA, Tijssen JG and Koster RW. Global incidences of out-of-hospital cardiac arrest and survival rates: Systematic review of 67 prospective studies. Resuscitation. 2010;81:1479-87.

3. Zipes DP and Wellens HJ. Sudden cardiac death. Circulation. 1998;98:2334-51.

4. van Swieten JC, Koudstaal PJ, Visser MC, Schouten HJ and van Gijn J. Interobserver agreement for the assessment of handicap in stroke patients. Stroke. 1988;19:604-7.

5. Beck CS and Leighninger DS. Hearts too good to die--our problem. Ohio State Med J. 1960;56:12213.

6. Chugh SS, Reinier K, Teodorescu C, et al. Epidemiology of sudden cardiac death: clinical and research implications. Prog Cardiovasc Dis. 2008;51:213-28.

7. Straus SM, Bleumink GS, Dieleman JP, van der Lei J, Stricker BH and Sturkenboom MC. The incidence of sudden cardiac death in the general population. J Clin Epidemiol. 2004;57:98-102.

8. Waalewijn RA, de Vos R and Koster RW. Out-of-hospital cardiac arrests in Amsterdam and its surrounding areas: results from the Amsterdam resuscitation study (ARREST) in 'Utstein' style. Resuscitation. 1998;38:157-67.

9. Kannel WB and Schatzkin A. Sudden death: lessons from subsets in population studies. J Am Coll Cardiol. 1985;5:141B-149B.

10. Kim C, Fahrenbruch CE, Cobb LA and Eisenberg MS. Out-of-hospital cardiac arrest in men and women. Circulation. 2001;104:2699-703. 


\section{Valorisation}

In industrialised countries sudden out-of-hospital circulatory arrest (OHCA) is an important public health problem ${ }^{1,2}$ largely caused by cardiac disease. ${ }^{3}$ Reported survival rates are low $(<10 \%)^{4,5}$ and have not improved significantly in many countries over the last 30 years. ${ }^{6}$ In this thesis we showed that the community responder system in the Netherlands is effective in increasing survival to hospital discharge in OHCA victims, that the degree of disability or dependence after survival is low (chapter 2) and that the contribution of the system to survival is most substantial in cases of witnessed arrest, in the home situation, at slightly delayed arrival of the first ambulance and during the evening/night (chapter 3). The majority of cases involving community responders had a cardiac cause and around $60 \%$ of the cases did not have a cardiovascular history. This implies a good prognosis after successful resuscitation and is referred to as patients with "hearts too good to die". It underscores the benefit of deploying community responders in programs to improve survival after OHCA (chapter 4). We also showed that the burden for community responders can be reduced because notification still carries a 50\% chance of resuscitation not being required. It is suggested that the effectiveness of the system could be further improved with a higher volunteer density (chapter 5).

\section{Number of lives to be saved}

The chapters of this thesis provide information allowing to estimate the number of lives potentially being saved by the system. As outlined in chapter 2, 422 cases with a (presumed) cardiac arrest were included in the two study years (mean 211/year). In case of notification of the system but without citizen rescuers attending survival was $16 \%(34)$. In contrast, $27 \%$ of OHCA victims (57) survived if at least one rescuer attended. This implies that, due to attendance of citizen rescuers, 23 more (57-34) OHCA victims can be saved yearly in the province of Limburg. When extrapolated, based on about 17 million Dutch inhabitants, nationwide 349 $(23 * 17 / 1.12)$ extra patients can be saved due to attendance of citizen rescuers.

This number is in accordance with estimations using data as reported by the Dutch Heart Foundation ${ }^{7}$ : the incidence of (presumed) cardiac resuscitations, EMS witnessed cardiac arrests excluded, is 37 per 100.000 per inhabitants per year. Assuming the Netherlands has around 17 million inhabitants, this accounts for 6290 (170*37) resuscitations per year of which reportedly $23 \%$ survive ${ }^{7}$ (1447). In our study we showed that the citizen rescue system was activated in half of all the cardiac arrests meaning that the system potentially could be activated in 3145 (6290/2) cardiac arrests per year nationwide. If the system is activated but no citizen rescuers attend the resuscitation $503(0.16 * 3145)$ cardiac arrest victims will survive in contrast to $849(0.27 * 3145)$ surviving if at least one rescuer attends. The attendance of citizen rescuers can therefore lead to 346 additional survivors nationwide which is in line with the previous mentioned extra survivors (349) based on our own data. 
Therefore, a relative increase in survival by $24 \%$ (346/1447) can be achieved if the response rate of citizen rescuers would be optimal (100\%). In our study, citizen rescuers responded in $67 \%$ of the 3145 notifications, which implies that survival gain could be achieved in 2107 cases. Activation of the system with no responders would lead to $337\left(0.16^{*} 2107\right)$ survivors compared to $568(0.27 * 2107)$ in case at least one rescuer attends the resuscitation resulting in 231 extra survivors nationwide. Therefore, in the current circumstances activation of the system could lead to $16 \%(231 / 1447)$ extra survival.

\section{Opportunities for improvement}

\section{Volunteer density and survival}

Based on our results on survival related to volunteer density per community it is tempting to speculate about the survival benefit that can be achieved when more volunteers will participate. As suggested in chapter 5 , survival rate increased with higher volunteer density. A volunteer density of 7.5 or more volunteers per 1000 inhabitants corresponds with a survival rate of $34.8 \%$ if at least one citizen rescuer attends the site of the cardiac arrest. Based on this estimate, 73 of the 211 OHCA cases per year would survive compared to 33 OHCA victims $(16 \%)$ if no citizen rescuers attend the resuscitation. Attendance of volunteers in communities with a volunteer density 7.5 or more volunteers per 1000 inhabitants results therefore in 40 (73 - 33) more survivors per year in the province of Limburg and 607 (40*17/1.12) nationwide. The observed increase in survival in communities with higher volunteer density can be explained by increased probability of rescuers being near the victim. Ideally, in every street of a neighbourhood rescuers should be available to help their neighbour to survive in case of a cardiac arrest.

\section{Increase of attendance of citizen rescuers}

Higher volunteer density is also likely to contribute to an increase in response rate of citizen rescuers. In our study it was found that in about one third of the system activations by the dispatcher no citizen rescuer attended. According to information from the rescuers management organization HartslagNu the number of rescuers is currently estimated to be 12.1 per 1000 inhabitants at the present time. Therefore it is likely that the attendance rate has increased with an expectedly concomitant increase in survival.

\section{The venue of a GPS based notification system}

During the study period a zip code based notification system was used. Where the system was static and bound to zip codes and time slots entered by citizens, in the meantime a dynamic system was developed based on the Global Positioning System. This implies that citizen rescuers are no longer bound to places (zip codes) but can be notified everywhere, close to the victim of a cardiac arrest. Clearly, continuous nationwide registries are needed to study the effectiveness of this and earlier mentioned improvements of the system. 


\section{Other possible fall outs related to the implementation of the rescuer system}

The introduction of the citizen rescuer system and its positive effects on outcomes have likely resulted in more awareness of OHCA in the general population. As a result possibly more cardiac arrests are recognised with early resuscitation attempts started by the witness(es) and earlier notification of the rescue services such as the EMS and the citizen rescue system. Possibly also more citizens are willing to obtain resuscitation skills and local and central governments are more likely to support CPR programs due to increased awareness. In this regard hopefully the Kids Saves Lives concept of the World Health Organisation, advocating CPR teaching programs in school will receive increasing attention. ${ }^{8}$

The development and national implementation of the citizen rescue system has led to an increase in public awareness about OHCA. Many citizens desire to contribute to society and a system such as the community responder system seems to allow them to do so. Moreover organising and maintaining the system within residencies may lead to more interaction and cohesion between citizens, likely contributing to improved quality of life within the communities. As such it fits well within the Healthy Cities concept of the World Health Organisation. ${ }^{9}$ 


\section{References}

1. de Vreede-Swagemakers JJ, Gorgels AP, Dubois-Arbouw WI, et al. Out-of-hospital cardiac arrest in the 1990's: a population-based study in the Maastricht area on incidence, characteristics and survival. J Am Coll Cardiol. 1997;30:1500-5.

2. Berdowski J, Berg RA, Tijssen JG and Koster RW. Global incidences of out-of-hospital cardiac arrest and survival rates: Systematic review of 67 prospective studies. Resuscitation. 2010;81:1479-87.

3. Zipes DP and Wellens HJ. Sudden cardiac death. Circulation. 1998;98:2334-51.

4. Waalewijn RA, de Vos R and Koster RW. Out-of-hospital cardiac arrests in Amsterdam and its surrounding areas: results from the Amsterdam resuscitation study (ARREST) in 'Utstein' style. Resuscitation. 1998;38:157-67.

5. Hasselqvist-Ax I, Riva G, Herlitz J, et al. Early cardiopulmonary resuscitation in out-of-hospital cardiac arrest. N Engl J Med. 2015;372:2307-15.

6. Sasson C, Rogers MA, Dahl J and Kellermann AL. Predictors of survival from out-of-hospital cardiac arrest: a systematic review and meta-analysis. Circ Cardiovasc Qual Outcomes. 2010;3:63-81.

7. Zijlstra JA, Radstok A, Pijls R, et al. Overleving na een reanimatie buiten het ziekenhuis: vergelijking van de resultaten van 6 verschillende Nederlandse regios Reanimatie in Nederland, 2016 Den Haag Nederlandse Hartstichting 2016.

8. Bottiger BW, Semeraro F and Wingen S. "Kids Save Lives": Educating Schoolchildren in Cardiopulmonary Resuscitation Is a Civic Duty That Needs Support for Implementation. J Am Heart Assoc. 2017;6.

9. Green $\mathrm{G}$, Jackisch J and Zamaro G. Healthy cities as catalysts for caring and supportive environments. Health Promot Int. 2015;30 Suppl 1:i99-i107. 


\section{Dankwoord}

Allereerst wil ik mijn promotieteam bedanken. Zonder jullie kritische blik en oneindig geduld was dit proefschrift nooit tot stand gekomen. Het was geen makkelijke weg die we afgelegd hebben maar ik vind dat we als team trots mogen zijn op dit resultaat.

Ton, je hebt een duidelijke missie en visie als het gaat om reanimaties en reanimatieonderwijs en je bespaart moeite noch tijd om je hiervoor in te zetten. Ik heb dat altijd erg bijzonder gevonden. Je bent een inspiratiebron voor velen. Ik wil je graag bedanken voor de begeleiding tijdens dit promotietraject en het vertrouwen dat je mij gaf.

Patty, je expertise en begeleiding waren onmisbaar tijdens dit traject. Door jouw vasthoudendheid bleven we grasduinen en zijn we enorm de diepte ingegaan waarvan ik veel geleerd heb. Uiteindelijk kwam altijd de onderste steen boven. Soms leidde dit tot juist meer vragen, maar ook die konden we uit eigenlijk beantwoorden. Ook jou wil ik graag bedanken voor je begeleiding (en luisterend oor) en vertrouwen.

Naast het promotieteam wil ik Braim bedanken voor zijn oprechte interesse in en feedback op alle publicaties. Braim, je feedback was altijd heel helder en constructief, dank daarvoor!

Ook wil ik iedereen in de participerende ziekenhuizen bedanken die zich, in welke vorm dan ook, hebben ingezet voor dit proefschrift.

Er zijn veel instanties, bedrijven en organisaties die de onderzoeken in dit proefschrift hebben mogelijk gemaakt. Zonder jullie bijdrage was dit proefschrift nooit tot stand gekomen. Dank daarvoor!

Tijdens de fase van dataverzameling zijn er een aantal studenten geweest die geholpen hebben met onder andere het verzamelen van data en deze overzetten naar een database. Deze studenten wil ik graag bedanken voor hun tijd en inzet.

Daarnaast wil ik mijn vrienden en familie bedanken voor de steun tijdens dit gehele promotietraject.

Ook wil ik alle vrijwilligers in het burgerhulpsysteem bedanken voor de onbaatzuchtige inzet tijdens reanimaties. Jullie redden letterlijk levens!

Het is onmogelijk om iedereen persoonlijk te benoemen, daarom wil ik ledereen die betrokken is geweest bij de totstandkoming van dit proefschrift bedanken. 
Als laatste wil mij richten tot mijn gezin te beginnen bij mijn lieve vrouw Lianne. Lianne, toen wij elkaar leerden kennen dacht ik bijna klaar te zijn met mijn promotieonderzoek. Dat was 5 jaar geleden....... Je bent in die 5 jaar mijn steun en toeverlaat geweest. Het pad dat ik moest bewandelen om tot hier te komen was niet altijd makkelijk; er waren mooie maar ook zeker moeilijke momenten. De afgelopen 5 jaar ben je er altijd voor mij geweest en liet je me vaak inzien dat de weg naar een doel belangrijker is dan het doel zelf. Je bent een ongelofelijk sterke vrouw en met jou aan mijn zijde kan ik alles aan!

Siem en Isa, mijn twee boefjes. Jullie betekenen zoveel voor mij dat kan ik niet eens met een pen beschrijven. Pappa is nu klaar met zijn boekje en heeft vanaf nu nog meer tijd om jullie te PAKKEN! 


\section{About the author}

Ruud Pijls was born in Roermond (The Netherlands) on the $27^{\text {th }}$ of January 1985. He grew up in a small town (Roggel) in the middle of the province Limburg and went to secondary school in Horn (SG. St. Ursula) were he completed Atheneum in 2003. After his secondary school he served the army for one year. In 2004 he started to study Health Sciences at Maastricht University were he obtained his bachelor degree in 2007 followed by the Public Health master Health Policy Economics and Management in 2008 and the master European Public Health in 2010. In that same year he started his PhD trajectory at the Maastricht University school Care and Public Health Research Institue (CAPRHI).

Ruud lives together with his wife Lianne and their son Siem (3) and daughter Isa (1). 


\section{List of publications}

- Sharma AS, Pijls RW, Weerwind PW, Delnoij TS, de Jong WC, Gorgels AP and Maessen JG. Out-of-hospital cardiac arrest: the prospect of E-CPR in the Maastricht region. Neth Heart J. 2016;24:120-6

- Mak M, Moulaert VR, Pijls RW and Verbunt JA. Measuring outcome after cardiac arrest: construct validity of Cerebral Performance Category. Resuscitation. 2016;100:6-10

- Grasner JT, Lefering R, Koster RW, Masterson S, Bottiger BW, Herlitz J, Wnent J, Tjelmeland IB, Ortiz FR, Maurer H, Baubin M, Mols P, Hadzibegovic I, loannides M, Skulec R, Wissenberg M, Salo A, Hubert H, Nikolaou NI, Loczi G, Svavarsdottir H, Semeraro F, Wright PJ, Clarens C, Pijls R, Cebula G, Correia VG, Cimpoesu D, Raffay V, Trenkler S, Markota A, Stromsoe A, Burkart R, Perkins GD, Bossaert LL and EuReCa ONEC. EuReCa ONE-27 Nations, ONE Europe, ONE Registry: A prospective one month analysis of out-of-hospital cardiac arrest outcomes in 27 countries in Europe. Resuscitation. 2016;105:188-95

- Pijls RW, Nelemans PJ, Rahel BM and Gorgels AP. A text message alert system for trained volunteers improves out-of-hospital cardiac arrest survival. Resuscitation. 2016;105:182-7

- Zijlstra JA, Radstok A, Pijls R, Nas J, Beesems SG, Hulleman M, Lichtveld RA, Hoekstra ACl, Brouwer MA, Gorgels AP, Van der Heijden JJ, Koster RW and Blom MT. Overleving na een reanimatie buiten het ziekenhuis: vergelijking van de resultaten van 6 verschillende Nederlandse regios Reanimatie in Nederland, 2016 Den Haag Nederlandse Hartstichting 2016

- Hulleman M, Nas J, Pijls R, Stieglis R, Radstok A, Lichtveld R, Hoekstra I, Zijlstra J, Beesems $\mathrm{S}$, Van der Heijden J, Gorgels AP, Koster R, Brouwer M and Blom T. Afname van de proportie schokbare beginritmes bij reanimaties buiten het ziekenhuis in Nederland Reanimatie in Nederland, 2016 Den Haag: Nederlandse Hartstichting 2016

- Zijlstra JA, Pijls R, Veldhuijzen A, Blom MT, Koster RW and Gorgels AP. De rol van de burgerhulpverlener in de keten van overleving in Noord-Holland Noord \& Twente en in de provincie Limburg Reanimatie in Nederland, 2016 Den Haag: Nederlandse Hartstichting; 2016

- Pijls RW, Nelemans PJ, Rahel BM and Gorgels AP. Factors modifying performance of a novel citizen text message alert system in improving survival of out-of-hospital cardiac arrest. Eur Heart J Acute Cardiovasc Care. 2017:2048872617694675 
- Pijls RWM, Nelemans PJ, Rahel BM and Gorgels APM. Circumstances and causes of sudden circulatory arrests in the Dutch province of Limburg and the involvement of citizen rescuers. Neth Heart J. 2018;26:41-48

- Pijls RWM, Nelemans PJ, Rahel BM and Gorgels APM. Characteristics of a novel citizen rescue system for out-of-hospital cardiac arrest in the Dutch province of Limburg: relation to incidence and survival. Neth Heart J. 2019;27:100-107 



\title{
THE CONTRIBUTION OF CITIZEN RESCUERS TO SURVIVAL AFTER
}

\begin{abstract}
OUT-OF-HOSPTAL CARDIAC ARREST
\end{abstract}

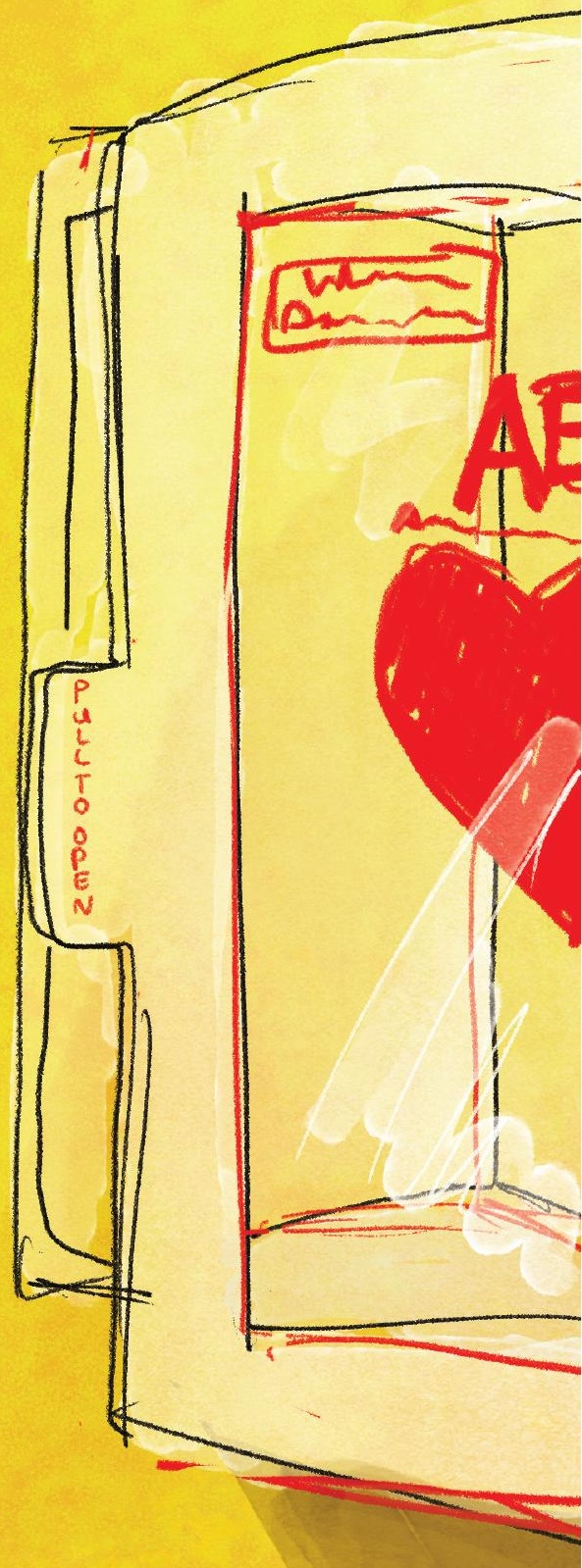

Dit proefschrift is opgedragen aan alle slachtoffers van een plotselinge hartstilstand buiten het ziekenhuis en alle burgerhulpverleners die zich inzetten voor de medemens. 